\title{
مشاهد الثيران والأبقار المشاركة في الموكب الجنائزي من الدولة القديمة حتى نهاية الدولة الحديثة
}

\section{Scenes of Oxen and Cows Participating in the Funeral Procession from the Old Kingdom to the End of the New Kingdom}

\author{
محمد البيومي محمد البيومي \\ أستاذ الآثار المصرية القديمة المساعد بقسم الآثار - كلية الآداب - جامعة طنطا
}

\section{Mohamed Elbayoumi Mohamed}

Assistant professor of Egyptology department of Archaeology-Faculty of Arts-Tanta University.

mohmed.sch@gmail.com

الملخص:

شاركت الماشية في الموكب الجنائزي سواء كانت ثيران أو بقرات، حيث أدت دوراً محورياً في الموكب، من خلد

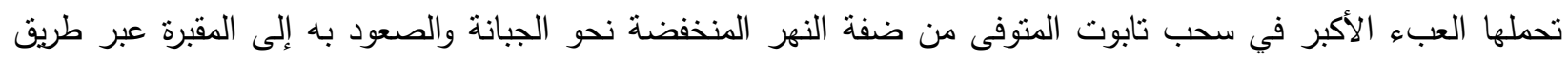

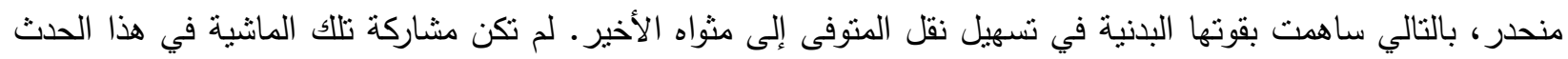

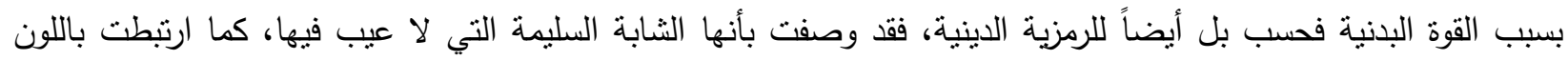

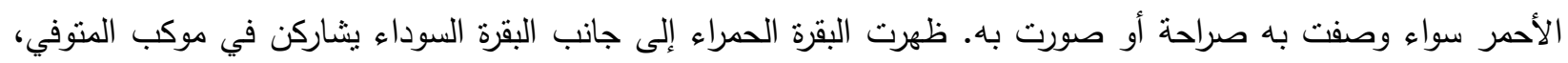

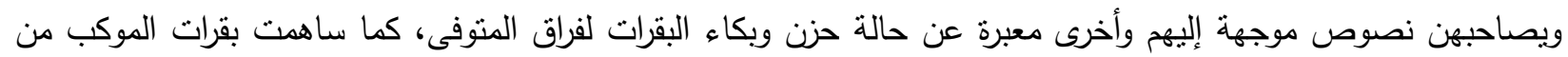

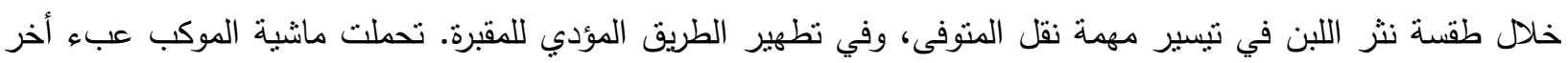
أكثر أهمية إلى جانب سحب الموكب. هكذا يتتاول البحث تلك المرحلة الحاسمة والدقيقة من مراحل الموكب الجنائزي والتي فئي أدت فيها ماثية الموكب أدواراً هامة وحاسمة في نقل وإحياء المتوفى من خلال مشاهد أغلبها مصور على جدران مقابر ملى ملى الأشراف من الدولة القديمة حتى نهاية الدولة الحديثة.

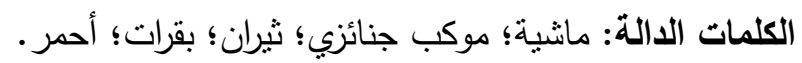

\section{Abstract:}

Cattle that participated in the funeral procession, whether bulls or cows, played an important role in the procession by bearing the greatest burden in pulling the deceased's coffin from the lowest river bank towards the necropolis and ascending it to the tomb through a steep road, thus they had contributed by their physical strength to facilitate the transport of the deceased to his lasting place. The participation of cattle in this event was due to physical strength, and religious symbolism, the procession's cattle were described as healthy, strong and young. In addition cattle had associated with the red color, whether explicitly described or depicted. The red cow appeared next to the black cow in the procession of the deceased, accompanied by texts addressed to them, and other texts were expressing a state of sadness and crying for the deceased. The procession's cows contributed; through the ritual of milk scattering to facilitate the mission of transporting the deceased and purifying the road to the tomb. The procession's cattle had another important role besides the dragging of the procession. Thus, the research studies the critical stage of the funeral procession, in which the procession's cattle played important and decisive roles in transporting and resurrection of the deceased, through scenes, most of which are depicted on the walls of the noble tombs from the Old Kingdom until the end of the New Kingdom. 
Keywords: Cattle, Funeral procession, oxen, cows, red.

يمر الموكب الجنائزي بثلاث مراحل: تبدأ رحلته من المنزل إلى النهر، ثم عبور النهر، ثم تتتهي رحلة الموكب بالمسير من النهر إلى القبر'، حيث إنه بمجرد أن ترسو المراكب على البر الغربي للنهر، فإنه يوضع تابوت المتوفى على زحافة تجرها الماشية، وتعد هذه المرحلة جزءاً مهمًا من الموكب الجنائزي وقد صُور في العديد من المقابر ، خاصة مقابر الدولة الحديثةُ ـ. أطلق المصريون على الثور البري المتواجد في منطقة مستتقعات الدلتا والتالال المتاخمة للوادي اسم ng، حيث صور ببدن نحيف وقرون واسعة طويلة تماتل قرون ثثران lw3، وكان يتم اقتتاص الثور بالحبال، وبمجرد ترويضه يُسمح له بالرعي بحرية حيث يقاد للخدمة بواسطة عصي أو حبال، وبعد هذا النوع من الثيران حيوان جر بامنياز، حيث استخدم في جر المحراث والكتل الحجرية والتوابيت في المواكب الجنائزية، أما الثور lW3 فتميز بأنه سمين له بطن متدلية، وساقيه أقصر من سيقان ng، وتشير النصوص إلى أن أصله من الجنوب وكان يسمن بطريقة منظمة لغرض الذبح ،وكان هذا النوع مفضل في التضحية حيث يقدم كقربان، وللثثرين ng و iw3 إناث استخدموا في الحلب كما استخدموا كحيوانات للتضحية تذبح وتقدم لحومها في شعائر الخدمة الجنائزبية'.

تتوعت المفردات المرتبطة بثيران وبقرات الموكب الجنائزي، وكان أكثرها شيوعاً وارتباطاً بالصفات البدنية ng و iw3z، كما استخدمت بعض المفردات لتحديد الجنس مثل k3 للتور و iht للبقرة، واستخدمت كلمة mrt بمعنى "بقرة سوداء"، كذللك وردت كلمة nfrt "جميلة" للالالة على مظهر البقرة . يغلب على الثيران المشاركة في الموكب الجنائزي اللون الأحمر، وأحياناً تشارك في الموكب بقرات حمراء وأخرى سوداء، ولم تشارك تلك البقرات فقط في سحب تابوت المتوفي، ولكن أيضاً من خلال لبنها، ومشاعر الحزن والنواح والبكاء تلك المشاعر التي نقلتها النصوص المصاحبة لمشاهد تلك البقرات؛ لذا ربط البعض بينها وبين النادبتين إيزة ونبت-حت .

${ }^{1}$ WILSON, J. A.: «Funeral Services of the Egyptian Old kingdom», JNES 3, 1944, 203, 205, 210;

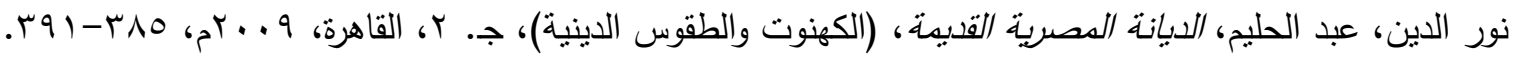
2 GoMEZ, G. M.: «La Procesión Funeraria de la Tumba de Hery (TT 12) en Dra Abu el-Naga», BAEDE 15, $2005,44$.

${ }^{3}$ SMITH, H. S.: "Animal Domestication and Animal Cult in Dynastic Egypt", In The Domestication and Exploitation of Plants and Animals, 307-314, New York, 2017, 308; STÖRK, L.: “Rind”, in L̈̈, V, 258.

${ }^{4}$ STÖRK, Rind, $L \ddot{A}, \mathrm{~V}, 258$.

${ }^{5}$ LeITZ, C., Lexikon der Ägyptischen Götter und Götterbezeichnungen, VII, Belgium, 2002, 574; GuILHOU, N.: «La Mutilation Rituelle de Veau dans le Scènes de Funérailles au Nouvel Empire», BIFAO 93, 1993, 294. 
وسوف يتتاول البحث مشاهد الثيران الششاركة في الموكب الجنائزي والتي وصفت بـ rكّا الحمراء، أو

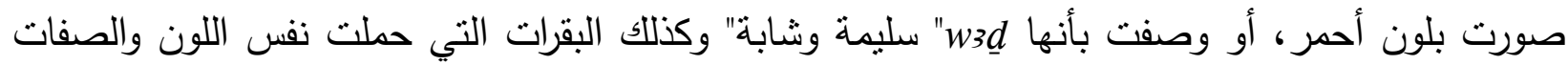
إلى جانب البقرات السوداء، ويوضح البحث الجوانب المتعددة لمشاركة تلاك الماشية في الموكب الجنائزي. يعرض البحث مدي تأثثر التباين المادي والاجتماعي بين الأفراد على مشاهد ثثران وأبقار الموكب

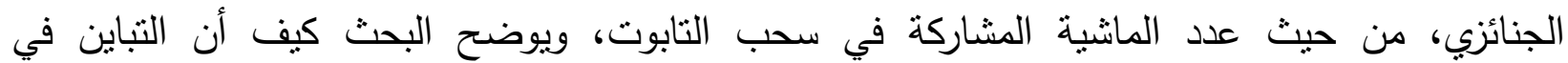

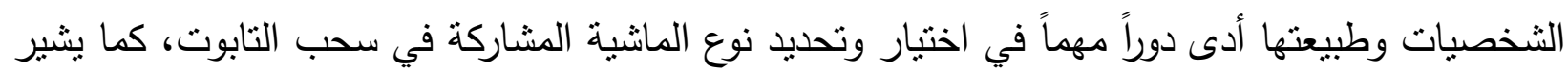
البحث إلى شخصيات وثيقة الصلة بثيران وأبقار الموكب الجنائزي. 1 ا ـ مشاهل مشاركة الثيران في الموكب الجنائزي 1, إخبرة حتب- حر - آخت":

يوجد بالممر الأول (A) الجدار الثمالي (e) الصف الثالث (ثكل () منظر يمثل مقصورة مفتوحة بداخلها تمثال، يقق فوق زحافة يجرها ثيران حمراء، وأمام التمثال رجل يقدم البخور، خلفه الكاهن المرتل

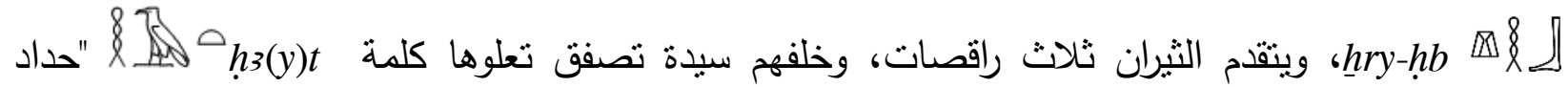

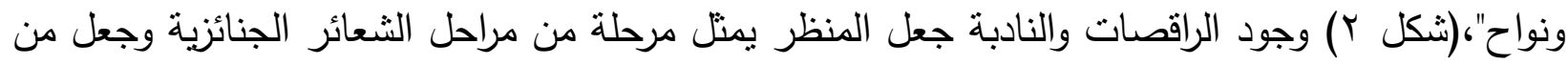

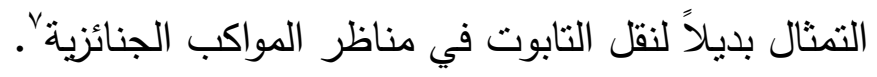

" تضم نقوش المقبرة خرطوش الملك نفراير -كا-رع وبالتالي ترجع لعصر الأسرة الخامسة، تم اكتثاف مقصورة المقبرة في

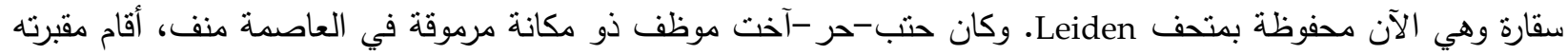
في سقارة بالقرب من العاصمة، نال حتب-حر -آخت ألقاب أهمها: ssmsw h3yt, hm-ntr M3' القضاء، كاهن ماعت"، ويلاحظ أن ألقابه القضائية ذات علاقة قوية بلقبه الكهنوتي، مما برجح أنه شغل منصب الكاهن الأكبر

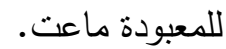
MOHR, H. T., The Mastaba of Hetep-her-akhti, Leiden, 1943 ,3, 27; MASPERO, G., Les Mastabas de L'Ancien Empire, Paris, 1889, 340, 347.

7 MOHR, The Mastaba of Hetep-her-akhti, 37-39; EATON-KRAUSS, M., The Representations of Statuary in Private Tombs of the Old kingdom, Wiesbaden, 1984, 65, FIG.78; WILSON, Funeral Services, 211; FORSHAW, R., The Role of the Lector (hry-hbt) in Ancient Egyptian Society, Manchester, 2013, 243. 
النص فوق التمثال يضم ألقاب المتوفى واسمه:

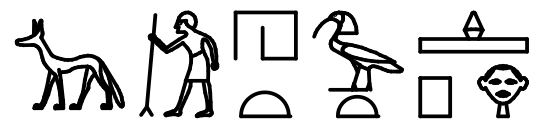

sзb smsw hзyt Htp-ḥr-3ht

" القاضي، كبير قاعة القضاء؛، حتب-حر -آخت".

يعلو الثورين العبارة التالية:

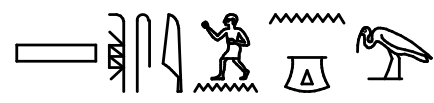

šms in $n g$ ď̌r

" مصحوباً بالثور الأحمر" ".

يلاحظ أن المنظر يصور ثورين عبر عنهما النص بصيغة المفرد، إذ ربما أراد الفنان التعبير عن وحدة الاتجاه والهدف والقوة والمصبر باستخدام صيغة المفرد '.

ظهر أيضاً على الجدار الثمالي أعلى مدخل مقبرة إيدو رقم G7102 بجبانة الجيزة منظر يمنل موكباً جنائزيًّا، حيث وضع التابوت فوق زحافة يجرها رجال وزوج من الثيران طويلة القرون، كما تكرر المنظر في مقبرة بتاح -حتب الثاني في سقارة" .

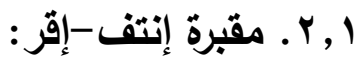

صور نقل التابوت في مقبرة Intf-Ilk رقم •T بجبانة شيخ عبد القرنة على الجدار الجنوبي للممر (شكل r)، وقد شغل إنتف-إقر منصب الوزير والقاضي في عهد سنوسرت الأول، ويمثل المنظر تابوت بشري وضع فوق زحافة يحيط به كل من إيزة ونبت-حت والكاهن المرثل، والمحنط، وحامل الختم المقد،

smsw h3yt “ مخصصات كلمة h3yt حيث كتبت بمخصص - ‘كما وردت بمخصص ح، ويمثل عصا قصيرة تلك العصا نظهر في كلمة

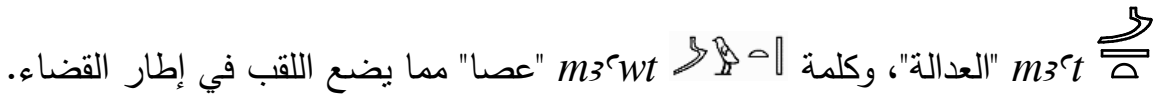

FISCHER, H. G., Egyptian Studies III, Varia Nova, New York, 1996, 227-230; JONES, D., An Index of Ancient Egyptian Titles, Epithets, and Phrases of the Old kingdom, I, Oxford, 2000, 902,903; Wb. II, 476, 8-11.

${ }^{9}$ MOHR, The Mastaba of Hetep-her-akhti, 38; WILSON, Funeral Services, 211; MASPERO, Les Mastabas, 343. ·' أنظر (شكل · ب) ذبح الثيران الحمراء- مقبرة مونتو -حر -خبش.إف - جبانة ذراع أبو النجا وكذلك انظر النتائج. ${ }^{11}$ HASSAN, S., Excavations at Giza 1932-1933, IV, Cairo, 1943, 75; SIMPSON, W. K., The Mastabas of Qar and Idu G7101 and 7102, Boston, 1976, 21, 22, PL. XVIII, FIG.35; SETTGAST, J., Untersuchungen zu den Altägyptischen Bestattungsdarstellungen, New York, 1963, PL.I. 
وكاهن الكا، وكاهن سم، وأربعة رجال يمتلون المدن المقسةج' ويتقام الموكب ثوران، (شكل عأ، ب) ويعلو الموكب نص ينتهي عند الكاهن المرتل الواقف بجوار التابوت، حيث يثير بيده ليتقدم الموكب ويعلو يدهاه

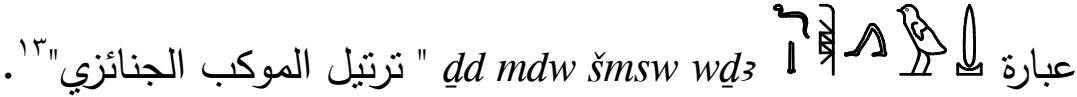
يعلو ثبران الموكب:

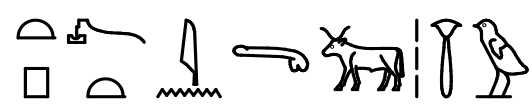

(ms)tpt ${ }^{14}$ in $k 3 w w 3 \underline{d} w$

$$
\text { "(سحب) زحافة التنابوت بواسطة ثيران شابة "هُ. }
$$

وردت هذه العبارة بشكل كامل في مقبرة إنني "1 رقم اN بجبانة شيخ عبد القرنة في منظر لسحب التابوت بالثيران:

\section{-}

sta 3 hr mstpt in $k 3 w$ ws $\underline{d} w$

$$
\text { "سحب زحافة التابوت بواسطة ثيران شابة"VI". }
$$

r' عرف هؤلاء الرجال باسم smrw psd " الأصدقاء التسعة" و هم يمثلون الأثباع ويرمزون إلى المدن المقدسة مثل بونو وأبو

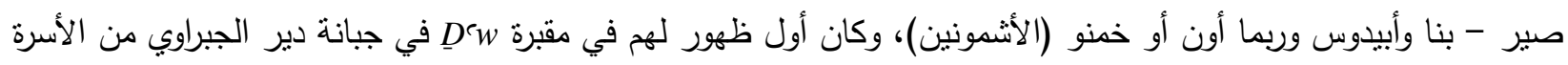
السادسة، ثم ظهروا في مقبرة إنتق - إقر من الدولة الوسطى واستمر ظهورهم في مناظر الموكب الجنائزي خلال الدولة الحديثة، وأحياناً يظهرون مجتمعين أو يمثلون بأي عدد منهم، وشمل دورهم صناعة التابوت ووضعه على على الزحافة وسحبها

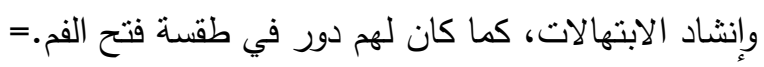

$=W b$. IV, 139, 4; DAVIES, N. G., The Rock Tombs of Deir El Gabrawi, II, London, 1902, PL.VII; EL-SHAHAWY, A., The Funerary Art of Ancient Egypt, a Bridge to the Realm of the Hereafter, Cairo, 2006, 41; DAVIES, N. G., The Tomb of Antefoker Vizer of Sesostris I and of his Wife Senet №.60, London, 1920, 21, PL.XXI; TEETER, E., Religion and Ritual in Ancient Egypt, New York, 2011, 138.

${ }^{13}$ DAVIES, The Tomb of Antefoker, 12 note 3, 21, PLS.XXII, XXIII; STEVENS, J., Le Tekenou et son Implication dans les Rites Funéraires de l'Égypte Ancienne, Louvain, 2020, 20; PM.I,121.

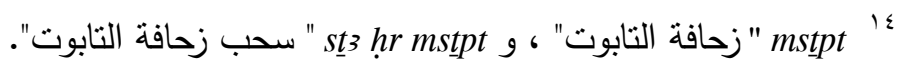

Wb. II, 152, 9.

15 LÜDDECKENS, E.: «Untersuchungen über Religiösen Gehalt, Sprache und form der Ägyptischen Totenklagen», MDAIAK 11, 1943, 29.

17 حمل "إنني" لقب h3sty- imy-r šnwty n Imn" العددة، مشرف شونتي أمون"، من عهد أمنحتب الأول إلى تحتمس

الثالث، وكان من عائلة مرموقة حيث حمل أبيه لقب s3b" قاضي"، وحملت أمه لقب

DZIOBEK, E., Das Grab des Ineni Theben №.81, Mainz, 1992, 41, 55, 66, 141.

${ }^{17}$ DZIOBEK, Das Grab des Ineni, 78, TAF.27; LÜDDECKENS, Untersuchungen über Religiösen Gehalt, 29. 
جدير بالذكر أن اختيار ثيران شابة قوية وفتية تنتاسب وتلك المهمة الثناقة المكلفة بها أثتاء المشاركة

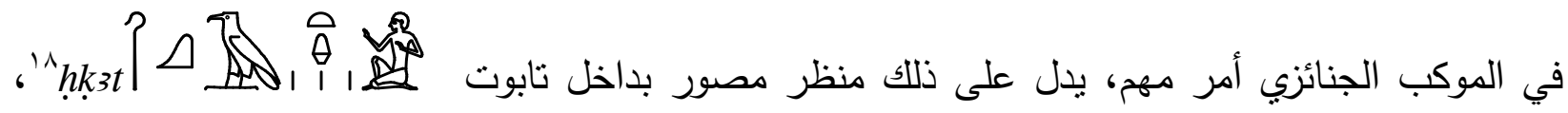
(شكل 0)، حيث يوجد منظر نادراً ما يصور على توابيت الدولة الوسطى، يمنل موكباً جنائزياً مكون من ثمانية رجال وثورين بسحبون زحافة تحمل تابوت إلى المقبرة، وأمام الزحافة مباشرة يوجد رجل يشير بيده ليوجه حركة الموكب بما يماتل مشهد الكاهن المرتل في موكب تابوت إنتف-إقر 9.

يعلو الموكب نص مكتوب بالخط الهيراطيقي يشير إلى سحب التابوت بواسطة رجال الفنتين والنبلاء

$$
\text { والعامة وثورين عبر عنهما النص بـ ngwy wz }
$$

ظهر في الصف العلوي للجدار الغربي بصالة المقبرة (شكل ؟) منظر زحافة يسحبها ثيران ورجال في سياق موكب جنائزي، وقد ثبت حبل الزحافة في قرون الثيران، التي يحثها قائدها على مواصلة المسير من

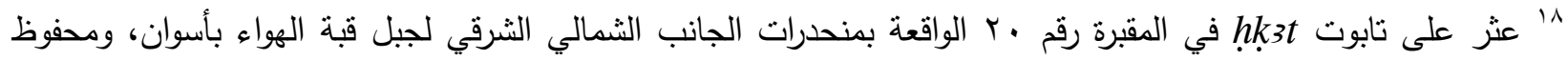

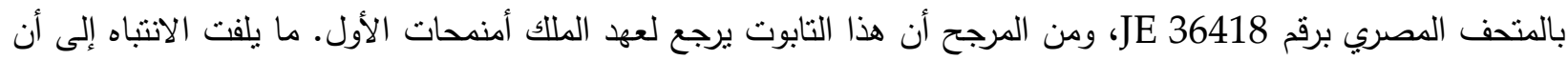

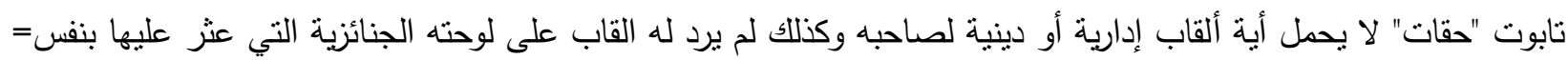

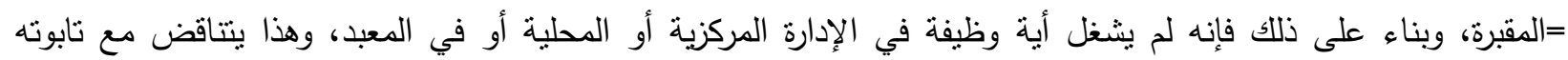
المزخرف عالي الجودة؛ لذا من المرجح أنه كان صاحب مكانة رفيعة بلغها بثرائه الكبير • Willems, H., The Coffin of Heqata (Cairo JdE 36418), Louvain, 1996, 15, 22; JiMÉNEZ-SERRANO, A \& Morales, A. J.: Middle Kingdom Palace Culture and its Echoes in the Provinces Regional Perspectives and Realities, Leiden, 2021, 223.

${ }^{19}$ WILLEMS, The Coffin of Heqata, 233, 235; GóMEZ, La Procesión Funeraria, 46.

${ }^{20}$ WILLEMS, The Coffin of Heqata, 235, note 1267.

"r مقبرة "با-حري" رقم (r) في جبانة الكاب، التي توجد جنوب طيبة بنحو خمسين كيلو متر، وهي إحدى ضواحي العاصمة نخن عاصمة الإقليم الثالث من أقاليم مصر العليا، وكان با-حري عمدة مدينتي نخب وأيونيت خلال الأسرة الثامنة عشرة في فئري عهد الملك تحتمس الثالث. ينتمي "باحري" إلى عائلة شهيرة وثرية حيث كان جده القائد الثهير أحمس ابن أبانا الذي حارب في في

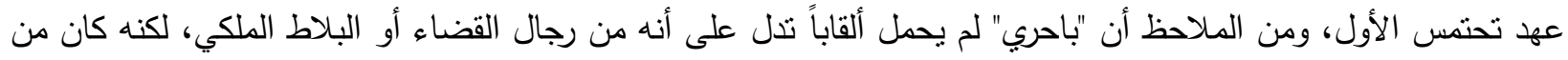
الأثرياء وكانت له أعماله المالية الخاصة، بجدئن ومن بعض المهام المكلف بها من قبل الملك، حيث نالوا ألقاباً بسيطة مثل العمدة والنبيل، كما نال لقب الكاتب محصي الحبوب، والمشرف على أراضي الحبوب في الجنوب، وحمل لقب كهنوتي حيث كان كبير كهنة المعبودة نخبت.

TYLoR, J. \& GRIFFITH, F.: The Tomb of Paheri at el Kab, London, 1894, 5-7; PM. V, 177; STEVENS, Le Tekenou et son Implication, 38;

جيمز، ت. ج.، الحباة أيام الفراعنة، (مشا هد من الحباة اليومية في مصر القديمة)، ترجمة، أحمد زهير أمين، القاهرة، 99 19 
خلال الإشارة بإحدى يديه ومن خلال سوط بيده الأخرى، وبساعد الثيران في سحب الحبل أربعة رجال، ويتقدهم ثلاثة منشدين رافعين أيديهم(شكل V أ،ب)،كما يوجد بين رجال سحب الحبل رجل يحرق البخور، وتحمل الزحافة تابوت بعلوه سرير مزخرف وفوقه تسنقر المومياء، ويلاحظ أمام التابوت مباشرة سيدة تحمل لقب drt-šrt " النادبة الصغيرة" وتجسد المعبودة نبت-حت، بينما يلي التابوت مباشرة سيدة أخرى تحمل لقب drt-e $3 t$

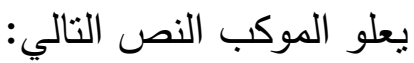

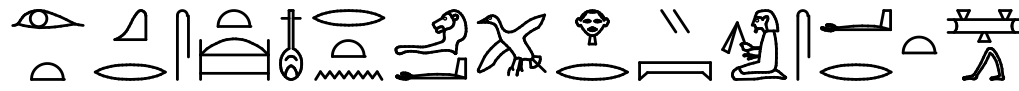

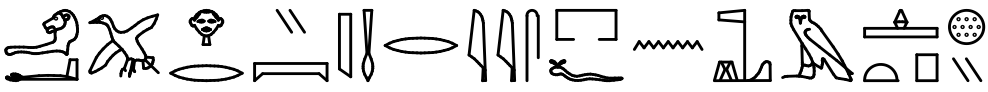

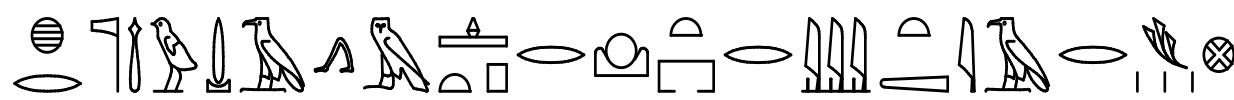

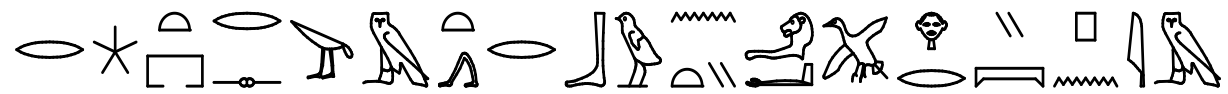

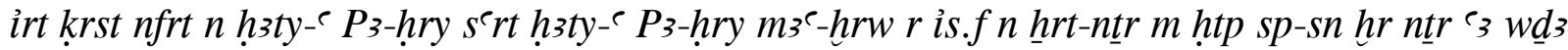
$m$ htp $r$ зht $r$ sht ỉsrw $r$ dwst $r$ sšmt $r$ bw nty häty-e P3-hry pn im

"عمل دفنة طيبة للعمدة بـا-حري، حيث صعود العمدة بـا-حري صـادق الصسوت إلى مقبرتهـ في الجبانة بسـلام بسـلام لدي المعبود العظيم، حيث التقدم بسـلام نحو الأفق ونحو حقول الغـاب ونحو العالم السفلي

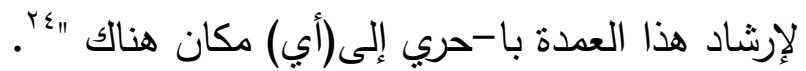

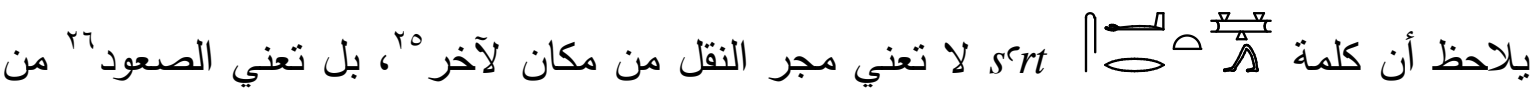
r ntr r 3ht.f

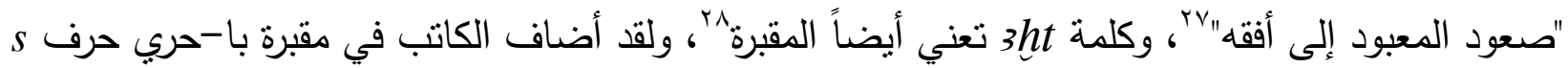

22 TYLOR, J. \& GRIFFITH, F., The Tomb of Paheri, 19.

rr وردت كلمة si في النص بمضاعفة حرف i فيبدو أن هناك خطأ من الكاتب حيث خلط بين حرف i وبين لفافة البردي

Wb. I, 126, 18.

ใी

24 TYLOR, J. \& GRIFFITH, F., The Tomb of Paheri, 20, PL.V.

25 TYLOR, J. \& GRIFFITH, F., The Tomb of Paheri, 20.

${ }^{26}$ FAULKNER, R. O., A Concise Dictionary of Middle Egyptian, Oxford, 1991, 45.

${ }^{27}$ LÜDDECKENS, Untersuchungen über Religiösen Gehalt, 57; SETHE, K., Agyptische Lesestucke Texte der Mittleren Rreiches, Leiptzig, 1959, 3; LICHTHEIM, M., Ancient Egyptian Literature, I, London, 1973, 223.

${ }^{28}$ FAULKNER, A Concise Dictionary, 5. 
لكلمة re للدلالة على مشقة الصعود واجتياز الطريق المرتفع من النهر إلى المقبرة، مما يفسر ضرورة تواجد الثيران والقائد الذي يحث الثثران بسوطه على التقدم والرجال الذين يعاونون الثيران في سحب الحبال.

\section{ا , \& ـ مقبرة مونتو -حر -خبش.إف:}

يوجد منظر مهم يعكس مشاركة الثيران في الموكب الجنائزي على الجدار الجنوبي للحجرة الداخلية بالمقبرة TT20 بجبانة ذراع أبو النجا(ثكل ^)، والتي تخص مونتو -حر -خبش.إف حامل المروحةَ من عهد الملك تحتمس الثالث، يصور أول مشاهد الموكب الجنائزي ثلاثة من أقارب المتوفى ربما أبناؤه يتبعهم

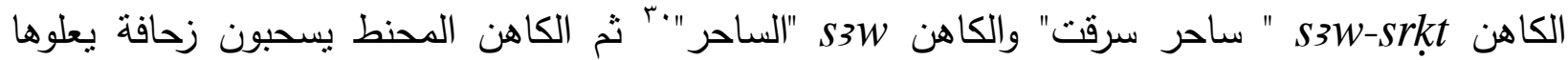
التكنو ‘ّ بشكل رجل ساجد بدون غطاء أو كفن(شكل 9)، وخلف التكنو أربعة رجال يسحبون ناووس يتبعهم الكاهن المرتل، بعلو فريق سحب الناووس كلمة mrht "زبوت"، وفوق إفربز الناووس صيغة القربان النالية :

$\underline{t 3 y-h w ~ n ~ p r: ~: ~}$

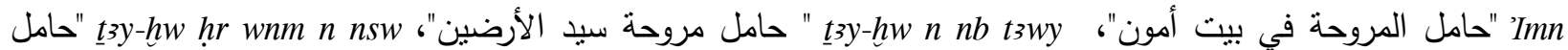

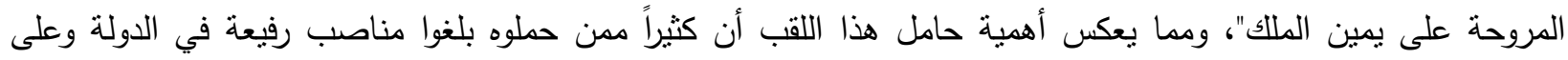
رأسهم وزراء. بالإضافة إلى ذلك حمل "مونتو -حر -خبش.إف" لقب حامل الختم الملكي وكذلك المشرف على على الكهنة. MASPERO, G.: «Le Tombeau de Montouhikhopshouf», MMAF 5, 1894, 436; AL-AYEDI, A. R., Index of Egyptian Administrative, Religious and Military Titles of the New Kingdom, Ismailia, 2006, 649-654.

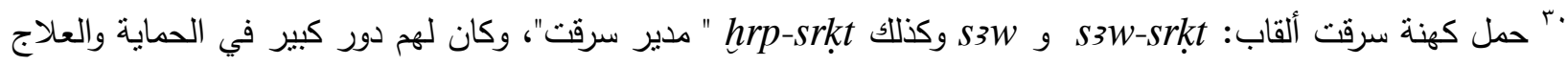
من لدغات الثعابين والعقارب التي تكثر في المناطق الصحراوية وتهدد حياة العاملين بالمناجم والمحاجر ، وبالتالي وردت ألقابهر ضمن أفراد البعثات في سيناء ووادي الحمامات، كما أدوا نفس الدور في الجبانة حيث تتم شعائر الدفن. FORSHAW, The Role of the Lector (hry-hbt), 291, 314, 319; HELCK, W., Untersuchungen zu den Beamtentiteln des Agyptischen Alten Reiches, New York, 1954, 67; AltenMUlLER, H.: «Bestattungsritual», LÄ, 1, 758; JONES, An Index of Ancient Egyptian Titles, 802.

ا" التكنو عبارة عن وعاء من الجلا يظهر أحياناً بلا معالم محددة وأحياناً يضاف له رأس بشرية، ومن المعثقل أنه يحتوي المواد المتخلفة عن عملية التحنيط والمختلطة بأنسجة أعضاء الجسد المحنط، والتي يصعب وضعها في الأواني الكانوبية أو دفنها مع جسد المتوفى لافتقادها للطهارة الطقسية، وبالتالي وجب عزلها عن الجسد ووضعها في وعاء التكنو، الذي ينتابه اسمه مع اسم

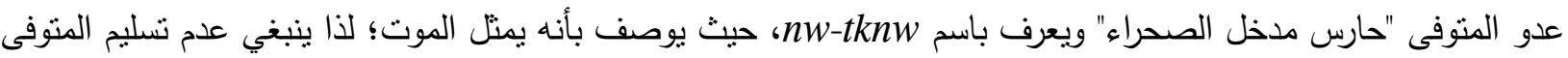

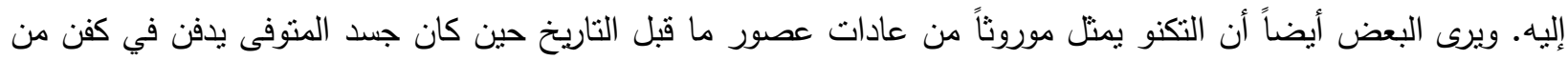
جلود الحيوانات.

TEETER, Religion and Ritual, 138; AssMANN, J., Death and Salvation in Ancient Egypt, USA, 2005, 308, note 21, 22; ZANDEE, J., "Death as an Enemy", inStudies in the History of Religions, Leiden, 1960, 207. 


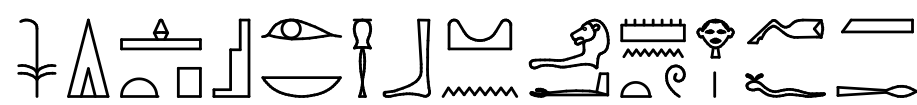

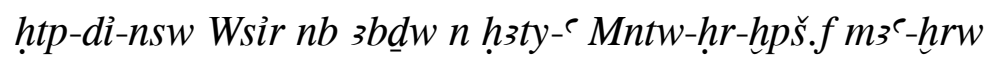

" قربان ملكي (ل) أوزبر سبد أبيدوس، لأجل العمدة مونتو -حر - خبش.إف صادق الصوت". وبالتالي فإن

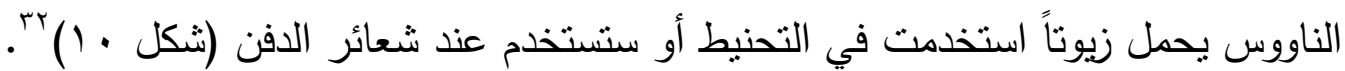
يعلو مشهر التابعين للناووس النص التالي:

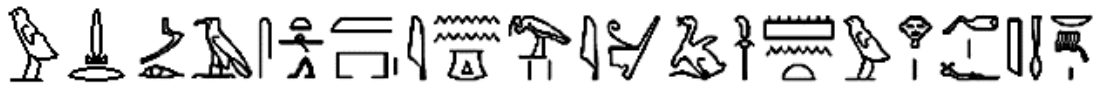

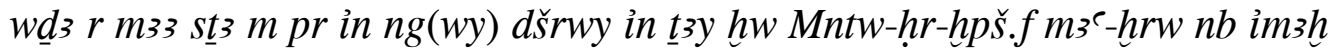

" التقدم لمشـاهدة سحب (التابوت) من المنزل، بواسطة ثورين أحمرين. إن حامل المروحة مونتو - حر -

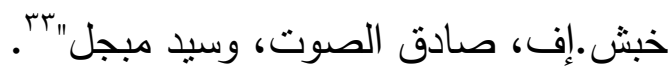

يتقدم موكب التابوت شخصيات مهمة يحملون ألقاب: الكاهن المرثل، وكاهن سم، ثم السمير، ثم المعروف لدى الملكءّ، وأخيراً الكاهن المحنط، ويتجهون نحو سياج يمثل مقصورة بداخلها عمود جد وكبش هوب منديس، وخارج السياج مائدة قربان يعلوها فخذ وقلب وأضلاع ثور (شكل (1))، يرى Tassie أنه يمثل مبنى في الجبانة زاره الكهنة قبل الدفن. ويرى البعض أن كبش منديس وعمود جد رمزا أوزير يرمزان للحماية والثبات وانتصار المتوفى على الموت وبالتالي البعث وتجدد الميلادّْ.

يتبع الثخصيات سابقة الذكر موكب يصور تابوتاً فوق زحافة يسحبها ستة ثيران حمراء، تم تقمم

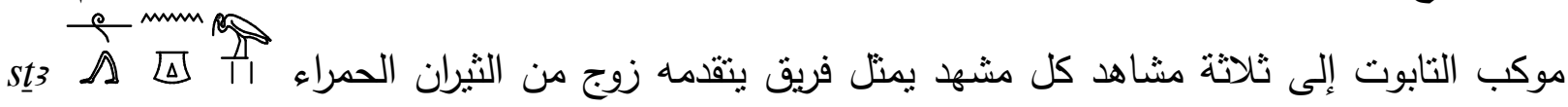

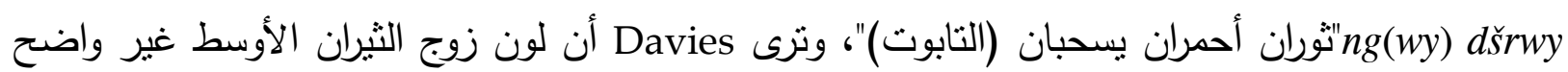
لكن ربما توجد بقايا لكلمة dِ w3

يتكون القريق الأول من ثورين (شكل r I ( ) يساعدهم ثلاثة أشخاص، وخلفهم رجل تعلوه كلمة

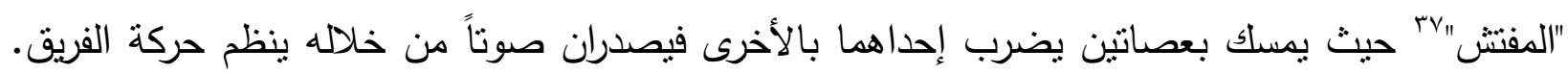

${ }^{32}$ Davies, N. G., Five Theban Tombs, London, 1913, 1, 10, 11, PL.II; TAsSIE, G. J.: «Bulls, Hair and the Teknu», PIA 11, 2000, 28; MASPERO, Montouhikhopshouf, 439; PM. I, 35.

${ }^{33}$ DAVIES, Five Theban Tombs, 10, 11, PL.II; MASPERO, Montouhikhopshouf, 440.

عَّ ظهر لقب rh-nsw " المعروف لدى الملك" منذ الدولة القديمة، ويخص موظف بالبلاط الملكي، مهامه تتعلق بالمشاركة في المر اسم الجنائزية الملكية و الخاصة، ويتبع الإدارة المالية للقالقصر.

GeISEN, C., The Ramesseum Dramatic Papyrus a New Edition, Translation, and Interpretation, Toronto, 2012, 202.

${ }^{35}$ MASPERO, Montouhikhopshouf, 440; TASSIE, Bulls, Hair and the Teknu, 28,29; STEVENS, Le Tekenou et son Implication, 115, 116.

${ }^{36}$ DAVIES, Five Theban Tombs, 11, note 3; STEVENS, Le Tekenou et son Implication, 115.

${ }^{37}$ JONES, An Index of Ancient Egyptian Titles, 910. 


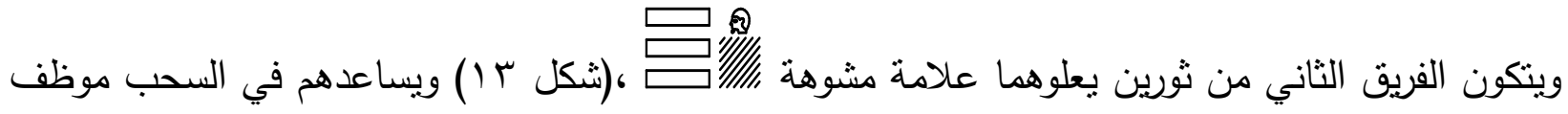
طمس لقبه، وخلفه

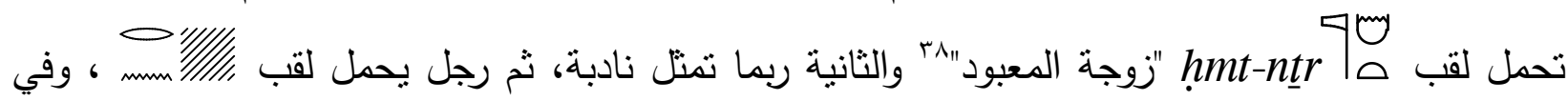

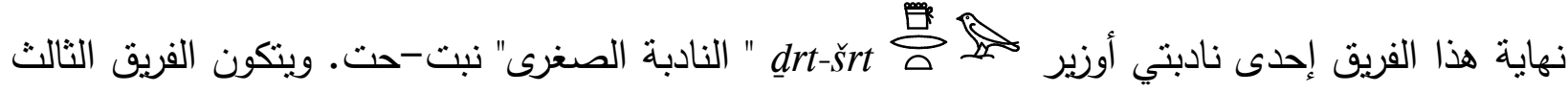

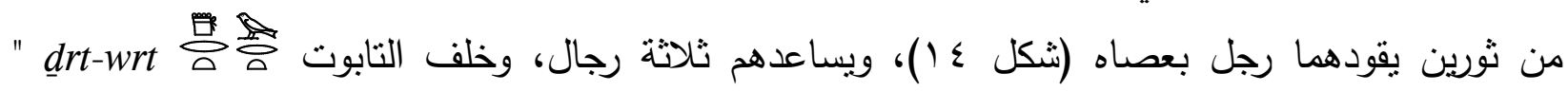

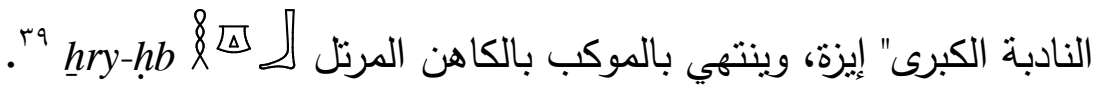

جدير بالذكر أن بعض الكهنة قد تكرر ظهورهم في أكثر من مشهر من مشاهد منظر الجنازة، منل الكاهن المرتل الذي ظهر في نهاية موكب التكنو ثم ظهر مرة أمام ومرة خلف موكب التابوت، كذلك ظهر الموظف الملقب بـ rh-nsw أمام الموكب الجنائزي ثم ظهر وهو يعاون ثيران الفريق الثاني للثيران في سحب التابوت، أيضاً الكاهن المحنط شارك في سحب التكنو وشارك في سحب التابوت خلف فريق الثيران التاني، حيث أراد الفنان التعبير بوضوح عن الحركة السربعة للموكب، رغم وجود كاهن shِd الذي ينظم خطوات فرق السحب والثيران، حيث يتبادل بعض المشيعين الأماكن ويحدث هذا في الجنازات حتى يومنا هذا. يلاحظ في مشاهد الموكب الجنائزي التي وردت عند Maspero أن ماثية سحب الموكب وحتى في

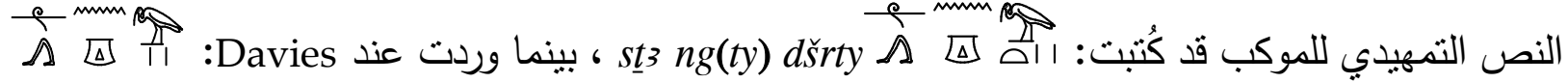
ng(wy) dšrwy • ثيران حمراء؛ $n g(w y)$

جدير بالذكر أن الفريق الثاني للثيران يعلوه ثلاثة أشكال مسنطيلة عِّ، يرى البعض أنها نمنل بحيرات مقدسة أو بحيرات للتطهير ، وقد ظهرت في عدد قليل من المقابر منل مقبرة رخمي -رع رقم . . 1 في جبانة شيخ عبد القرنة، (شكل 0 (1) ومقبرة حقا-ماعت -رع-نخت رقم Y r في جبانة قرنة مرعي من عهد رمسيس الثالث والرابع، إلا أن هذه البحيرات وردت بمقبرة رخمي -رع مصحوبة بأسماء كالتالي: بحيرة خبري،

^ كان لقب "زوجة المعبود" في بداية ظهوره لقباً شرفياً، وكتب قبل الأسرة الثامنة عشرة بشكل مختصر hmt-ntr دون إضافة اسم أي معبود إليه، لكن مع بداية الدولة الحديثة ظهر اللقب بشكله الكامل ntr n Imn، وكان وثيق الصلة بالبيث الحاكم حيث صار حكراً على الزوجة الرئيسة للملك أو ابنة المللك، ومنذ عهد تحتمس الثالث فصاعداً رتبط بالكهنة الأثرياء، كما نالت زوجة المعبود مع بداية الأسرة التاسعة عشرة مكانة سياسية. AYAD, M. F., God's Wife, God's Servant, the God's Wife of Amun (C.740-525 BC), London, 2009, 3-6. ${ }^{39}$ MASPERO, Montouhikhopshouf, 441.

${ }^{40}$ DAVIES, Five Theban Tombs, 10, 11, PL.II; MASPERO, Montouhikhopshouf, 441, FIGS.2,4. 
بحيرة حقات، بحيرة سوكر، وبالتالي عبرت نلك الأشكال عن مناطق تتصل بالتحول والخلق وترتبط بمعبودات، وهكذا عبر الفنان عن مرور الفريق الثاني بمنطقة بحيرات لمعبودات ترتبط بإعادة البعث والتجدد

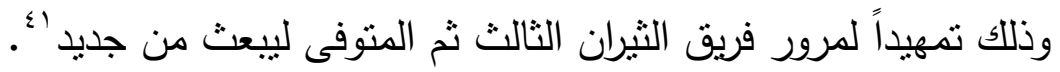

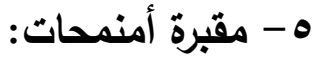

تخص المقبرة رقم r ^ بجبانة شيخ عبد القرنة أمنحات r؛ الكاتب ومحصي الحبوب لأمون، من عهر الملك تحتمس الثالث، يظهر على الجدار الجنوبي للصالة الطولية موكب الجنازة(شكل 7 (1)، حيث ترقد

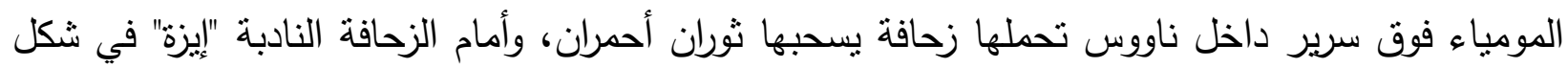
سيدة يعلو رأسها لقب الحدأة الكبرى، وخلف الزحافة النادبة "نبت-حت" في شكل سيدة يعلوها لقب الحدأة الصغرى، ويقود الثورين رجل يرفع سوطه نحوهما، وخلفه رجلان برفعان ذراعيهما للتعبير عن الحزن والرثاء،

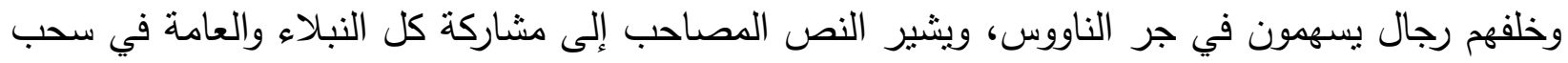

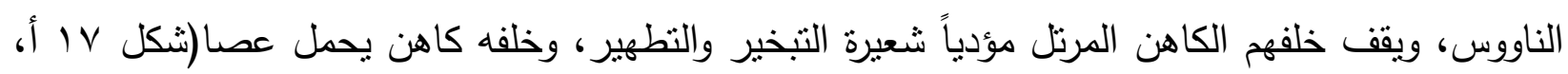
ب، ج، د)، وفي نهاية المشهد خلف الزحافة نص يعبر عن حديث جاء فئرة فيه:

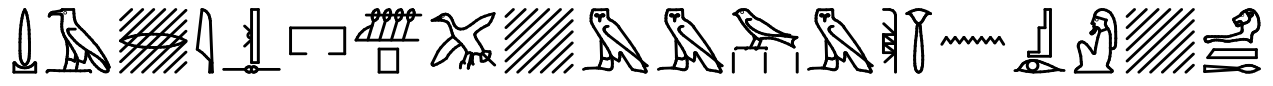

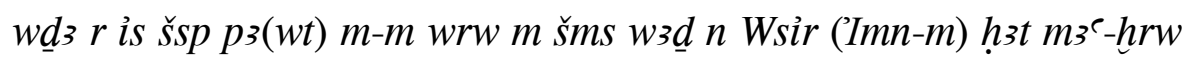

" تقدم نحو المقبرة، وتسلم القرابين بين العظماء، في الموكب الجنائزي لأوزير أمنحات صادق الصوت" ثنانياً: مشاهد مشاركة الأبقار في الموكب الجنائزي: 1 - مقبرة نب-أمون و إبوكي:

المقبرة اN| بجبانة الخوخة تخص كلاً من Ipwky Nb-Imn؛ وقد حمل كلاهما لقب رئيس

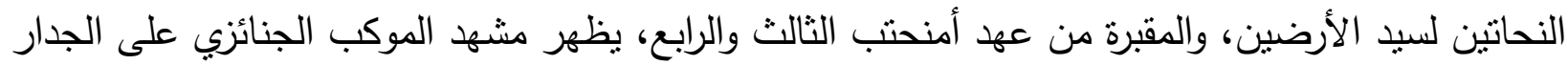

${ }^{41}$ GómeZ, La Procesión Funeraria, 40, FIG.7; DAVIES, N. G., The Tomb of Rekh-mi-Re at Thebes, II, New York, 1943, PL.LXXXVII.

r" تعد مقبرة "أمنحات" واحدة من أكبر وأجمل مقابر جبانة طيبة، حيث كان صاحبها ذو ثروة كبيرة، لكنه لم يثغل أحد

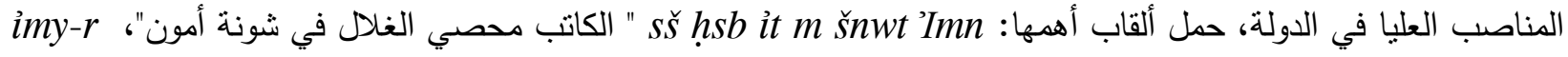
كال هي tsty

نال هذا اللقب بشكل شرفي ولم يمارس الاختصاصات الفعلية للقاضي. DAVIES, N. G., The Tomb of Amenemhet, London, 1915, 1-7, PL.XXXVII; AL-AYEDI, Index of Egyptian Administrative, 74, 579.

${ }^{43}$ PM. I, 163,165; Davies, The Tomb of Amenemhet, 48, 49, note 10, PLS. XI,XII.

؛؛ لا شك أن كل من النحات "تب-أمون" و "إبوكي" قد نالا مكانة في المجتمع بفضل عملهم كنحاتين في البلاط الملكي،

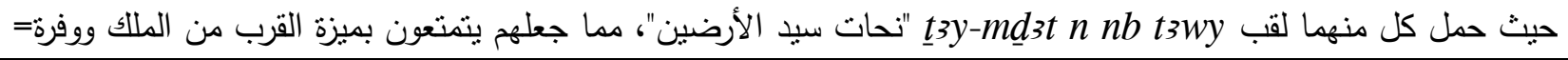


الغربي للصالة المستعرضة في صفين(شكل ^1()، كما يوجد في الصف العلوي بقرات خلفها رجال يساعدون

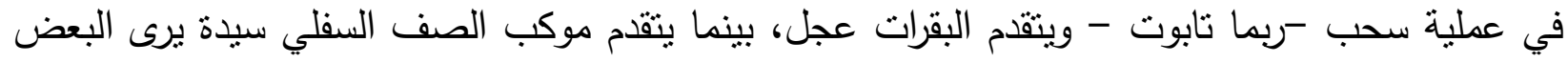
أنها تمسك بمبخرة بدائية بشكل صدفتين ويرى البعض الآخر أنها تمسك بآلة موسيقية، وخلفها بقرتان

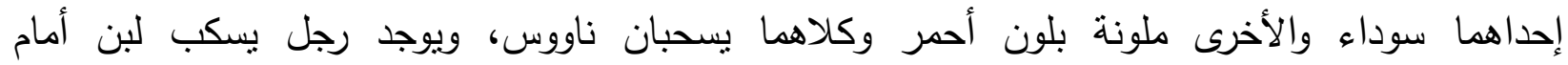

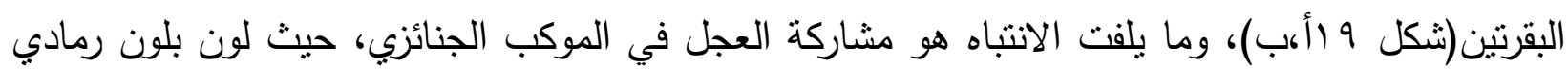

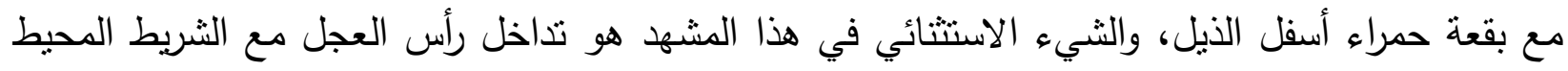

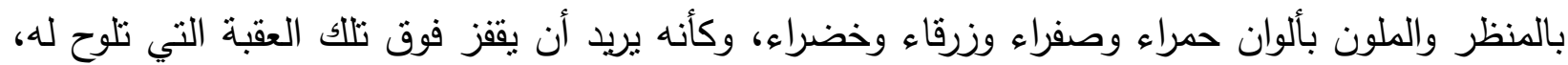

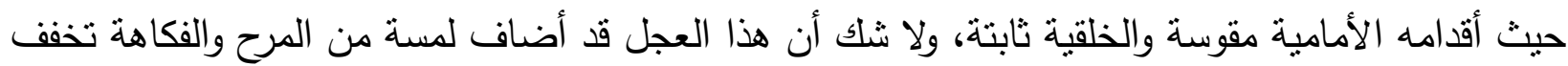

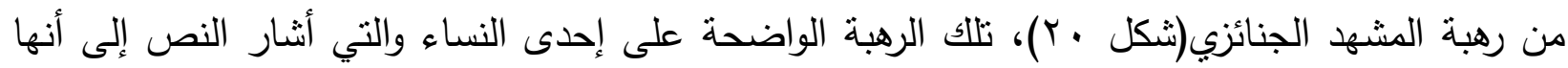

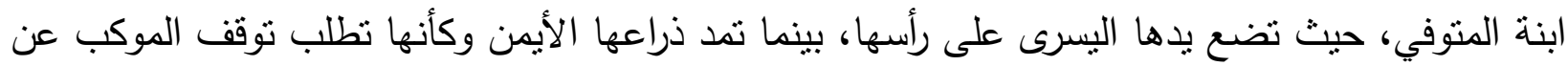

-

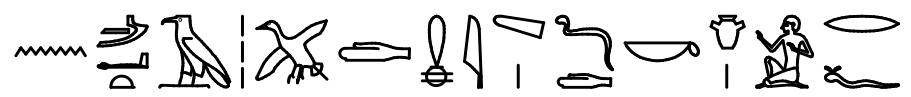

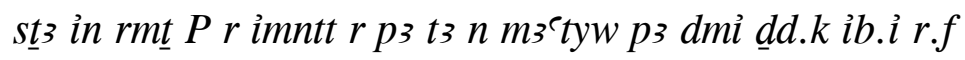

" السحب بواسطة أهل "ب" إلى الغرب، نحو أرض الصالحين، (إلى) المكان الذي قُلت (عنه): إن قلبي

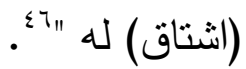

=الهبات والهكافآت. كتب لقب t3a

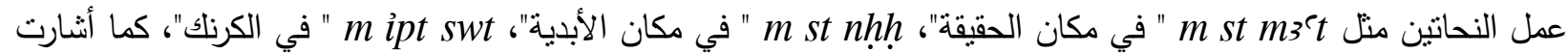

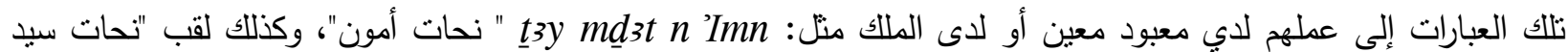

AL-AYEDI, Index of Egyptian Administrative, 644-648.; DAVIES, The Tomb of Two Sculptors at Thebes, 13; Wb. II, $188,10$.

45 PM. I, 286; DAVIES, The Tomb of Two Sculptors, 42, 43, PLS. XXII,XXIII; MEKHITARIAN, A., The Great Centuries of Painting, Egyptian Painting, II, Brussels, 1957, 124, 126; SCHEIL, V.: « Le Tombeau des Graveurs », in Tombeau Thébains, MMAF 5, 1894, 566, PL.VII.

${ }^{46}$ LÜDDECKENS, Untersuchungen über Religiösen Gehalt, 82. 
يتضمن النص أيضاً حديثاً إلى بقرات الموكب الجنائزي:

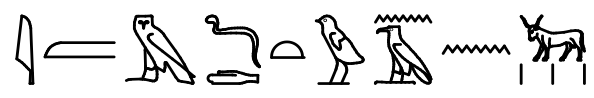

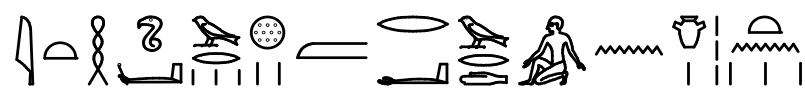

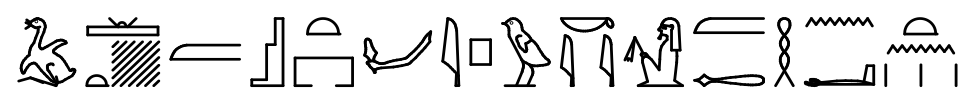

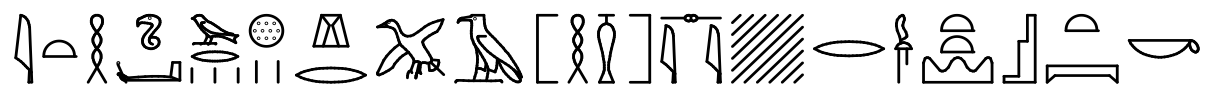

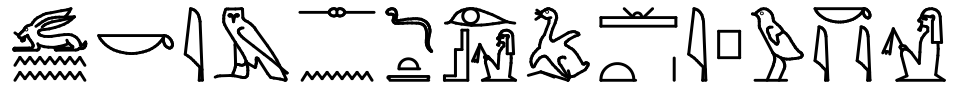

min

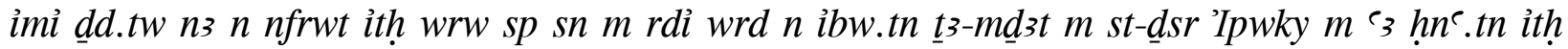
wrw sp sn hry pз hsy ... r imntt st.k wnn.k im.s $n \underline{d} t$ Wsir ț $3-m d \underline{d}$ t' Ipwky wn n.k 3hty imntt

" دع المرء يقول للبقرات، اسحبوا بشدة بشدة، ولا تجعلوا قلوبكم تتعب، إن النحات إبوكي في الجبانة يمجد

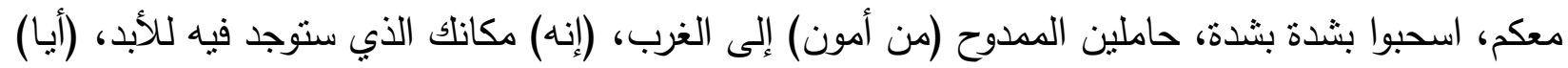

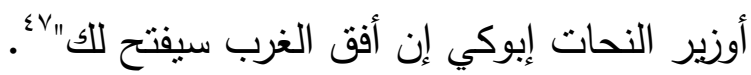

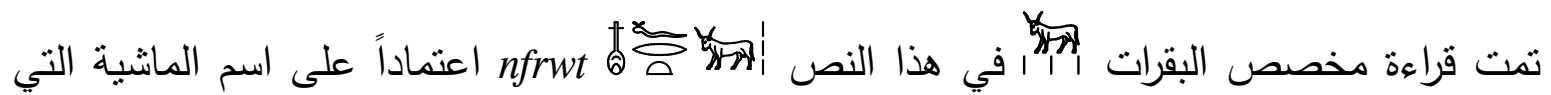
تجر تابوت أمون -مس من عهد تحتمس الرابع إلى أمنحتب الثالث والمصورة بمقبرته رقم 19 بجبانة ذراع أبو النجا، ويمتل nfrwt نوع من الماشية استخدم بشكل عام في السحب والحرث و و عُدَّ نوعاً من ماثشية

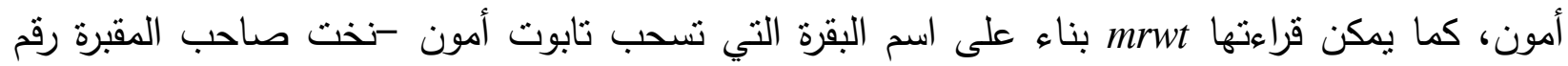

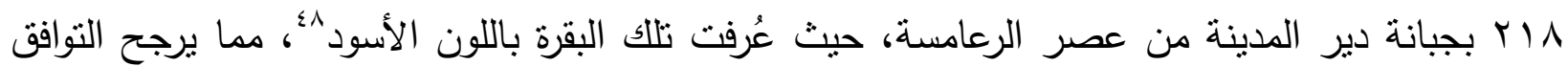

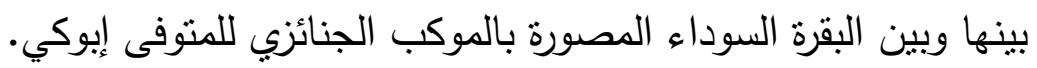

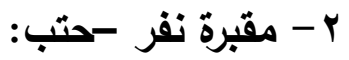

يوجد على الجدار الثرقي للصالة المستعرضة بمقبرة كاتب أمون نفر -حتب رقم 9 ؛ بجبانة الخوخة

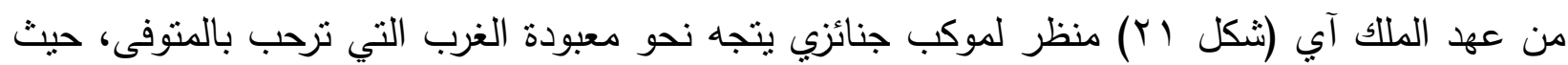

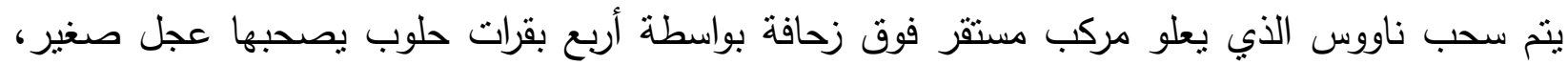


وتتقدم الناووس إيزة وخلف الناووس نبت-حت، يساعد الأبقار ثلاثة رجال، يتقدهم رجل يرفع عصاه، ويتقدم الأبقار رجل ينثر الحليب في طريق الزحافة، ويمكك الكاهن المرتل ببردية يتلو منها شعائر الخدمة الجنائزية (ثكل r r أ، ب)، ويتقدم الموكب رجل يسحب التكنو ، وأمامه رجلان يحملان قرابين إلى المقبرة، وفي مؤخرة

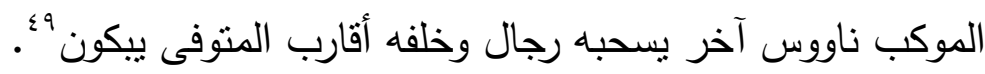

جدير بالذكر أن نفر -حتب نال لقب مميز اختلف عن لقب imy-r sšw " رؤساء الكتبة"، حيث حمل

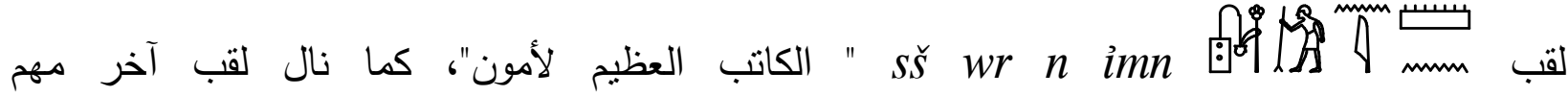

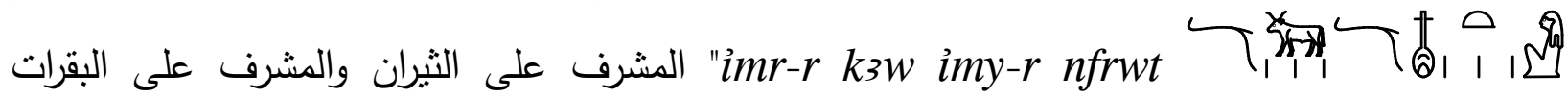

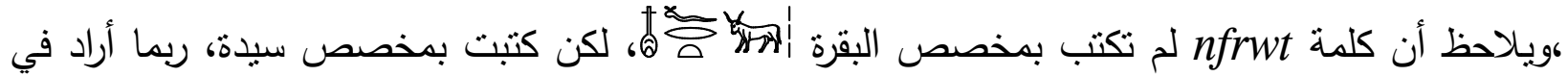
لقبه تمييز الماثية بين الذكور (الثثران) والبقرات(الإناث).يتضح مما سبق أن مكانة نفر -حتب الاجتماعية

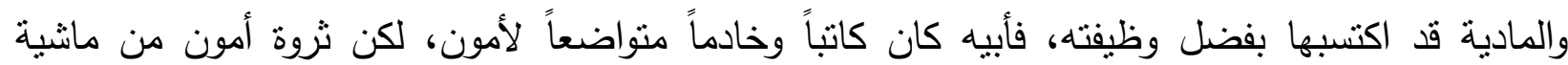

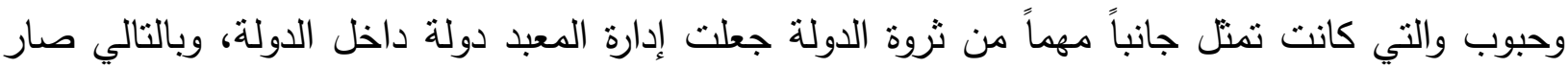
نفر -حتب صاحب مكانة اجتماعية مرموقة وثروة بصفته الكاتب العظيم لأمون والمشرف على ثيران وبقرات

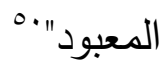

\section{ثالثاً: حديث البقرات المشاركة في الموكب الجنائزي:}

غالباً ما يصاحب مشهد الماشية المشاركة في الموكب الجنائزي نصوص موجهة إلى الماشية، تحثها

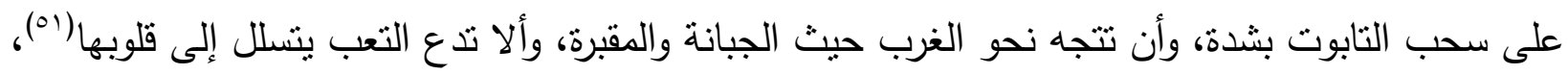

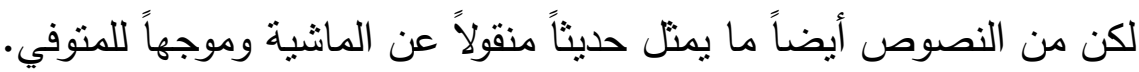

\section{ا- مقبرة وسر Wr}

صور على الجدار الجنوبي لمقبرة وسر بo الكاتب والمشرف على أراضي أمون رقم • بr بجبانة ذراع

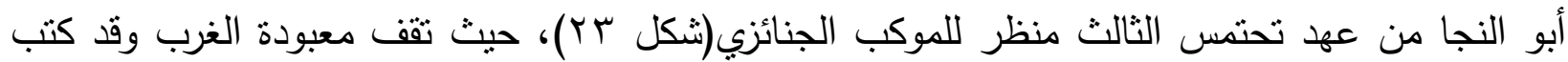

49 PM. I, 91; DAVIES, N. G., The Tomb of Nefer-Hotep at Thebes, I, New York, 1933, 42, PL.XX.

${ }^{50}$ DAVIES, The Tomb of Nefer-Hotep, 17-19, PLS.XXX, XXXIV; AL-AYEDI, Index of Egyptian Administrative, 135.

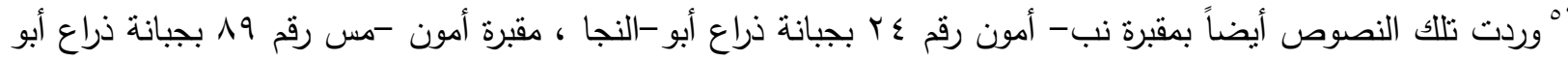

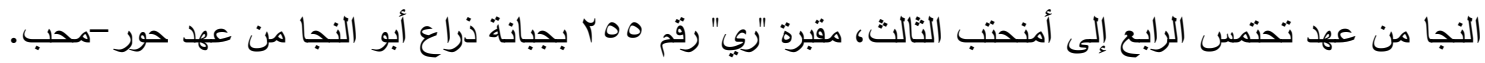
LÜDDECKENS, Untersuchungen über Religiösen Gehalt, 72, 75, 76, 119; PM. I, 41, 181, 339.

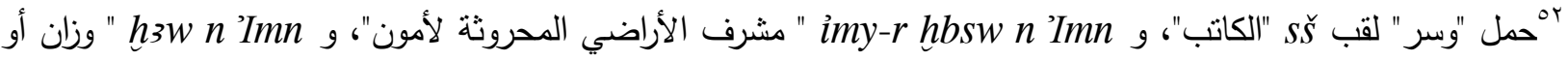

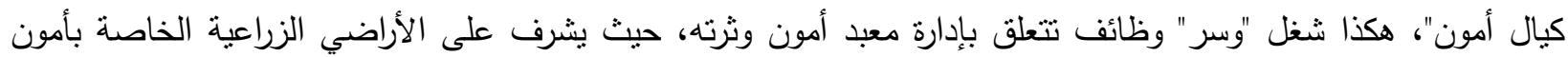

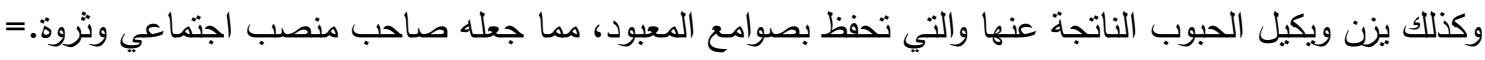


أمامها stz hr imntt " السحب نحو الغرب"، وأمام المعبودة مقبرة يتجه إليها حملة القرابين، خلفهم بقرات يسحبن التابوت،(ثكل \& ب أ، ب) ويعلو الموكب النص التالي:

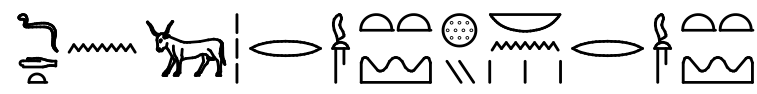

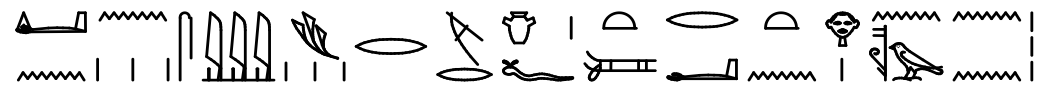

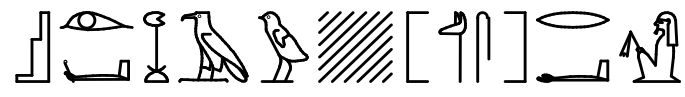

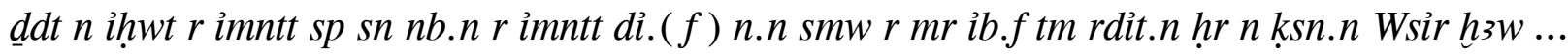
Wsr

" قالت البقرات: إلى الغرب إلى الغرب سيدنا، إلى الغرب، الذي أعطانا العلف وقلبه محب، ولم يتركنا لألمنا،

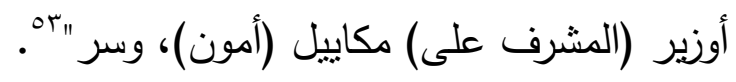

r

يوجد مشهد لموكب جنائزي على الجدار الجنوبي بمقبرة أمون-نخت رقم IX في جبانة دير

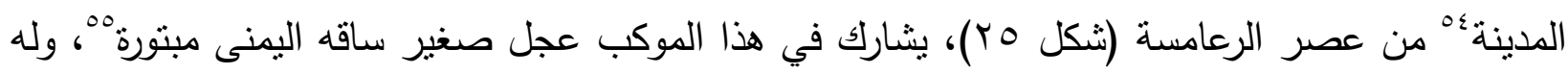

=STRUDWICK, N., The Administration of Egypt in Old Kingdom, London, 1985, 272; NASR, M. W.: «The Theban Tomb 260 of User», SAK 20, 1993, 177; AL-AYEDI, Index of Egyptian Administrative, 124.

${ }^{53}$ NASR, The Theban Tomb 260 of User, 183, 184, PLS.2,3; LÜDDECKENS, Untersuchungen über Religiösen Gehalt, 73, 74 .

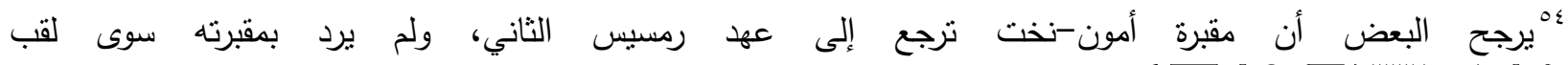

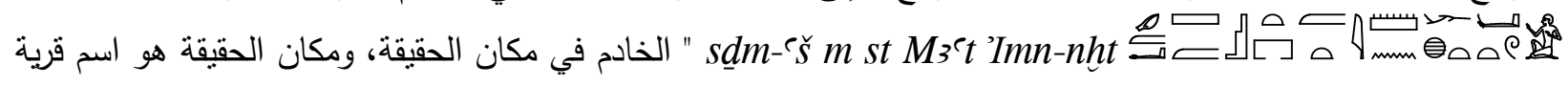
دير المدينة التي تأسست في عهذ تحتمس الأول، لتكون مقراً للعمال والفنانين الذين يعملون في حفر المقابر الملكية، وكان تعيين هؤلاء يتم مباشرة بأمر من الوزير، وهذا يعكس مدى أهمية هؤلاء العمال واهتمام الدولة بهم، إذإن عدم وجود ألقاب تعبر فير فئرئ

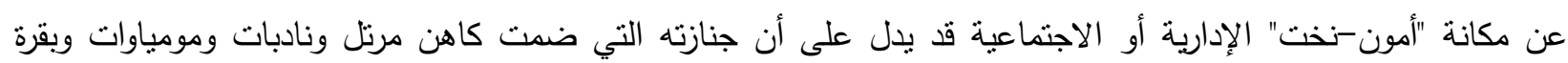
كانت منحة من الدولة تقديراً لمجهود العاملين في مقابر الملوك.

KITCHEN, K. A., Ramesside Inscriptions Historical and Biographical, III, Oxford, 1980, 708-709; LESKO, L.H., Pharaoh's Workers the Villagers of Deir el Medina, London, 1994, 7, 18; DAVIES, B. G., Who's Who at Deir elMedina, Leiden, 1999, 150; BRUYÈRE, B., Rapport sur les Fouilles de Deir el Médineh, V, Le Caire, 1928, 64; AlAYEDI, Index of Egyptian Administrative, 599-601.

0ه ظهر في العديد من مقابر الدولة الحديثة مناظر تمنل عجلاً بصحبة أمه البقرة، ويلاحظ أن العجل مشوه الساق أو مبتور الساق، أو يقوم كاهن ببتز ساقه، والنصوص المصاحبة لمنظر العجل وأمه تثنير إلى البقرة السوداء الباكية، تفسر تلك المناظر حادثة قطع إيزة ليد إينها حور بعد أن لوثها مني ست، وانهو حيث قطعتها إيزة واستبدلتها بأخرى سليمة. GuILHOU, La Mutilation Rituelle de Veau, 277-298; GARDINER, A., The Chester Beatty Papyri №. I, Oxford, $1931,11,4-11,7$. 
جلد مرقط أبيض وأسود، وخلفه البقرة الأم مرقطة أيضاً ولها قرون طويلة، وخلفها رجل لم ييق من صورته سوى الأرجل وعصا وإناء لا شك أنه إناء لبن، أسفل هذا المنظر يظهر الكاهن المرتل حيث تجرى طقسة فتح الفم لاثتين من المومياوات، وخلف الكهنة ست نادبات، تعقد الأخيرتان منهن أيديهن على صدورهن تجسيداً لإيزة ونبت- حت(شكل rr)، ويعلو العجل وأمه النص التالي:
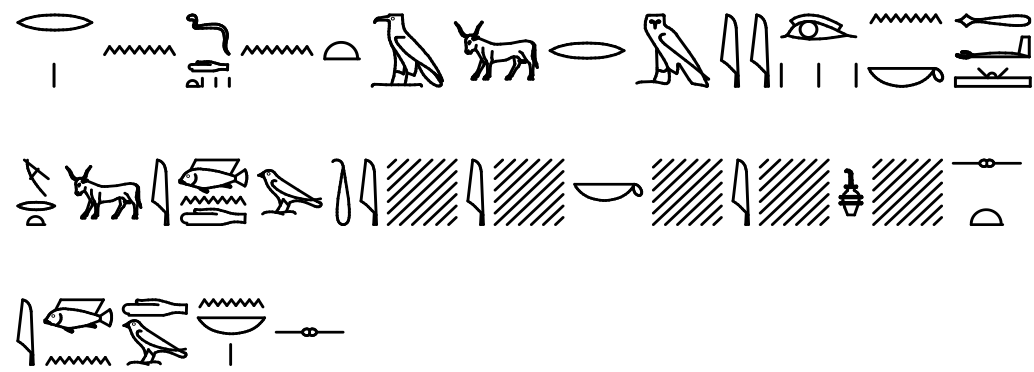

$r n \underline{d} \underline{d} w t$ tz iht $r$ rmy $n . k e_{3}$ mrt ind .ti $(r r) i(s) . k i(w)(i r) t \underline{t}$... ind $n$ nb.s

" حديث البقرة الباكية من أجلك بشدة: البقرة السوداء حزينة، (عند مدخل مقبرتك)، ولبن(ها يراق) حزناً على

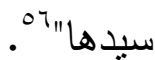

يغلب على حديث البقرات طابع الرثاء والحزن والبكاء، وتعكس تلك الحالة كلمة أه rmyt التي استخدمت منذ الأسرة الثامنة عشرة والتاسعة عشرة للالالة على النادبات له ، حيث وردت rmyt مصاحبة لمنظر النادبات في كل من مقبرة نفر -حتب رقم 9؛ بجبانة الخوخة من عهد الملك آي ^ه، ومقبرة خونس رقم اب بجبانة شيخ عبد القرنة من عهد الملك رمسيس الثاني 9.، مما يرجح أن البقرات الباكيات اللاتي يرثين المتوفى يجسدن النادبتين إيزة ونبت-حت.

\section{رابعاً: ملاحظات على مشاهد الثيران والأبقار في الموكب الجنائزي}

ا - الحالة البذنية لثور الموكب الجنائزي:

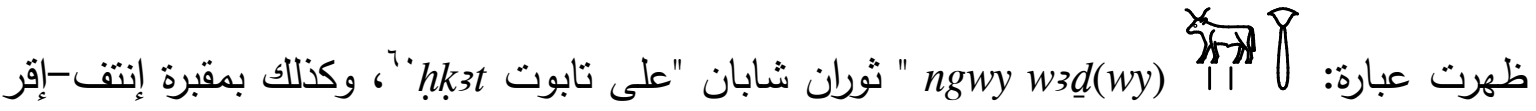

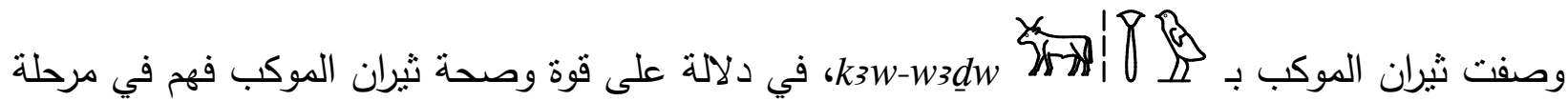

${ }^{56}$ Noblecourt, C. D.: «Concubines du Mort et Mères de Famille au Moyen Empire», BIFAO 53, 1953, $25-$ 27; GuILHOU, La Mutilation Rituelle de Veau, 287, 288, FIG.16; BRUYERE, Rapport sur les Fouilles de Deir el Médineh, 66; LÜDDECKENS, Untersuchungen über Religiösen Gehalt, 154, 155.

${ }^{57}$ GUILHOU, La Mutilation Rituelle de Veau, 294;

نور الدين، الديانة المصرية القديمة، 91 ب.

${ }^{58}$ DAVIES, The Tomb of Nefer-Hotep, PL.XXIII.

${ }^{59}$ DAVIES, N. G., Seven Private Tombs at Kurnah, London, 1948, PL.XVI.

${ }^{60}$ WILLEMS, The Coffin of Heqata, 235, note 1267. 


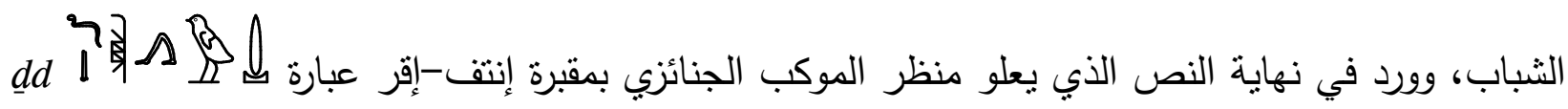
mdw šms wdz " ترتيل الموكب الجنائزي"، وكنلك جاء في نهاية الموكب الجنائزي بمقبرة أمندحات عبارة:

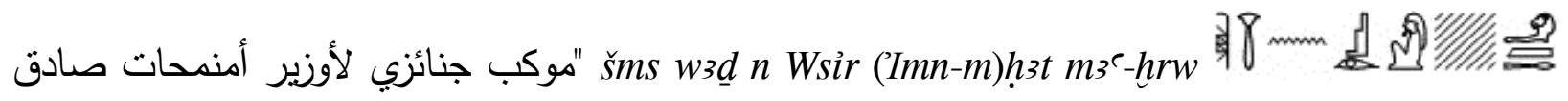
الصوت"، هكذا يرى البعض أن مصطلح يلاحظ أن كلمة لِw3d ارتبطت بثيران الموكب للتعبير عن مرحلة الثباب والقوة، ويلاحظ أيضاً أن كلمة

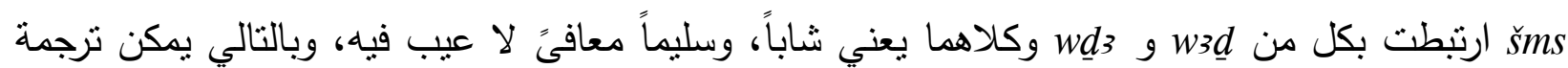

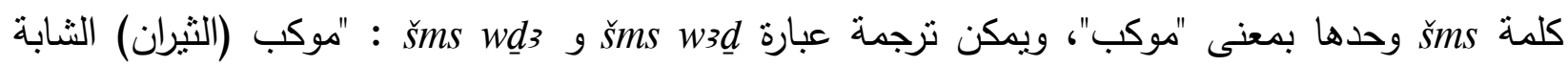

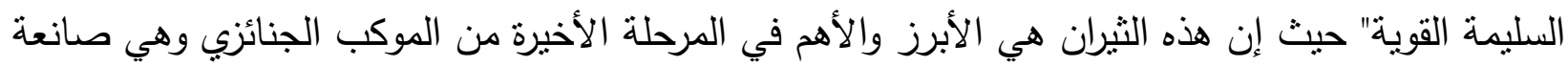

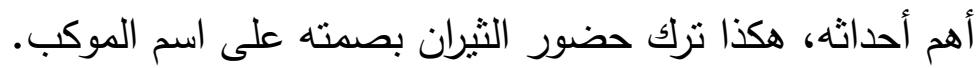

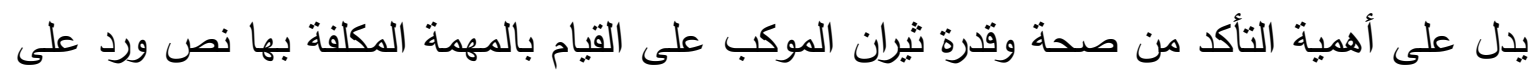

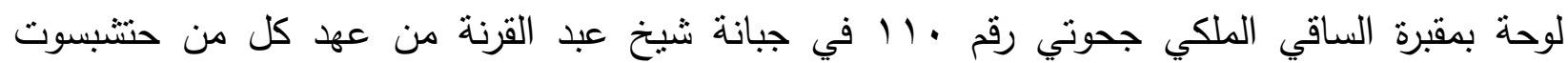

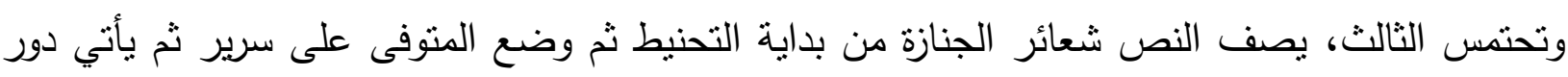

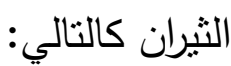

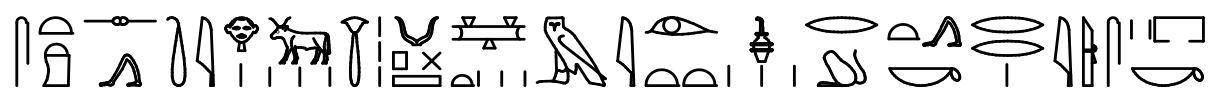

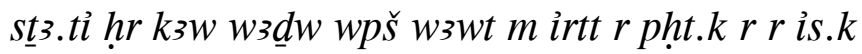

" مسحوباً بثيران سليمة (أي قوية وبلا عيب) والطرق مبللة باللبن حتى وصولك إلى باب قبرك" "ז. يعكس أيضاً الحالة البدنية القوية والمميزة للثيران الحمراء، منظر بمقبرة أمنحات على الجدار الغربي

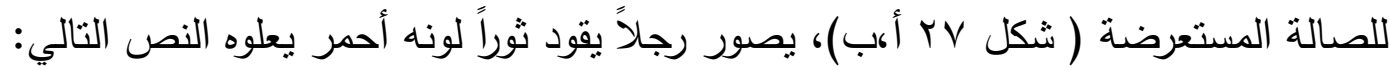

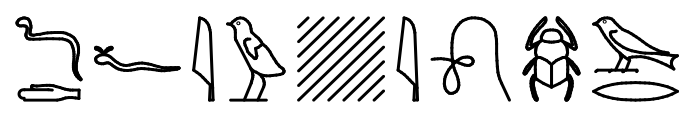

dd.f iws hpr wr

$$
\text { " يقول: الثور صار عظيماً (أي نمى كثيراً) " }
$$

${ }^{61}$ El-Shahawy, The Funerary Art of Ancient Egypt, 37, 97; Davies, The Tomb of Amenemhet, 49, note10, PL.XII.

${ }^{62}$ PM. I, 227; DAVIES, The Tomb of Amenemhet, 56. 
يظهر في نفس المشهد عرالك بين ثورين بصحبهما عبارة:

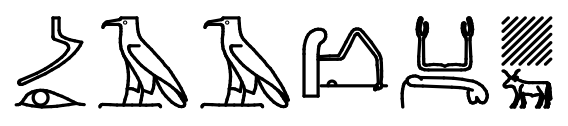

$m 33 \mathrm{Ch}_{3} \mathrm{k} 3(w y)$

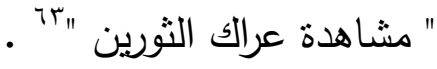

r

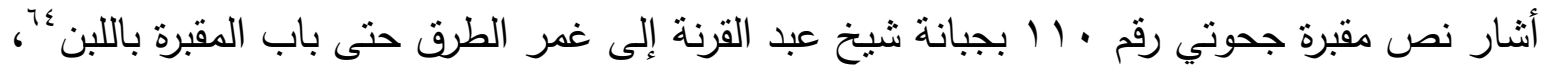
وكذلك يوجد نص آخر نقش على لوحة عثر عليها بمقبرة كاتب المجندين "إنتف" رقم ع 1 إجبانة ذراع أبو النجا يصف المراسم الجنائزية في يوم الدفن ومن بينها دور لبن الماشية:

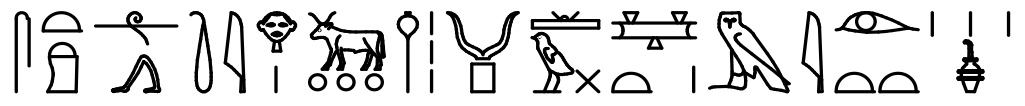

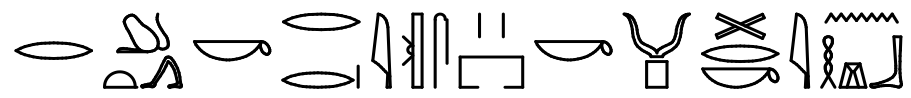

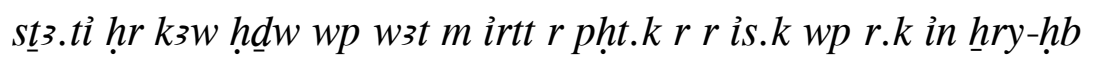

" مسحوباً بثيران مبهجة (طاهرة)، وفتح الطربق باللبن حتى تصل إلى باب مقبرتلك، حيث يفتح الكاهن المرتل

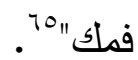

يلاحظ أن هناك اتفاقاً بين نص مقبرة جحوتي ومقبرة إنتف فيما يخص مهمة الثيران بينما يوجد اختلاف في الصفات، فقد تتوعت الصفات بين w3 خضراء بل تعني مضمون الصفة " سليمة وقوية"، فإن عبارة k3w hạ لا تعني ثثراناً بيضاء بل تعني ثثران مبهجة المظهر ونقية طاهرة خالية من العيوب؛ وبذلك تتوافق w3d مع بِ

${ }_{63}$ Davies, The Tomb of Amenemhet, 42, PLS.VI,VIA; WILKINSON, J. G., The Manners and Customs of the Ancient Egyptians, II, New York, 1878, 75; El-Shahawy, A., Recherche sur la Décoration des Tombes Thébaines du Nouvel Empire, London, 2010, 16.

${ }^{64}$ WILSON, Funeral Services, 212.

${ }^{65}$ HermanN, A., Die Stelen der Thebanischen Felsgräber der 18 Dynastie, New York, 1940, PL.4, text 39*.

${ }^{66}$ DAVIES, The Tomb of Amenemhet, 56; FORSHAW, The Role of the Lector (hrry-hbt), 240,259; TEETER, Religion and Ritual, 137; ASSMANN, Death and Salvation, 301. 
يدل على ارتباط هذا اللبن المنثور بماثية الموكب الجنائزي التعويذة رقم"ج ه" من نصوص التوابيت:

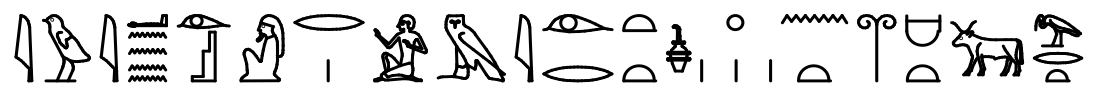

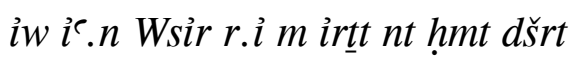

$$
\text { " طهر أوزير فمي بلبن البقرة الحمراء" }
$$

يتضح مما سبق أن نثر اللبن أثناء سير الموكب الجنائزي له أهميته، حيث إن نثر اللبن من الناحية الفعلية يجعل الطريق زلقاً ومن الناحية الرمزية يجعل الطريق إلى المقبرة طاهراًّ، بنفس الطريقة التي لفي يستخدم فيها لتطهير الطريق أمام مواكب المعبودات في الاحتفالات الدينية ب9؛ ونظراً لارتباط اللبن بالمعبودة حتحور والمعبودات الأخرى ذات الصلة بها فإن نثر اللبن يرتبط بتجدد الميلاد، إلى جانب اقتران الطقسة بفتح الطريق المؤدي للمقبرة، وبالتالي يوجد علاقة قوية بين نلك الطقسة وبين طريق المتوفى نحو العالم الآخر، حيث تربط نصوص الموكب الجنائزي بين طريق الجنازة وبين الطريق نحو السماء بما بعني أنه

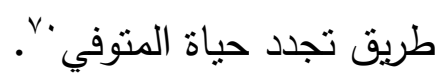
ب- ناثر اللبن:

يظهر بجانب ماشية الموكب الجنائزي ناثر اللبن، ممسكاً بإناء طقسي ظهر في العديد من الطقوس خلال الدولة الوسطى والحديثة، وصنع هذا الإناء من البرونز واستخدم لحفظ اللبن، لكن استخدم أيضاً في العصر المتأخر لحفظ الماء، ويتميز بعنق ضيق وأكتاف بارزة وقاعدة مسطحة لَ، عرف هذا الإناء باسم

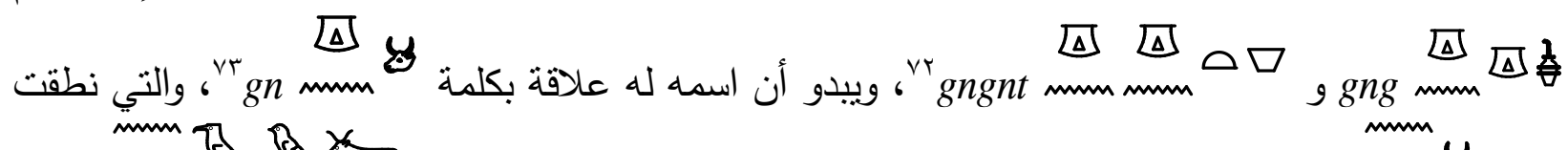

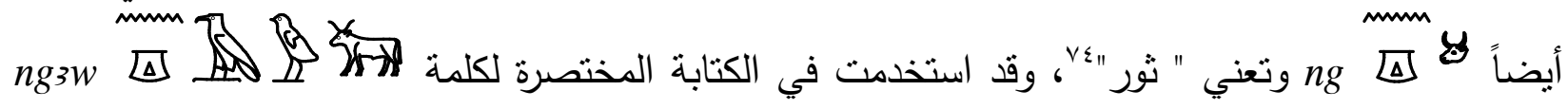
بمعنى "ثيران طويلة القرون"

${ }^{67}$ DE-BUCK, A., The Egyptian Coffin Texts, II, Chicago, 1947, 81, spell 96 b; IVANOvA, M., Milk in Ancient Egyptian Religion, Uppsala, 2009, 22.

${ }_{68}^{6}$ TEETER, Religion and Ritual, 138.

${ }^{69}$ The Epigraphic Survey, The Festival Procession of Opet in the Colonnade Hall, OIP 112, Chicago, 1994, 37.

${ }^{70}$ El-ShahaWy, The Funerary Art of Ancient Egypt, 65; IvanOva, Milk in Ancient Egyptian Religion, 31.

${ }^{71}$ El-Shahawy, The Funerary Art of Ancient Egypt, 66.

${ }^{72} \mathrm{~Wb}$. V, 177, 11.

${ }^{73} \mathrm{~Wb}$. V, 172., 14

${ }^{74} \mathrm{~Wb}$. II, 348, 16.

${ }^{75} \mathrm{~Wb}$. II, 349, 1; HAMmAD, M. B. \& MOHAMED, Y. A.: «Milk Vessels in Ancient Egypt», IAJFTH 3, 2017, 19; The Epigraphic Survey, The Festival Procession, 41,59. 


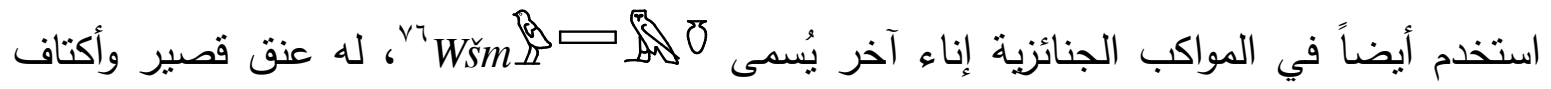

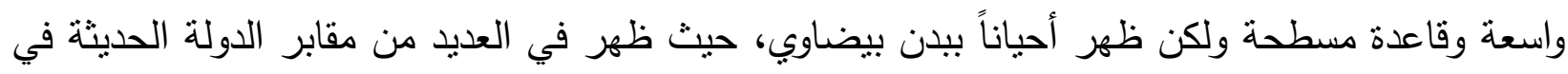

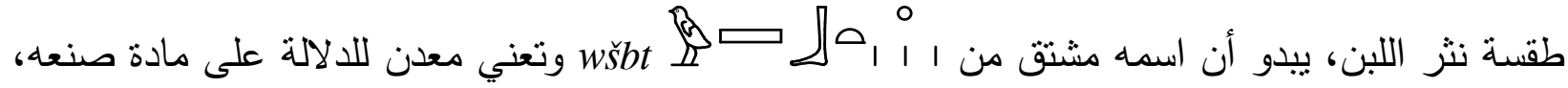

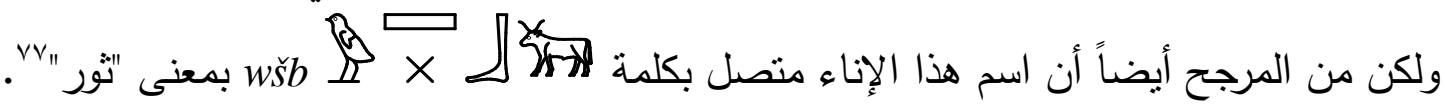
ترى Lichtheim أن نثز اللبن في طريق موكب التابوت يُعد قرباناً يساعد في إنعاش الجسد ويعيد له

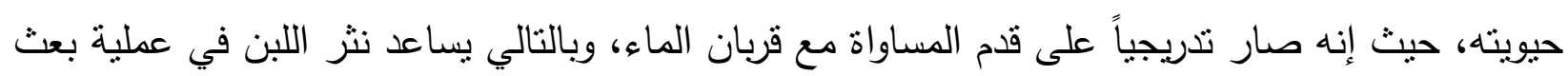

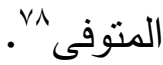

يتضح مما سبق أن نثز اللبن في طريق الموكب الجنائزي يمثل قرباناً بمرور تابوت المتوفى عليه

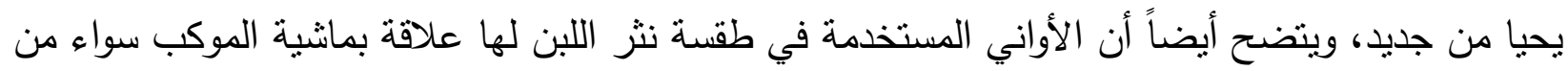

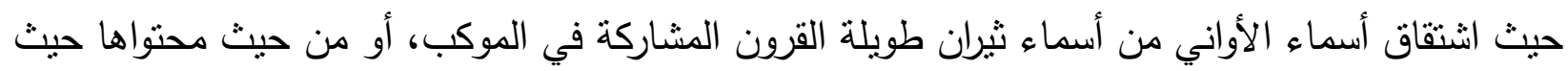

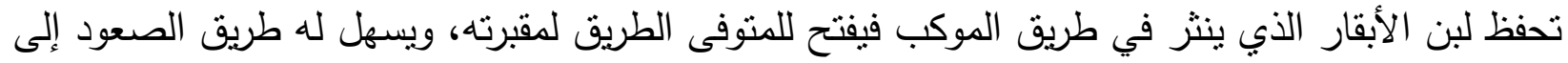
الأفق، بناء على ذلك فإن مانشية الموكب نتارك بمجهودها في سحب الموكب وتُشهم بلبنها في إحباء المتوفى.

يلاحظ أن الظهور المتكرر للماثية في الموكب الجنائزي خلال الدولة الحديثة أثر كثيراً في استبدال

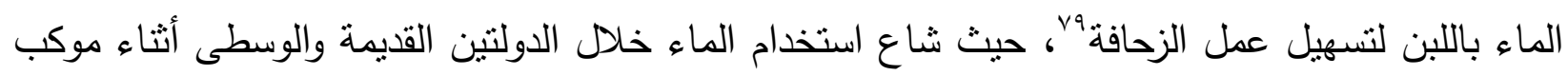
نقل التمثال، ويقوم بطقسة نثر الماء نحو الزحافة موظف يحمل لقب " مدير فريق بيت الأبدية":

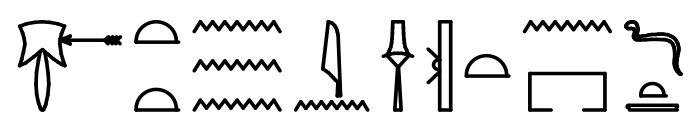

stt mw in hrp ist $n$ pr $\underline{d} t$

" نثر المياه بواسطة مدير فريق بيت الأبدية "•. وبالمقارنة فإن ناثر الماء”ي. يعادل ناثز اللبن وبالتالي يُعد قائداً للفريق، بل الأكثر من ذلك يلاحظ تغير مكان ناثر اللبن من مكان لآخر ، حيث يتحكم في حركة

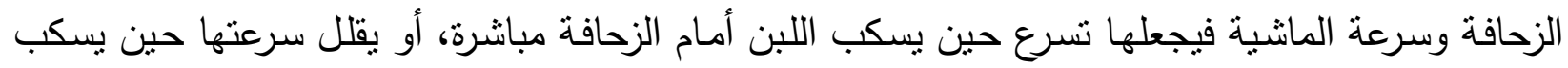

${ }^{76} \mathrm{~Wb} . \mathrm{I}, 374,1$.

77Wb. I, 373, 4; FAUlKNER, A Concise Dictionary, 70; HAMMAD \& MOHAMED, Milk Vessels, 21.

78 LICHTHEIM, M.: «Situla №. 11395 and Some Remarks on Egyptian Situlae », JNES 6, 1947, $172,173$.

${ }_{79}$ Diamond, K, A.: «The Placement of the Sacred District Scene in the Rectangular Tombs at Elkab», JARCE 48, 2012, 100.

${ }^{80}$ EATON-KRAUSS, The Representations of Statuary in Private Tombs, 66, PLS, XV-XVII.

${ }^{81}$ FAULKNER, A Concise Dictionary, 252. 
اللبن أمام الماشية مباشرة أو يحدد لها مكان التوقف حين يسبقها ويقف أمسام المقبرة، يضاف إلى أهمية نثر اللبن تطهير طريق الموكب الجنائزي، والمساعدة في بعث المتوفى وتطهير فمه.

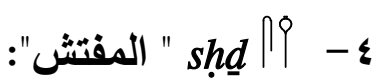

shd يسير خلف الثيران والرجال الذين يسحبون تابوت مونتو -حر خبش.إف كاهن يحمل لقب

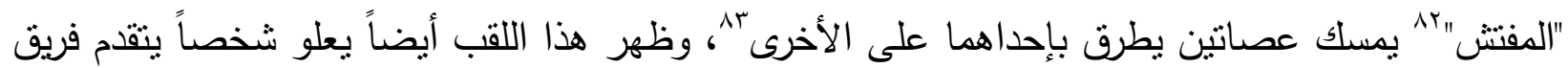
سحب تمثال رع-ثبسس وزير الملك جد-كا-رع بجبانة سقارة، حيث يمسك بطرف حبل الزحافة ويواجه المشاركين في سحب التمثال (شكل ^^)، يبدو أنه يوجه الفريق وينظم حركتهم، كما ظهر هذا اللقب لشخص يدعى رع-ور بالمقبرة رقم 17 بجبانة الجيزة يقود بعصاه ثورين ع^.

كتب هذا اللقب بصيغ مختلفة للتعبير عن وظائف ومهام منعددة، ومن بينها:

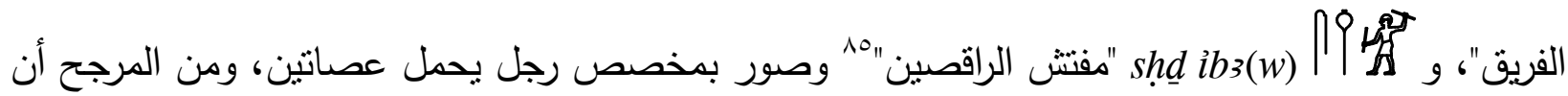
هذا الثخص مسئول عن تتظيم حركة فريق سحب التمثال أو التابوت، حيث ينظم خطوات فريق سحب الموكب الجنائزي وكذلك الماشية؛ وذللك على صوت العصي التي بحوزته. ه - مشاركة الثيران والأبقار في الشعائر الختامية للموكب الجنائزي: أ- الثور الأحمر (المعبود ست): لا تتتهي مهمة الثور بوصول الموكب لباب المقبرة، بل تبدأ مرحلة جديدة غاية في الأهمية، فيها يؤدي الثور دوراً محوريًّا في إحياء المتوفى من خلال شعيرة الذبح والتضحية. فاللون الأحمر للثتر عبر عن مصبره فعقب مشاركته وتحمله العبء الأكبر في نقل مومياء المتوفى تتم التضحية بهـ" آ. ترجم البعض عبارة الثور الأحمر K3-ďrrw بالثثر الدموي في دلالة واضحة تعكس ارتباطه بالمعبود

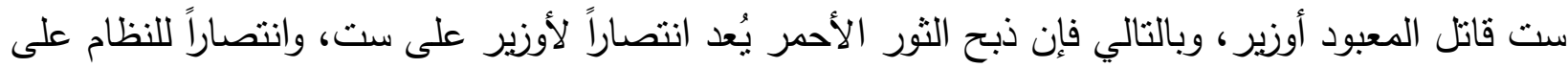
الفوضى واحتواء لشر المعبود ست الذي ارتبط بالصحراء حيث الموت والأعداءءئ.

${ }^{82}$ JONES, An Index of Ancient Egyptian Titles, 910.

${ }^{83}$ MASPERO, Montouhikhopshouf, 441.

${ }^{84}$ Eaton-krauss, The Representations of Statuary in Private Tombs, 151, 66 ,67 note 329, PL.XII; LD, II, PL.54.

85 JONES, An Index of Ancient Egyptian Titles, 910.

${ }^{86}$ WILSON, Funeral Services, 211, note. 51; DIAMOND, The Placement of the Sacred District, 100.

${ }^{87}$ DAVIES, Five Theban Tombs, 11; STEVENS, Le Tekenou et son Implication, 116, 154; Te VeLDE, H., Seth God of confusion, Leiden, 1967, 62, 66, 164; TASSIE, Bulls, Hair and the Teknu, 36; SOUKIASSIAN, G.: «Une Version des Veillées Horaires d'Osiris», BIFAO 82, 1982, 347 note 3. 
لم تكن مهمة ذبح الثور مهمة سهلة حيث يتضح ذلك من خلال منظر بمقبرة سنبي رقم ب في جبانة

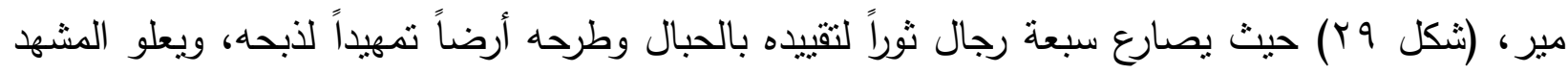

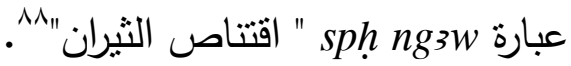

ظهر بمقبرة مونتو -حر -خش.إف على الجدار الجنوبي - نفس جدار الموكب الجنائزي - منظر يمثل الكاهن المرتل ينسلم إناء تطهير من كاهن يقف أمامه، ثم رجل يمسك بقرون ثور يجهزه للابح ،وخلف

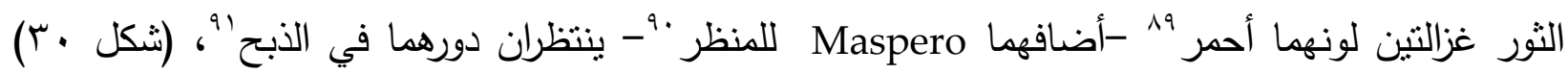

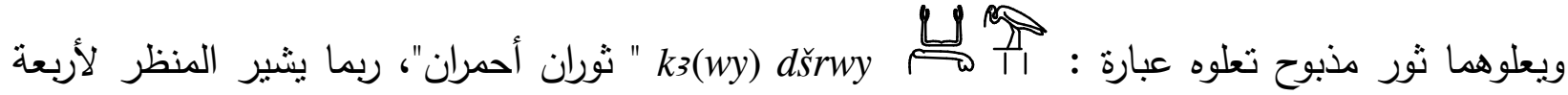

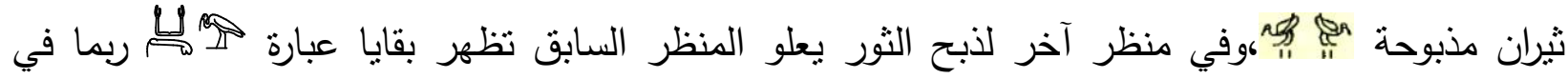

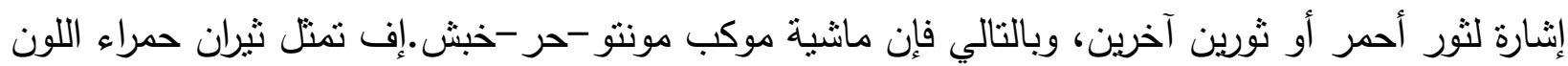

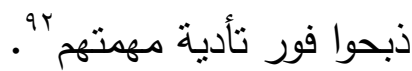

يلاحظ بمقبرة أمنمحات على الجدار الجنوبي أعلى مشهذ سحب مومياء المتوفي منظراً يمنل رحلة

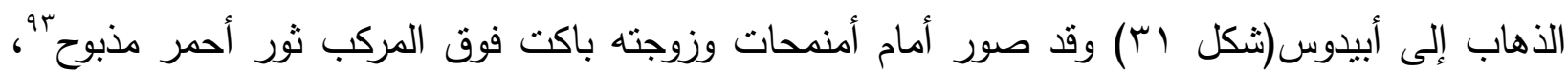

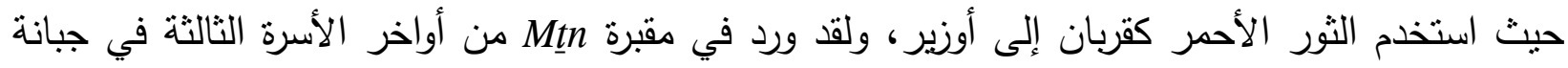

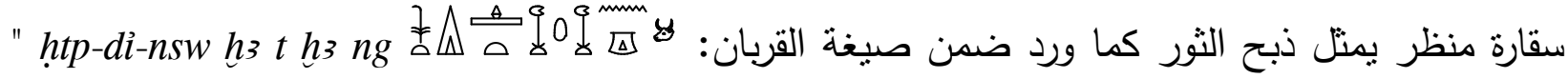
قربان ملكي ألف من الخبز وألف من ثيران ng ".وبالتالي من المرجح أن ثيران موكب أمنمحات كانت أيضاً

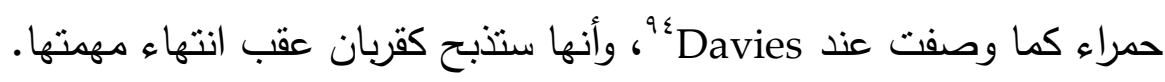
يدل بوضوح على ارتباط بعث أوزير بذبح الثور الأحمر منظر مقبرة مونتو - حر - خبش.إف الذي

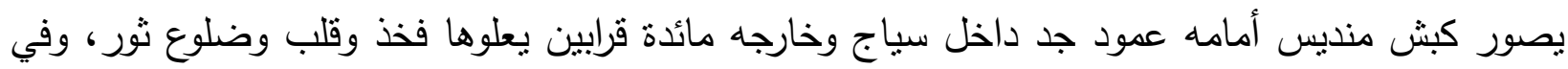

88BLACKMAN, A. M., The Rock Tombs of Meir, II, London, 1915, 13, PLS. III,IV.

9^^ارتبطت الغزالة بأحد أثكال المعبود ست مثلها مثل الثور الأحمر، وقد وصفت الغزالة بأنها سارقة العين المقدة، وبالتالي فإن ذبحها وتقديمها كقربان يعني استعادة حور لعينه التي أطاح بها ست. JUNKER, H.: «Die Schlacht und Brandopfer im Tempelkult der Spätzeit», ZÄS 48, 1911, 72-75.

${ }^{90}$ DAVIES, Five Theban Tombs, PL.X.

${ }^{91}$ MASPERO, Montouhikhopshouf, 461.

92 WILSON, Funeral Services, 203, 205, 211.

${ }^{93}$ DAVIES, The Tomb of Amenemhet, 47, PL.XII.

${ }^{94}$ LD, II, PL.4; DAVIES, The Tomb of Amenemhet, 49, 84; BAUD, M. \& FAROUT, D.: «Trois Biographies d'Ancien Empire», BIFAO 101, 2001, 43; WILKINSON, T. A. H., Early Dynastic Egypt, London, 1999, 123.

صورت أيضاً أنواع الماشية التي تقدم كقربان ضمن مناظر مقبرة Sšst-htp في جبانة الجيزة من بداية الأسرة الرابعة. JUNKER, H., Grabungen auf dem Friedhof des Alten Reiches bei den Pyramiden von Giza, II, Leipzig, 1934, 187, ABB.33; LD, II, PL.25. 
المقابل تظهر الثيران الحمراء نسح مومياء المتوفى، حيث ارتبط أوزير بالمعبود(با-نب-جدت) فصار Wsir b3 nb Dddt

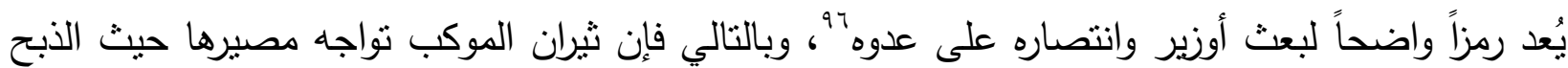
وتقديمها كقربان به يحيا أوزير من جديد.

تستخدم كثيراً الساق الأمامية للثور الأحمر كأداة لفتح فم أوزير وذلك لأن الدم الساخن المتدفق منها

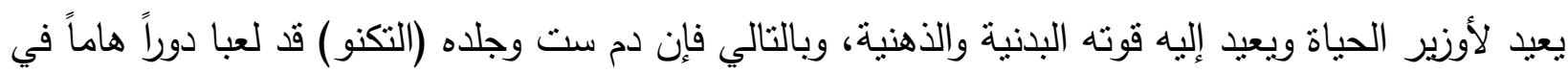
ميلاد وبعث أوزير، وتلك العناصر تأخذ من حيوانات يتجسد فيها ست مثل الثور الأحمر والوعل وكذلك

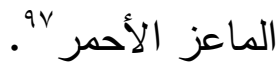

\section{ب- البقرة الحمراء والسوداء (إيزة و نبت-حت):}

كان للثور ng إناث استخدما في الحلب، كما كان للثور iw3 إناث وإن لم تمنل كثيراً، واستخدم كل

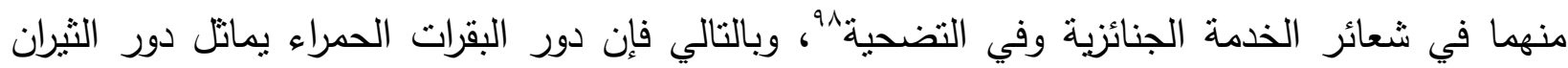
الحمراء في الموكب الجنائزي من حيث مشاركتها في سحب المومياء إلى باب المقبرة، وفي فتح الطريق للموكب من خلال نثر لبنها، وكذلك من خلال ذبحها وتقديمها قرباناً. ورد في التعويذة "Nץ"من منون التوابيت تقديم الثيران الحمراء ذات القرون الطويلة والبقرات الحمراء قرباناً لأوزير :

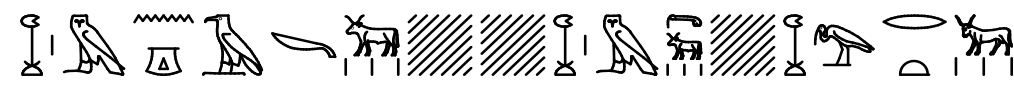

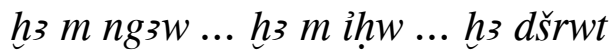

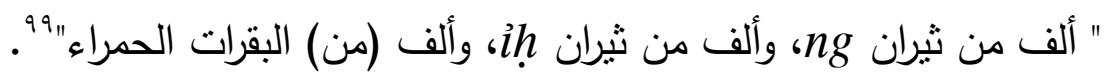

${ }^{95}$ HART, G., Dictionary of Egyptian Gods and Goddesses, London, 2005, 44.

${ }_{96}^{6}$ TE VELDE, Seth God, 32.

${ }_{97}$ Guilhou, La Mutilation Rituelle de Veau, 278, 291; DAVIES, The Tomb of Rekh-mi-Re at Thebes, PL.CV; GoYON, J. C., Rituels Funéraires de l'Ancienne Égypte, Paris, 1972, 126, 45, 46 note.3. ; STEVENS, Le Tekenou et son Implication, 154;

نور الدين، الديانة الدصرية القدبية، HVA ${ }_{98}$ SMITH, In The Domestication and Exploitation of Plants and Animals, 308.

${ }_{99}$ DE-BUCK, Coffin Texts, III, Chicago, 1947, 281, spell 228 e; FAULKNER, R. O., The Ancient Egyptian Coffin Texts, I, England, 1973, 181. 
تثير التعويذة "بو ؟"من متون التوابيت إلى إحضار بقرتين حمراوين عقب وصول المتوفى إلى الثـاطئ

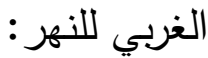

政

ihty. $k$ dšrty

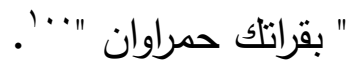

كما ذكرت تلك الأبقار أحياناً بصفاتها الحمراء فقط:

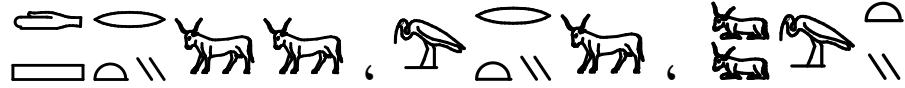

dšrty "الحمراوان"، يرى البعض أن البقرتين الحمراوان يمثلان إيزة ونب -حت اللتين تتتحبان من أجل

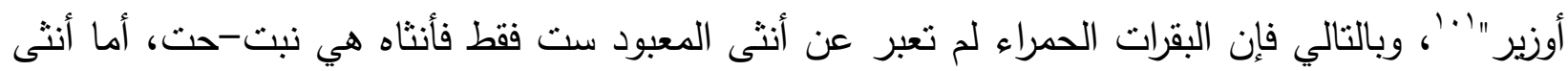

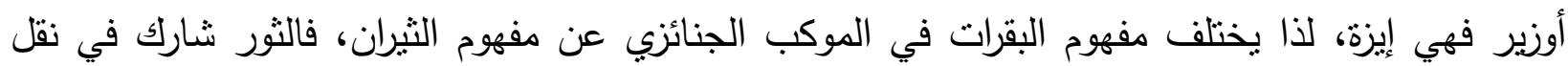

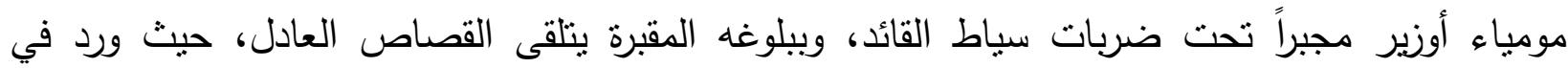

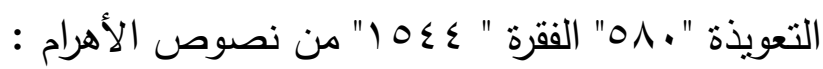

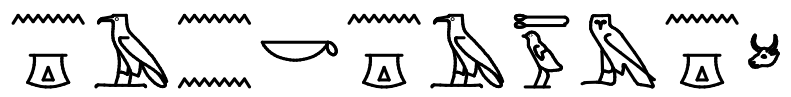

ng3.n.(i) $n . k n g$ t tw $m n g$

" لقد ذبحت لأجلك الذي ذبحك مثل الثور ng". ويتضح هنا أصل الاثتقاق اللغوي لاسم الثور ng حيث

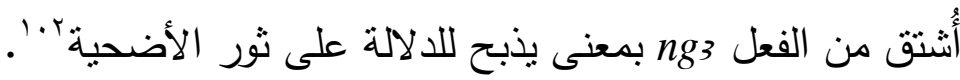

أما البقرتان dšrty فيعبران عن حماية أوزير، ويعبران عن النائحتن إيزة ونبت -حت حيث يتقدمان

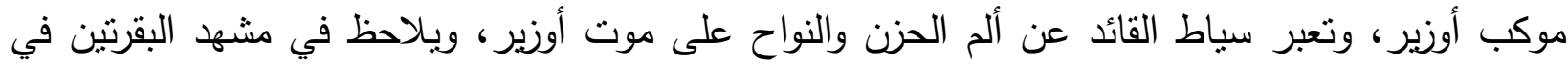

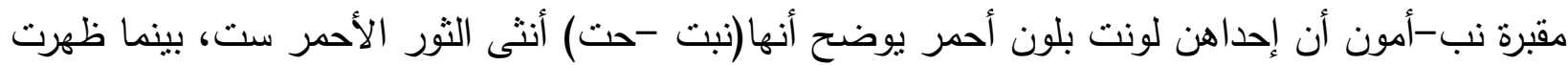

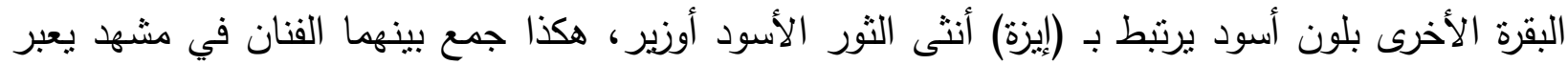

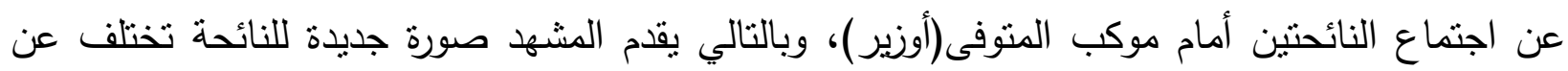

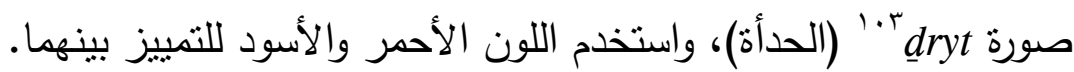

${ }^{100}$ DE-BUCK, Coffin Texts, IV, Chicago ,1951, 45, spell 293 i; FAULKNER, Egyptian Coffin Texts, 218.

${ }^{101}$ LEITZ, Lexikon der Ägyptischen Götter und Götterbezeichnungen, 574.

102 TE VeLDE, Seth God, 97; Otto, E.: «An Ancient Egyptian Hunting Ritual», JNES IX, 1950, 169, 172; Pyr. $1544 \mathrm{c}$.

${ }^{103}$ MORET, A.: «La Légende d'Osiris à l'Époque Thébaine d'après l'Hymne à Osiris du Louvre», BIFAO 30, 1930, 742 note 58. 
يرى Guilhou من خلال دراسته للنص المصاحب لمشهد البقرة السوداء وعجلها المشاركين في الموكب الجنائزي بمقبرة أمون-نخت أن حديث البقرة له طابع الرثاء والحزن والبكاء، وبالتالي يرجح أن البقرة

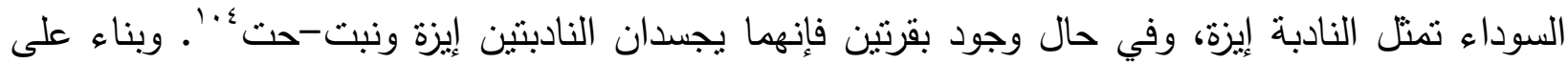
ذللك فإن البقرات المشاركة في الموكب سواء كانت حمراء أو سوداء تمثل إيزة ونبت- حت.

\section{צ- رمزية اللون الأحمر والأسود لماشية الموكب الجنائزي:}

كان للون الأحمر معنى مزدوج في مصر القديمة، حيث حمل معنى سلبيًا وآخر إيجابيًا، فقد عبر عن

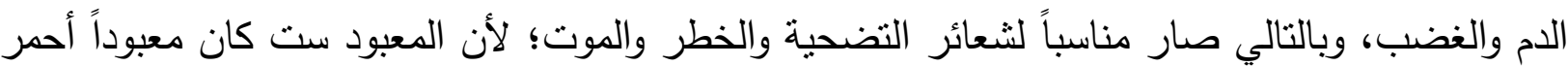
له شعر وعيون حمراء، لكن رغم ذلك حمل اللون الأحمر معنى الحياة فارتبط بالدم كمادة أساسية للحياة ومتعلقة بالميلاد، وارتبط بشروق الثمس كما ارتبط بغروبها، والأحمر لون النار المفيدة والمدمرة في نفس بلس بلاه الوقت، وبالتالي رمز اللون الأحمر للبعث والخصوبة متل اللون الأسود الذي يحمل معنى التجدد والخصوبة الذابة

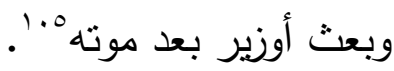

يتضح مما سبق أن الثور الأحمر رمز للمعبود ست المعبر عن الموت والخطر والغضب لاقترابه من المقبرة حيث حان وقت بعث قتيله أوزير وهو أمر يرفضه ويكرهه، ورمزت البقرات الحمراء لحماية أوزير وإعادة مبلاده وتجدد خصوبته وانتصاره على الثر والقصاص من قاتلك. كما أن الجمع بين اللونين الأحمر

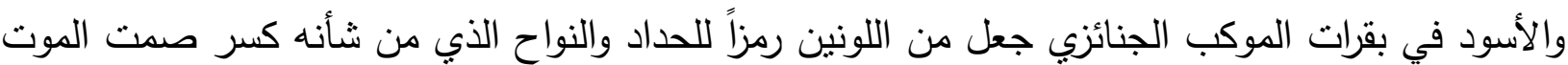
وتجدد حياة أوزير وخصوبته في العالم الآخر .

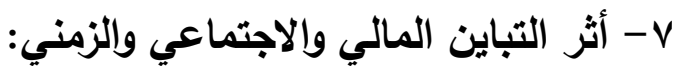
لا شك أن هناك تبايناً كبيراً في مستوى وتفاصيل الجنازات، نتج هذا التباين عن التطور الزمني ومستوى الوضع المالي والاجتماعي لأصحاب تلك الجنازات، يتضح ذاللك التباين من خلادل مستوى المشاركة

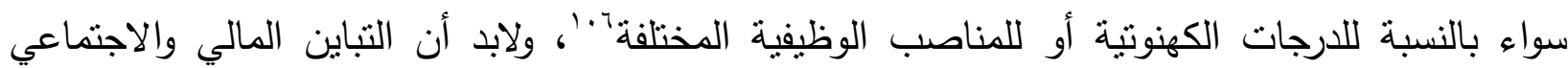
والزمني قد ألقى ببعض ظلاله على الثبران والبقرات المشاركة في سحب الموكب الجنائزي.

${ }^{104}$ GUILHOU, La Mutilation Rituelle de Veau, 294.

${ }^{105}$ PINCH, G.: "Red Things the Symbolism of Colour in Magic", In Color and Painting in Ancient Egypt, 182-185, London: 2001, 183, 184; OWUSU, H., Egyptian Symbols, London, 2000, 48; WILKINSON, R. H., Symbol and Magic in Egyptian Art, London, 1994, 106, 107; ROBINS, G.: "Color Symbolism», In The Oxford Encyclopedia of Ancient Egypt, I, 291-294, Oxford, 2001, 292.

${ }^{106}$ TEETER, Religion and Ritual, 137, 138. 
يتضح من خلال دراسة أهم الألقاب التي نالها أصحاب تلك المقابر أن مشاركة الثيران في سحب الموكب الجنائزي ارتبط غالباً بذوي المناصب الإدارية العليا، فكان منهم الوزير والقاضي، وحامل المروحة

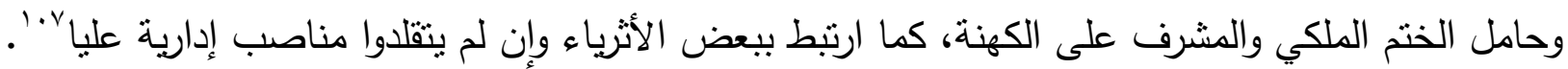
ولا شكك أن المستوى المالي والاجتماعي قد ظهر أنثه على عدد ثيران الموكب، حيث شارك ثوران في

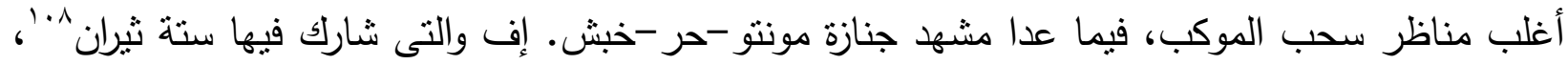

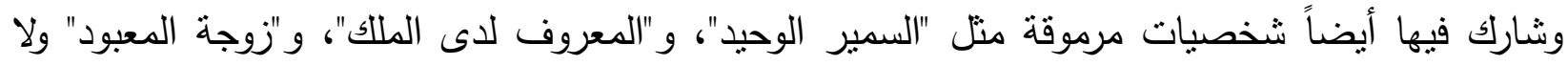
غرابة في هذا حيث تعكس ألقابه الدينية والإدارية وضعه المالي والاجتماعي، فقد شغل وظيفة حامل

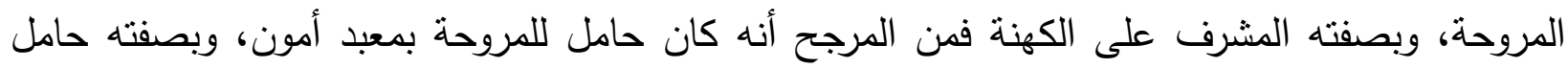

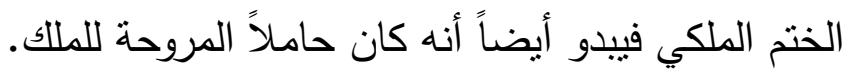

تعطي مشاهد الثيران المشاركة في سحب الموكب انطباعاً عن موكب جنائزي ذو طابع رسمي،

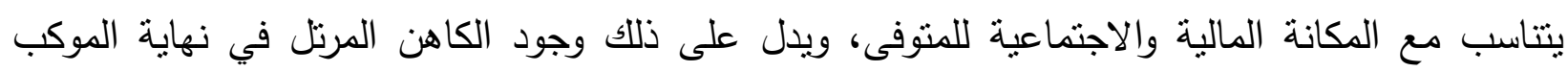
والذى يُعطي الإثارة لبدء التحرك، كذلك ظهر الكاهن shl والذى ينظم خطوات فريق السحب والثنيران

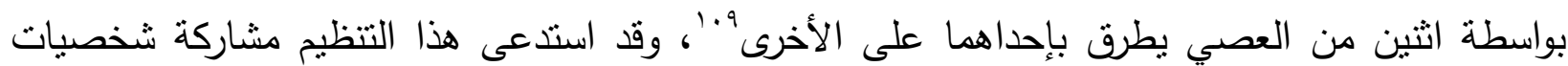
مرموقة من البلاط الملكي في الجنازة.

ل•· لم يكن "حقات" صاحب منصب إداري ولا كهنوتي لكنه كان صاحب ثروة كفلت له مكانة اجتماعية مرموقة، كذلك لم يكن "با-حري" من رجال البلاط الملكي ولا القضاء، لكن كان ذو ثروة كونها من عمله الخاص، كما أنه ينتسب لعائلة ثرية مما وفر لهر له وجاهة اجتماعية جعلت الملك يكلفه بمنصب العمدة، ورغم أن "أمنحات" حمل لقب القاضي وراثة عن أبيه إلا أنه لم لم يمارس القضاء، وإنما بلغ مكانة اجنماعية مميزة بفضل ثرائه. Serrano, A \& Morales, A. J., Middle Kingdom Palace Culture, 223; TYLOR, J. \& GrifFith, F., The Tomb of Paheri, 5-6; DAviES, The Tomb of Amenemhet, 1, 7.

108 DAVIES, Five Theban Tombs, PL. II; MASPERO, Montouhikhopshouf, 441, FIG. 4.

9. ظهر الكاهن المرتل بجوار التابوت وخلف فريق السحب بمشه جنازة "إنتف إقر" يعطي إثارة البدء ليتحرك الموكب، ومن المرجح أن الثخص الموجود خلف فريق سحب التابوت بمشهد جنازة "حقات" يمتل نفس الكاهن يؤدي نفس الفعل، أما كاهن shd فقد ظهر بمشه جنازة "مونتو -حر -خبش.إف" ينظم مشية فريق السحب ومنهم الثيران. DAVIES, The Tomb of Antefoker, PL.XXII; WILlEMS, The Coffin of Heqata, FIG.68; MASPERO, Montouhikhopshouf, 441. 
يظهر التباين الزمني خلا الدولة الحديثة حيث شهد هذا العصر تطوراً في مشهد المانشية المشاركة

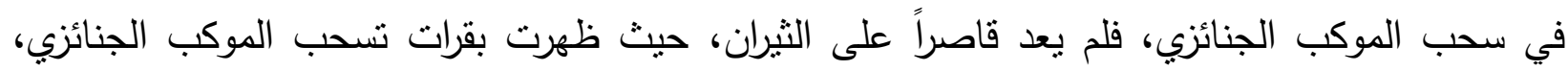

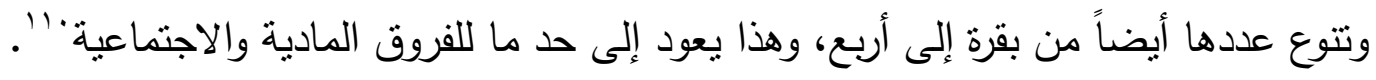

يبدو أن هناك تبايناً أكثر أهمية من التباين المادي والاجتماعي في اختيار ماشية سحب الموكب، ألا

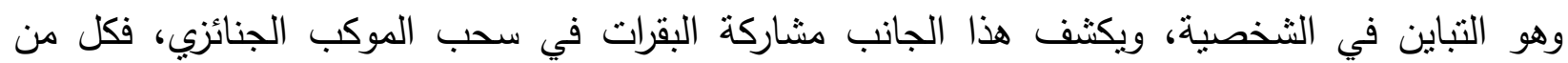

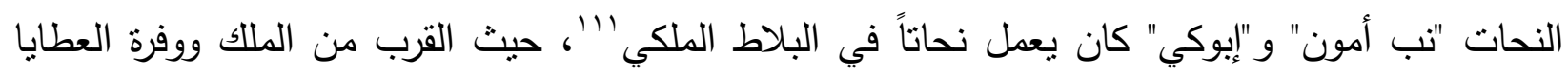

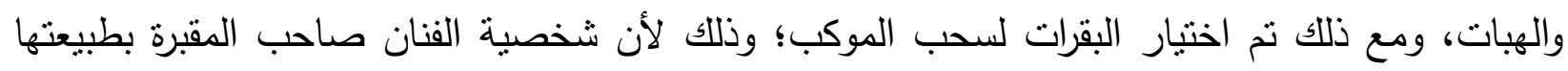

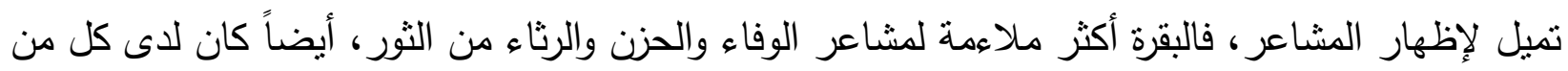
"تب أمون" و "إبوكي" رغبة في ابتكار شكل جديد للنادبنين.

كان "نفر -حتب" صاحب مال ومكانة اجتماعية، حيث كان الكاتب العظيم لأمون، لكنه كان أيضاً المشرف على ثيران وبقرات أمون، ومن خلال تلك الكتابة النادرة لكلمة

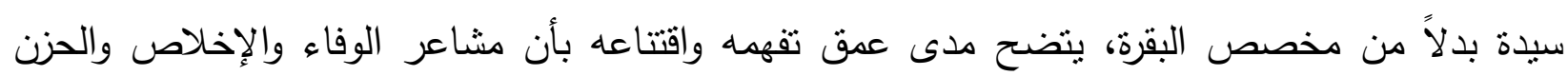
أوضح وأعمق عند الإناث من الذكور ؛ لذا فضل مشهـ البقرات في موكبه الجنائزي عن الثيران.

فضل "وسر" كاتب ومشرف أراض أمون ب" مشهح البقرات وهذا نابع من شخصيته وطبيعة عمله بين

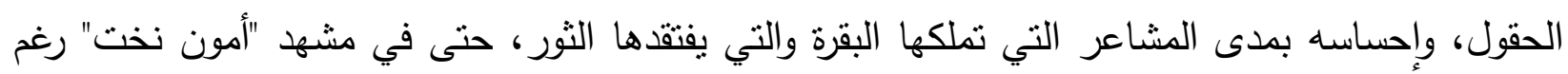

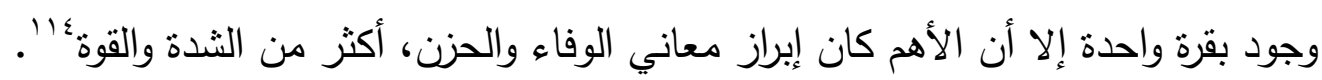

بناء على ذلك أضفت البقرات المشاركة في سحب الموكب طابعاً وجدانيًّا على الموكب الجنائزي،

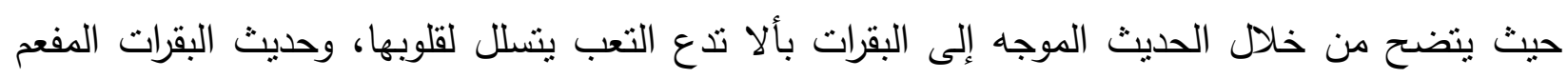

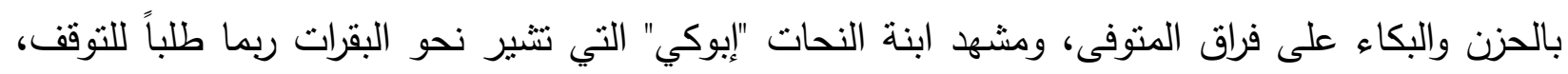

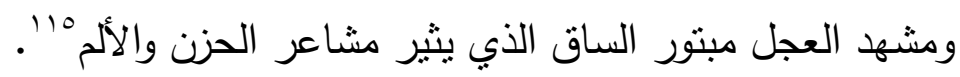

”" شاركت بقرة في جنازة " أمون-نخت" الخادم في مكان الحق، في حين شاركت بقرات أربع في جنازة " نفر -حتب" الكاتب

Noblecourt, Concubines du Mort, PL. II; DAVIES, The Tomb of Nefer-Hotep, PL. XX.

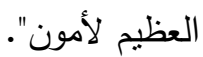

111 DAVIES, The Tomb of Two Sculptors, 13.

112 DAVIES, The Tomb of Nefer-Hotep, 17, PLS.XXX, XXXIV.

113 NASR, The Theban Tomb 260 of User, 177.

${ }^{114}$ GUILHOU, La Mutilation Rituelle de Veau, 287, 288.

115 LÜDDECKENS, Untersuchungen über Religiösen Gehalt, 83; NASR, The Theban Tomb 260 of User, 184; SCHEIL, Le Tombeau des Graveurs, PL.VII. 
- انترك كل من الثيران والأصدقاء التسعة في سحب تابوت المتوفى، ويلاحظ في مقبرة مونتو -حر خبش.إف أن ثلاثة من الثخصيات المشاركة بالموكب حلت محل ثلاثة من الأصدقاء النشعة.

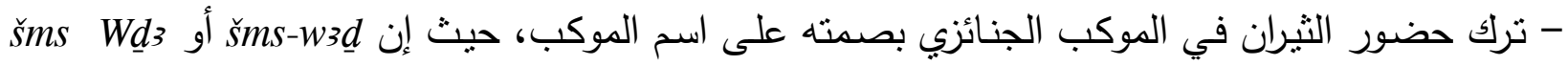
تعني " موكب (الثثران) الثنابة القوية السليمة". - طغى تصوير الثثران على مشاهد سحب التابوت خلال الدولة الحديثة عن ذي قبل، وخضع عدد الثيران المشاركة لثزاء المتوفى ومكانته الاجتماعية. - يظهر التجديد في المشاهد الجنائزية خلال الدولة الحديثة بمشاركة البقرات في سحب التابوت، وتتوع عدد البقرات وفق مكانة صاحب المقبرة. - كان لثخصية صاحب المقبرة أثر في اختيار وتحديد نوع المانشية المشاركة في سحب التابوت، حيث مال بعضهم للثيران لثنتها وقوتها، ومال البعض الآخر للبقرات لعمق تعبيرها عن المشاعر . - يغلب على مشاهد الجنازة التي يشارك في سحبها الثيران الطابع المنظم الرسمي، في حين يغلب على مشاهد البقرات الطابع الثنعبي المفعم بالحزن والرثاء. - ابتكر كل من "نب أمون" و "إبوكي" تصويراً جديداً للنادبتين إيزة ونبت- حت في شكل بقرتين. - تظهر كتابة نادرة للقب "المشرف على البقرات" بمقبرة نفر -حتب، حيث كتب مخصص nfrwt بشكل سيدة بدلاً من مخصص البقرة. - تميزت جنازة مونتو -حر -خبش.إف بالتعبير عن الحركة السريعة داخل المنظر من خلال تكرار تصوير بعض الثخصيات في مشاهد مختلفة. - يصور مشهـ جنازة حتب-حر -آخت ثورين يعبر عنهما النص بصيغة المفرد، دلالة على وحدة الاتجاه

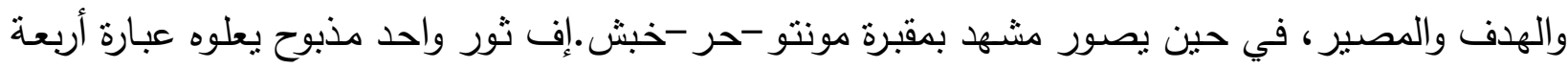
ثيران حمراء، دلالة على اختصار مساحة التصوير وعدم التكرار ، من خلال نص مختصر ومعبر . - أثنتق اسم الثور ng من الفعل ng3 " يذبح"، واستخدمت إناثه في الحلب وفي سحب الموكب حيث ظهرت

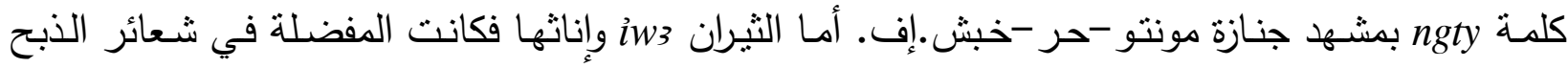
والتضحية.

- شارك الثثران والأبقار في الموكب الجنائزي بأسماء أخرى معبرة عن جنسها أو صفاتها. 
- كان للون الأحمر للثيران رمزية تربط بينه وبين المعبود ست قاتل أوزير ، حيث يعاقب ست بسياط قائد الثثران، ويذبح ويقدم لأوزير كقربان. - اللون الأحمر للبقرات لم يكن رمزاً للعقاب، بل رمزاً للانتصار على الثر وتجدد ميلاد أوزير . - يعكس اللون الأسود للبقرات حالة الحزن الداخلية للبقرات على فراق صاحبها. - ظهر العجل مشوه أو مبتور الساق بالموكب الجنائزي ليعكس حادثة قطع إيزة ليد حور عقب تلوثها بمني

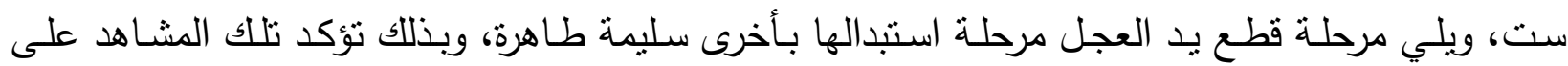
سلامة العجل المشارك في الموكب، وطهارته من أي دنس يديء بله إليه. - أستخدم لبن البقرات المشاركة في تطهير طريق الجنازة، وتطهير فم أوزير. - يناظر ناثر اللبن أمام الموكب الجنائزي ناثز المـاء الذي صور كثيراً أمام زحافة التمثال خـلال الدولة

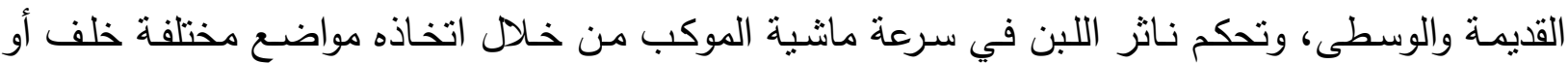

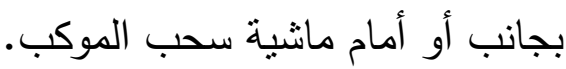
- تحكم الكاهن dِ shl ويعني لقبه " المفتش" في حركة الموكب والماشبة من خلال عصي بمسك بها ويضرب بإحداها على الأخرى فينظم مشية الموكب والماثية من خلا إيقاع الصوت. 


\section{ثبت المصادر والمراجع}

\section{أولاً: المراجع العربية والمعربة:}

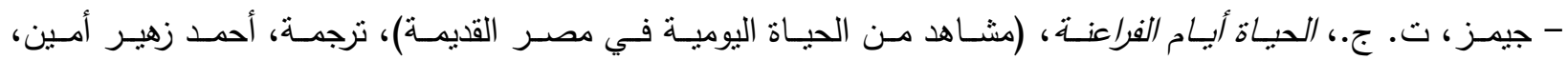
القاهرة، 199 (

- GĪMZ, T. G., al-ḥyāa ayām al-frā' ina ,Mašāhd min al-ḥyāa al-yaūmīya fì Miṣr al-qadīma, Translated by: Ahmad Zhīr Amīn , Cairo,1997.

-نور الدين، عبد الحليم، الديانة الدصرية القديمة، (الكهنوت والطقوس الدينية) ، جـ. ؟، القاهرة، 9 ـ . ؟.

- Nūr AL-DīN, 'ABD-AL-HALī̀M, al-dīyāna al-mișrīya al-qdīma, al-kahanūt wa'l-țqūs al-dīnīya ,2 , Cairo, 2009.

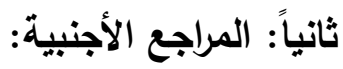

-Al-AyedI, A. R., Index of Egyptian Administrative, Religious and Military Titles of the New Kingdom, Ismailia, 2006.

- AltenMulleR, H.: «Bestattungsritual», In LÄ, 1, edited by Helck, W. \& Otto, E., 746-765, Wiesbaden, 1984.

-AssmanN, J., Death and Salvation in Ancient Egypt, USA, 2005.

- AYAD, M. F., God's Wife, God's Servant, the God's Wife of Amun (C.740-525 BC), London, 2009.

-BAUD, M. \& FAROUT, D.: «Trois Biographies d'Ancien Empire Revisitées», BIFAO 101, Le Caire, 2001, 43-57.

- BLACKMAN, A. M., The Rock Tombs of Meir, II, London, 1915.

- BRUYERE, B., Rapport sur les Fouilles de Deir el Médineh, V, Le Caire, 1928.

-DAVIES, B. G., Who's Who at Deir el-Medina, Leiden, 1999.

- DAVIES, N. G., The Rock Tombs of Deir El Gabrawi, II, London, 1902.

- ................. Five Theban Tombs, London, 1913.

- ................ The Tomb of Amenemhet, London, 1915.

-............ The Tomb of Antefoker Vizer of Sesostris I and of his Wife Senet №.60, London, 1920.

- ............ The Tomb of Two Sculptors at Thebes, New York, 1925.

The Tomb of Nefer-Hotep at Thebes, I, New York, 1933.

The Tomb of Rekh-mi-Re at Thebes, II, New York, 1943.

Seven Private Tombs at Kurnah, London, 1948.

- DE-BUCK, A., The Egyptian Coffin Texts, II, Chicago, 1947.

-.......... The Egyptian Coffin Texts, III, Chicago, 1947.

The Egyptian Coffin Texts, IV, Chicago, 1951. 
-DiAmOND, K. A.: «The Placement of the Sacred District Scene in the Rectangular Tombs at Elkab», JARCE 48, Cairo, 2012, 97-110.

- DZIOBEK, E., Das Grab des Ineni Theben N Nr.81, Mainz, 1992.

- EATON-KRAusS, M., The Representations of Statuary in Private Tombs of the Old kingdom, Wiesbaden, 1984.

- El-ShahawY, A., The Funerary Art of Ancient Egypt, a Bridge to the Realm of the Hereafter, Cairo, 2006.

-............ Recherche sur la Décoration des Tombes Thébaines du Nouvel Empire, London, 2010.

- FAulKner, R. O., The Ancient Egyptian Coffin Texts, I, England, 1973.

-.......... A Concise Dictionary of Middle Egyptian, Oxford, 1991.

- FISCHER, H. G., Egyptian Studies III, Varia Nova, New York, 1996.

- FORSHAW, R., The Role of the Lector (hry-ḥbt) in Ancient Egyptian Society, Manchester, 2013.

- Gardiner, A., The Chester Beatty Papyri №. I, Oxford, 1931.

- GeIsEn, C., The Ramesseum Dramatic Papyrus a New Edition, Translation, and Interpretation, Toronto, 2012.

- GomeZ, G. M.: «La Procesión Funeraria de la Tumba de Hery (TT 12) en Dra Abu el-Naga», BAEDE 15, 2005, 29-65.

- GoyON, J. C., Rituels Funéraires de l'Ancienne Égypte, Paris, 1972.

- Guilhou, N.: «La Mutilation Rituelle de Veau dans le Scènes de Funérailles au Nouvel Empire», BIFAO 93, 1993, 277-298.

- Hammad, M. B. \& Mohamed, Y. A.: «Milk Vessels in Ancient Egypt», IAJFTH 3, Cairo, 2017, 1-46.

- HART, G., Dictionary of Egyptian Gods and Goddesses, London, 2005.

-HASSAN, S., Excavations at Giza 1932-1933, IV, Cairo, 1943.

- HelCK, W., Untersuchungen zu den Beamtentiteln des Ägyptischen Alten Reiches, New York, 1954.

- HermanN, A., Die Stelen der Thebanischen Felsgräber der 18 Dynastie, New York, 1940.

- IVANOVA, M., Milk in Ancient Egyptian Religion, Uppsala, 2009.

- JimÉneZ-Serrano, A \& Morales, A. J.: Middle Kingdom Palace Culture and its Echoes in the Provinces Regional Perspectives and Realities, Leiden, 2021.

- JONES, D., An Index of Ancient Egyptian Titles, Epithets, and Phrases of the Old kingdom, I, Oxford, 2000.

- JUNKER, H.: «Die Schlacht und Brandopfer im Tempelkult der Spätzeit», Z ̈̈S 48, Berlin, 1911, 69-77.

Grabungen auf dem Friedhof des Alten Reiches bei den Pyramiden von Giza, II, Leipzig, 1934.

- KITCHEN, K. A., Ramesside Inscriptions Historical and Biographical, III, Oxford, 1980. 
- LD = LEPSIUS, C. R., Denkmäler aus Ägypten und Äthiopien, II, Berlin, 1849-1858.

- LEITZ, C., Lexikon der Ägyptischen Götter und Götterbezeichnungen, VII, Belgium, 2002.

- LESKO, L. H., Pharaoh's Workers the Villagers of Deir el Medina, London, 1994.

- LiCHTHEIM, M.: «Situla №. 11395 and Some Remarks on Egyptian Situlae», JNES 6, 1947, 169179.

Ancient Egyptian Literature, I, London, 1973.

- LÜDDECKENS, E.: «Untersuchungen über Religiösen Gehalt, Sprache und form der Ägyptischen Totenklagen», MDAIK 11, 1943, 1-188.

- MAsPero, G., Les Mastabas de L'Ancien Empire, Paris, 1889.

- ........ : «Le Tombeau de Montouhikhopshouf», MMAF 5, 1894, 435-468.

-Mekhitarian, A., The Great Centuries of Painting, Egyptian Painting, II, Brussels, 1957.

- MOHR, H. T., The Mastaba of Hetep-her-akhti, Leiden, 1943.

- Moret, A.: «La Légende d'Osiris à l'Époque Thébaine d'après l'Hymne à Osiris du Louvre», BIFAO 30, Le Caire, 1930, 725-750.

- NASR, M. W.: «The Theban Tomb 260 of User», SAK 20, Hamburg, 1993, 173-202.

- Noblecourt, C. D.: «Concubines du Mort et Mères de Famille au Moyen Empire», BIFAO 53, 1953, 7-47.

- OTTO, E.: «An Ancient Egyptian Hunting Ritual», JNES IX, Chicago, 1950, 164-177.

- OWUSU, H., Egyptian Symbols, London, 2000.

- PINCH, G.: "Red Things the Symbolism of Colour in Magic", In Colour and Painting in Ancient Egypt, 182-185, London, 2001.

$-P M=$ PORTER, B. \& MOsS, R. L. B., (eds.), Topographical Bibliography of Ancient Egyptian Hieroglyphic Texts, Reliefs and Painting, II,V, Oxford, 1994.

- RobINS, G.: «Color Symbolism», In The Encyclopedia of Ancient Egypt Oxford, 291-294, Oxford, 2001.

-Pyr = SETHE, K., (eds.) Die Altägyptischen Pyramidentexte, 1-IV, Leipzig, 1910.

- SCHEIL, V.: «Le Tombeau des Graveurs, in Tombeau Thébains», MMAF 5,1894, 555-596.

- SETHE, K., Agyptische Lesestucke Texte der Mittleren Rreiches, Leiptzig, 1959.

-SETTGAST, J., Untersuchungen zu den Altägyptischen Bestattungsdarstellungen, New York, 1963.

- SIMPSON, W. K., The Mastabas of Qar and Idu G7101 and 7102, Boston, 1976.

- SMITH, H. S.: "Animal Domestication and Animal Cult in Dynastic Egypt", In The Domestication and Exploitation of Plants and Animals, 307-314, New York, 2017.

- SOUKIASSIAN, G.: «Une Version des Veillées Horaires d'Osiris», BIFAO 82, 1982, 333-348. 
- STEVENS, J., Le Tekenou et son Implication dans les Rites Funéraires de l'Égypte Ancienne, Louvain, 2020.

- STÖRK, L.: “Rind”, In LÄ, V, edited by Helck, W. \& Otto, E., 257-263, Wiesbaden, 1984.

- STRUDWICK, N., The Administration of Egypt in Old kingdom, London, 1985.

- TASSIE, G. J.: «Bulls, Hair and the Teknu: An Enigmatic Egyptian Custom Revisited», PIA 11, 2000, 27-46.

-TeETER, E., Religion and Ritual in Ancient Egypt, New York, 2011.

- TE VELDE, H., Seth God of Confusion, Leiden, 1967.

- The Epigraphic Survey, The Festival Procession of Opet in the Colonnade Hall, OIP 112, Chicago, 1994.

- TYLOR, J. \& GRIFFITH, F.: The Tomb of Paheri at el Kab, London, 1894.

- Wb = ERMAN, A. \& GRAPOW, H. (eds.), Wörterbuch der Ägyptischen Sprache, I,II,V, Leipzig: J. Hinnrichs, 1926-1931.

- WiLKINSON, J. G., The Manners and Customs of the Ancient Egyptians, II, New York, 1878.

- WiLKINSON, R. H., Symbol and Magic in Egyptian Art, London, 1994.

- WiLKINSON, T. A. H., Early Dynastic Egypt, London, 1999.

- WiLlems, H., The Coffin of Heqata (Cairo JdE 36418), Louvain, 1996.

-WILSON, J. A.: «Funeral Services of the Egyptian Old kingdom», JNES 3, 1944, 201-218.ZANDEE, J., "Death as an Enemy", in Studies in the History of Religions, Leiden, 1960. 


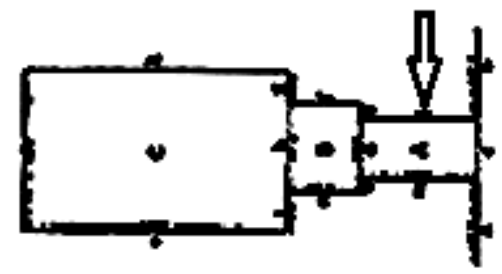

(ثكل () الممر الأول-الجدار الثمالي- مقبرة-حتب-حر -آخت-سقارة.

MOHR, The Mastaba of Hetep-her-akhti, 25.

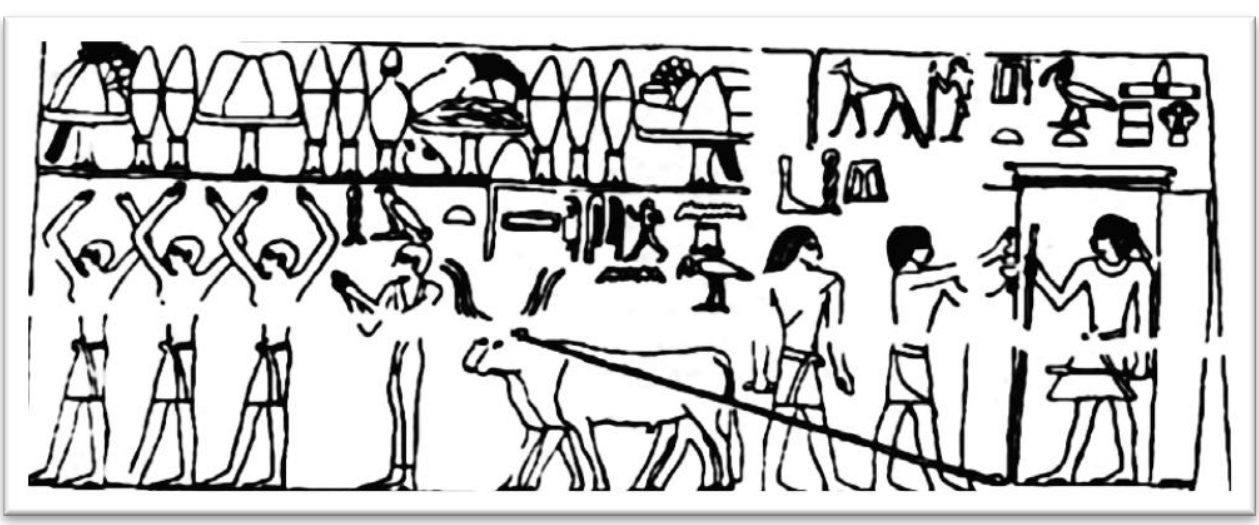

(شكل r) ثوران لونهما أحمر يسحبان تمثال المتوفي- مقبرة-حتب-حر -آخت- سقارة.

MOHR, The Mastaba of Hetep-her-akhti, FIG.3.

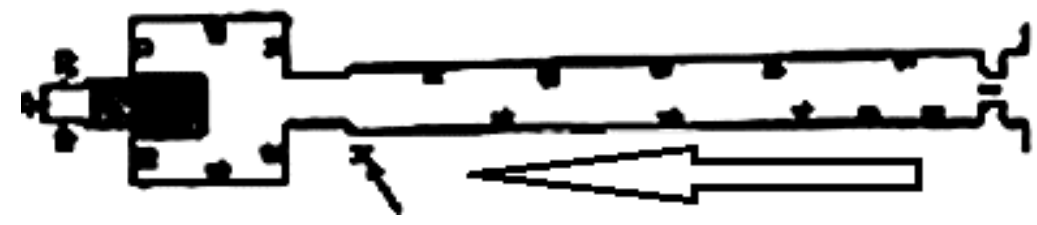

(ثكل r) الجدار الجنوبي للمر -مقبرة إنتف-إقر - جبانة شيخ عبد القرنة

PM. I, 106.

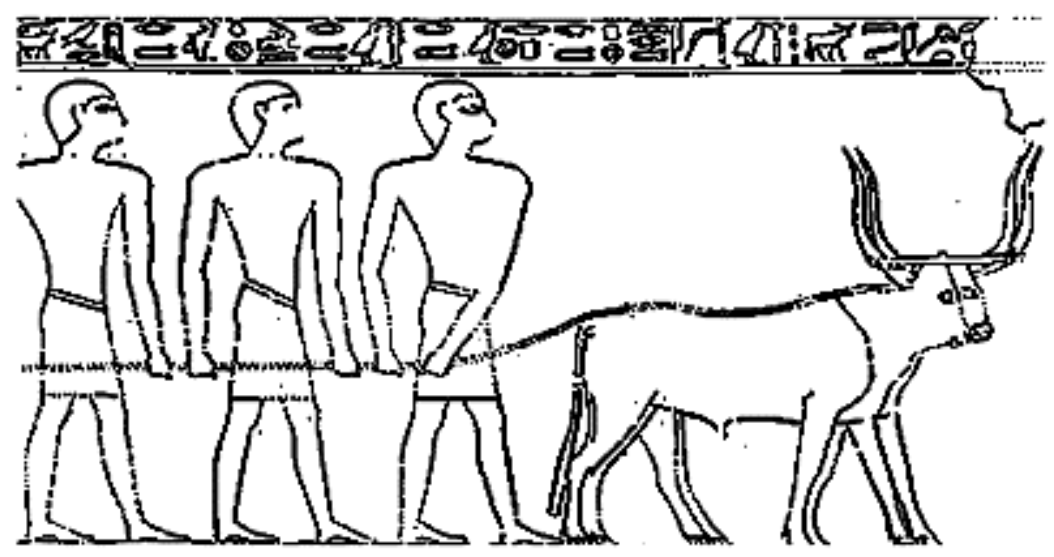

(شكل \& أ) ثيران شابة نسحب تابوت - إنتف-إقر - جبانة شيخ عبد القرنة

DAVIES, The Tomb of Antefoker Vizer of Sesostris I, PL.XXIII. 


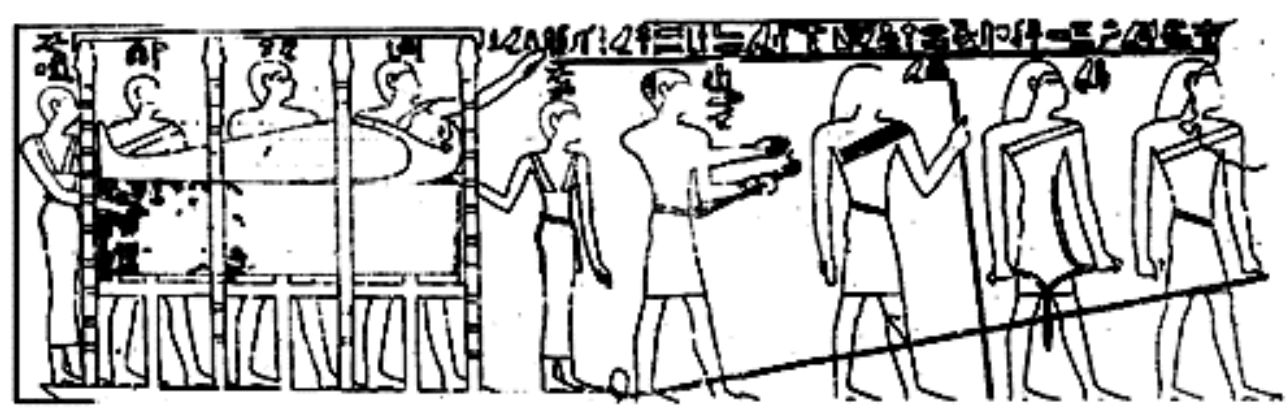

( شكل ع ب) الموكب الجنائزي - مقبرة إنتف-إقر - جبانة شيخ عبد القرنة

DAVIES, The Tomb of Antefoker Vizer of Sesostris I, PL.XXII.

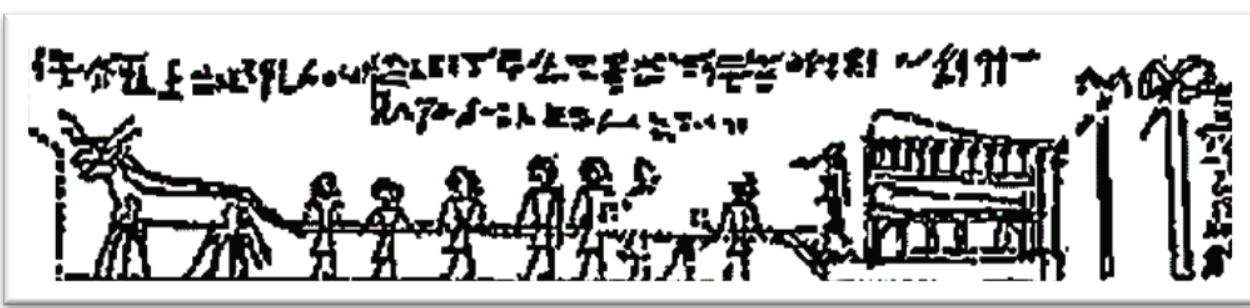

JE 36418- شكل 0) تابوت حقات - المتحف المصري

WILLEMS, The Coffin of Heqata, FIG.68.

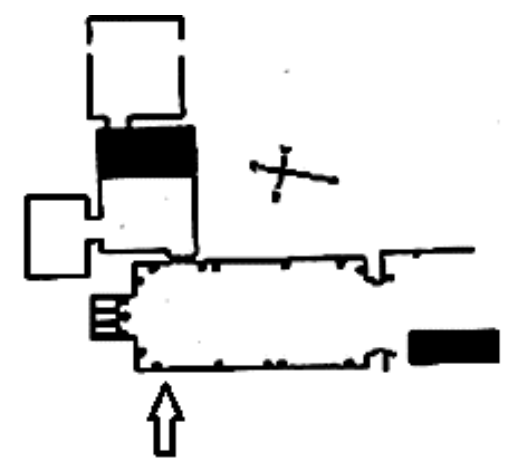

(شكل 7$)$ الجدار الغربي- الصف العلوي - الصالة- مقبرة با-حري في الكاب

PM. V, 178.

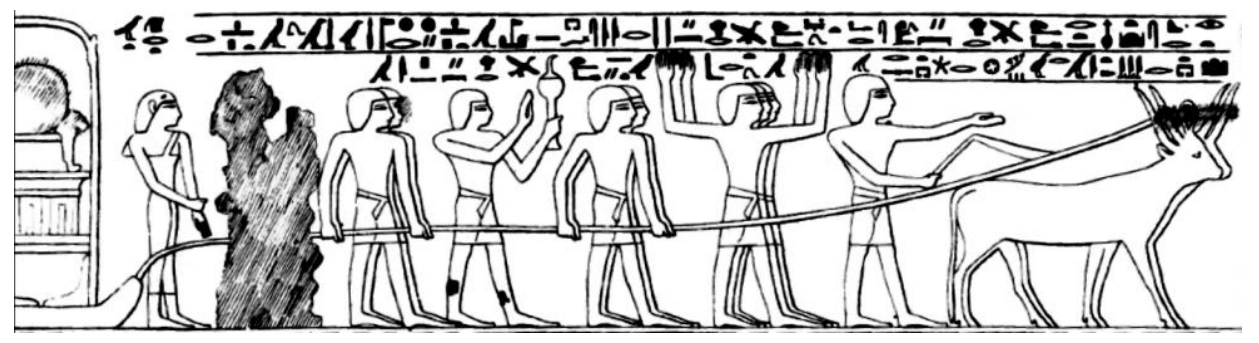

$$
\text { (شكل v أ) ثيران تسحب نابوت با-حري-في الكاب }
$$

TYLOR, \& GRIFFITH, The Tomb of Paheri at el Kab, PL.V. 


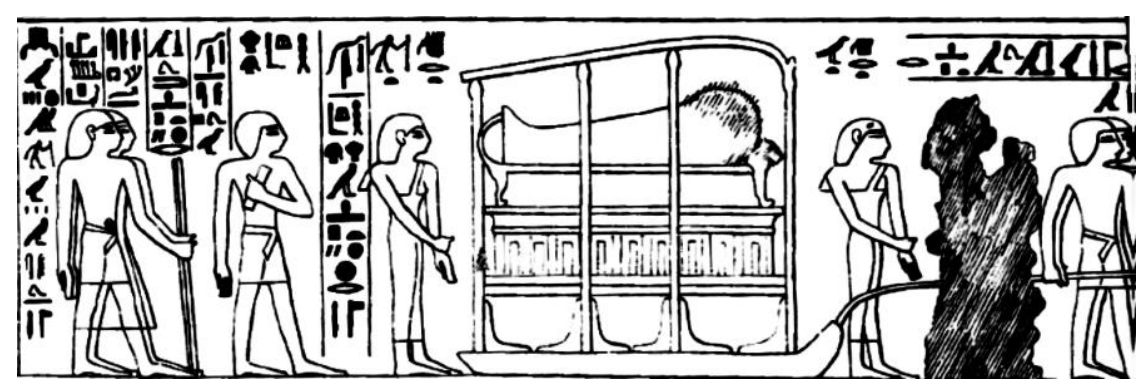

$$
\text { (شكل V بحيط بتابوت با-حري إيزة ونبت -حت ورجال الطبقات المرموقة }
$$

TYLOR, \& GRIFFITH, The Tomb of Paheri, PL.V.

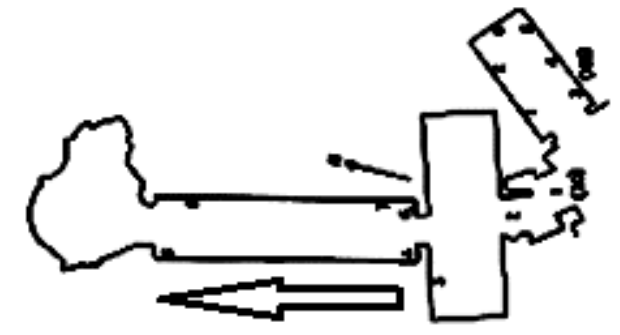

(شكل ^) الجدار الجنوبي- الحجرة الداخلية مقبرة مونتو -حر -خبش.إف - جبانة ذراع أبو النجا

PM. I, 30

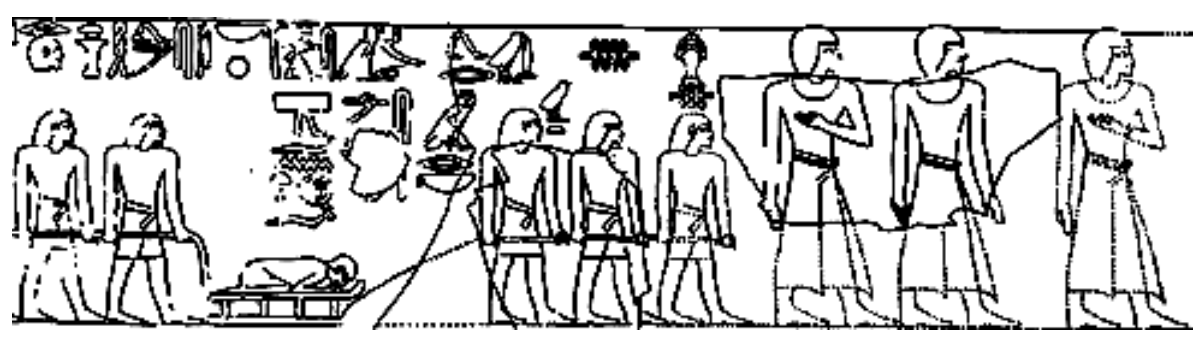

$$
\text { (تشكل 9) كهنة يسحبون التكنو - بداية الموكب الجنائزي بمقبرة مونتو -حر -خبش.إف }
$$

DAVIES, Five Theban Tombs, PL.II.

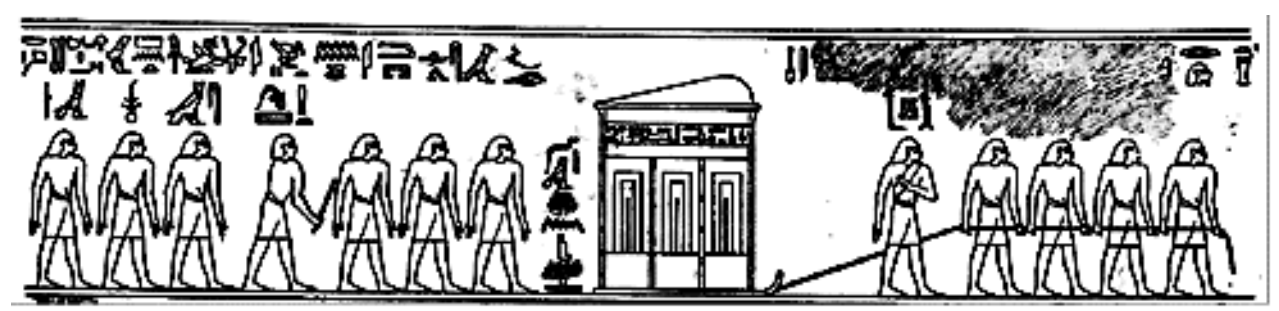

(شكل · (1) سحب ناووس به زيوت ستستخدم في شعائر الدفن، ونص يشير إلى ثورين لونهما أحمر يسحبان التابوت من منزل

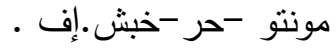

MASPERO, «Montouhikhopshouf», 439, FIG. 2. 


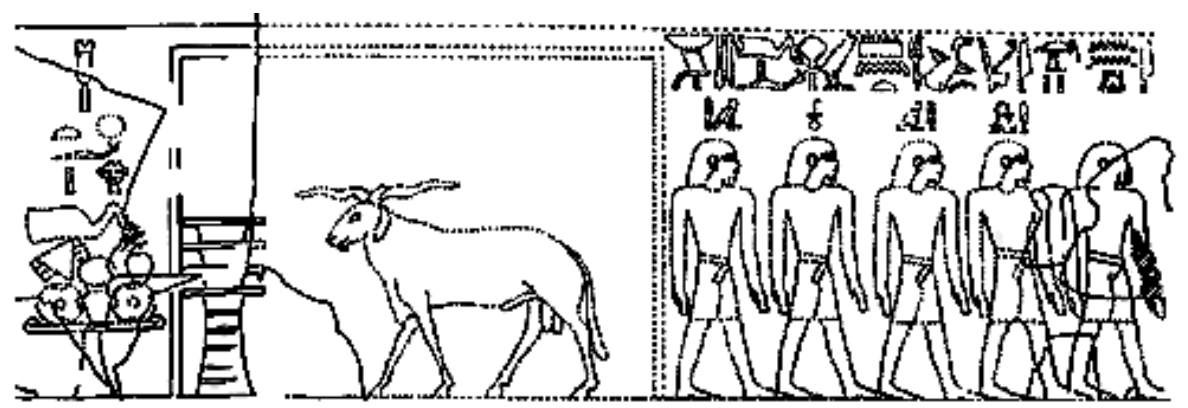

(شكل (1) كبش منديس وعمود جد وأمامه مائدة قرابين

DAVIES, Five Theban Tombs, PL.II.

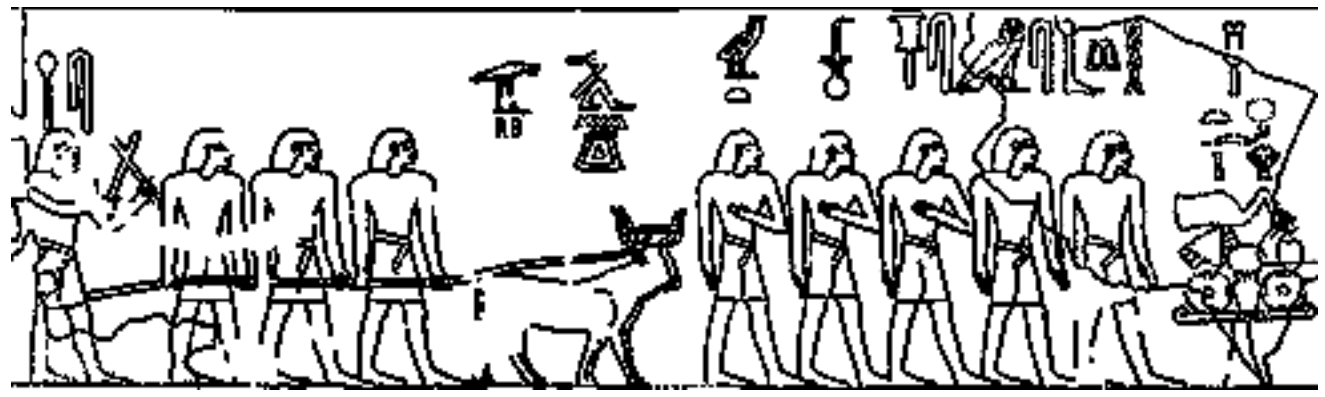

(نثكل r I ) فريق الثثران الأول مكون من ثورين لونهما أحمر

DAVIES, Five Theban Tombs, PL.II.

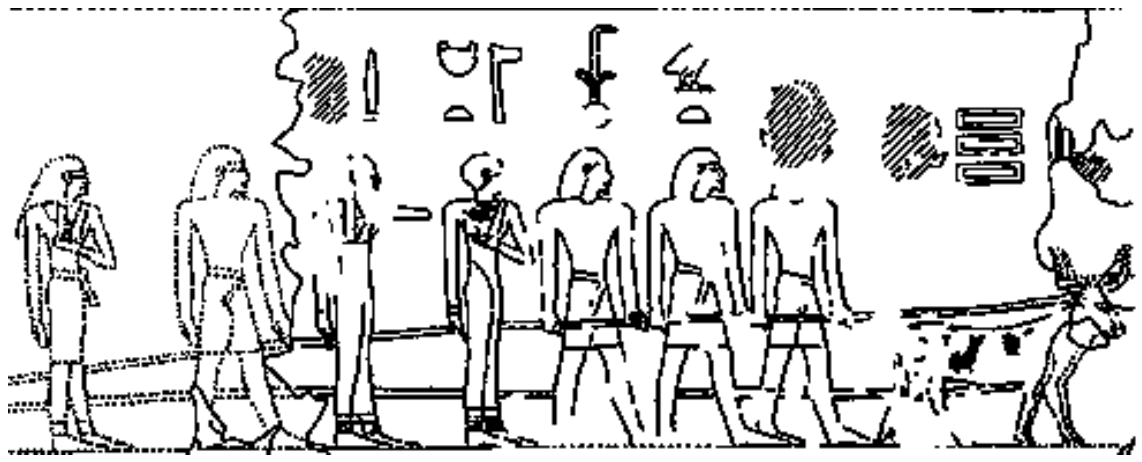

(شكل س ا ( فريق الثثران الثاني يتبعه الكهنة والنادبة الصغرى

DAvIES, Five Theban Tombs, PL.II.

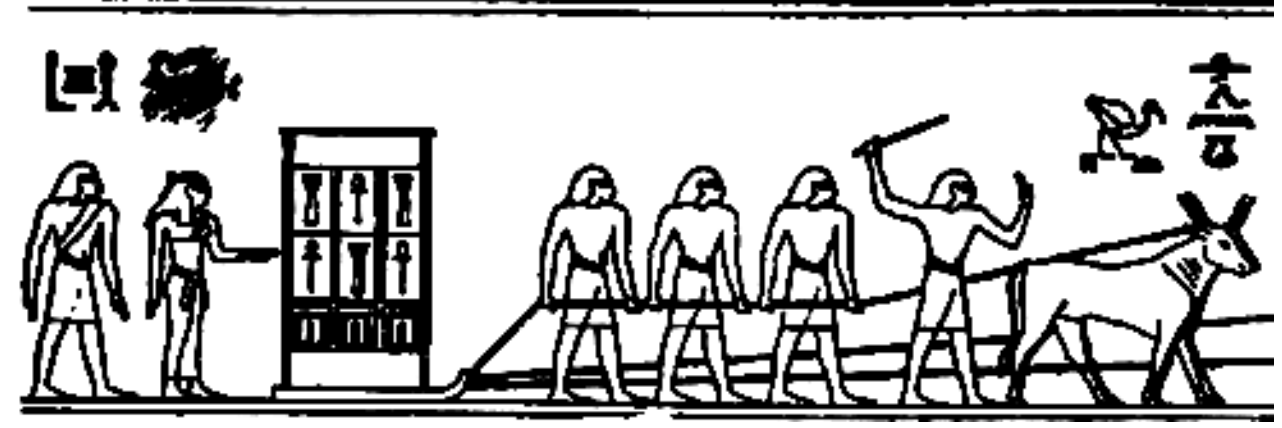

(شكل 乏 ( ) الفريق الثالث من الثيران مكون من ثورين لونهما أحمر وخلف التابوت النادبة الكبرى والكاهن المرتل MASPERO, Montouhikhopshouf, 441, FIG. 4. 


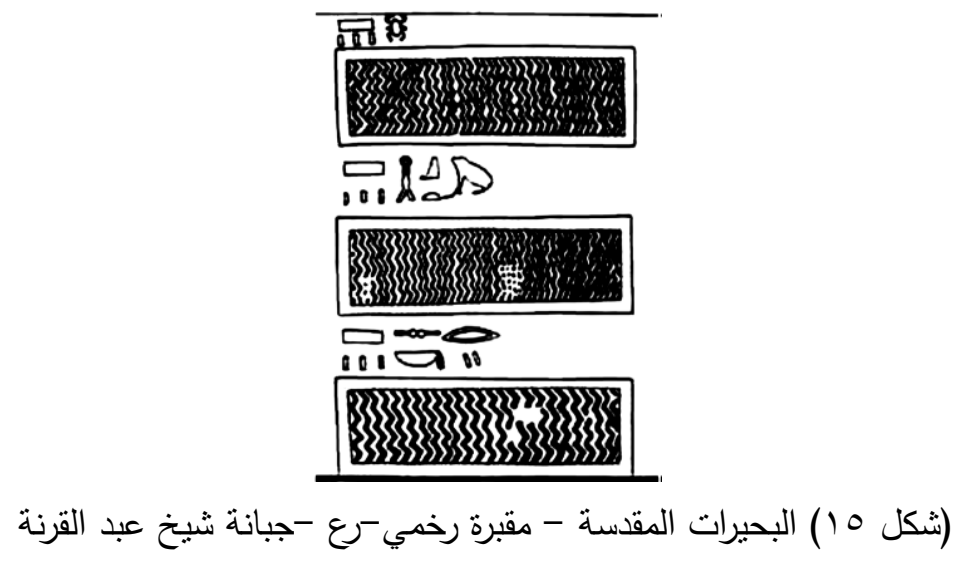

DAVIES, The Tomb of Rekh-mi-Re at Thebes, PL.LXXXVII.

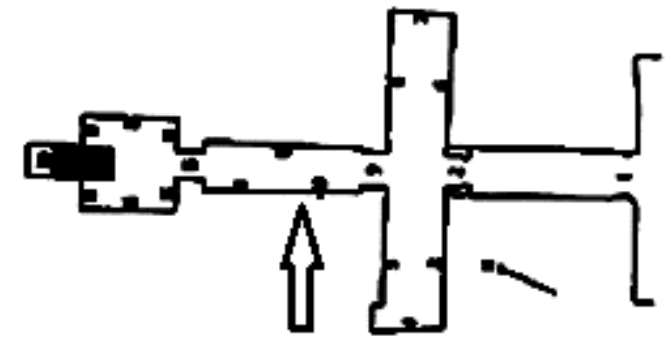

(شكل 7 (1) الجدار الجنوبي - الصالة الطولية-مقبرة أمنمحات- جبانة شيخ عبد القرنة PM. I, 160.

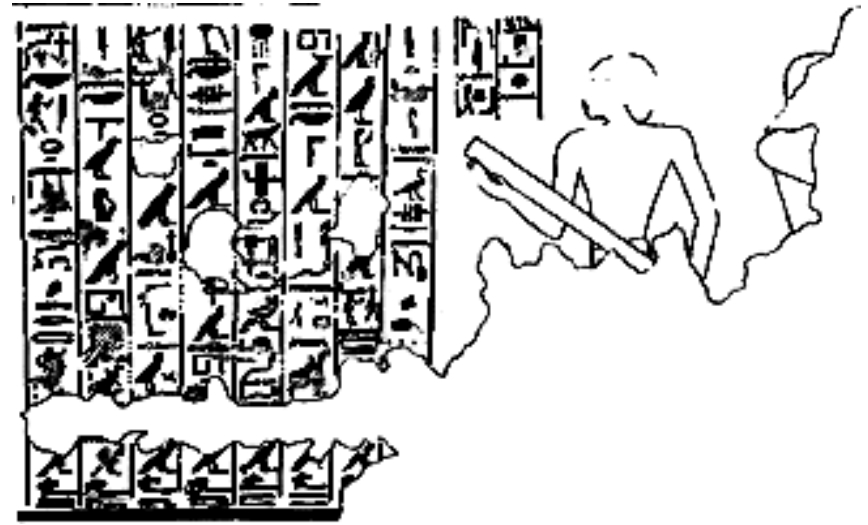

(أشكل V V أ) الكاهن المرتل بستقبل موكب الثيران أمام المقبرة

DAVIES, The Tomb of Amenemhet, PL. XI.

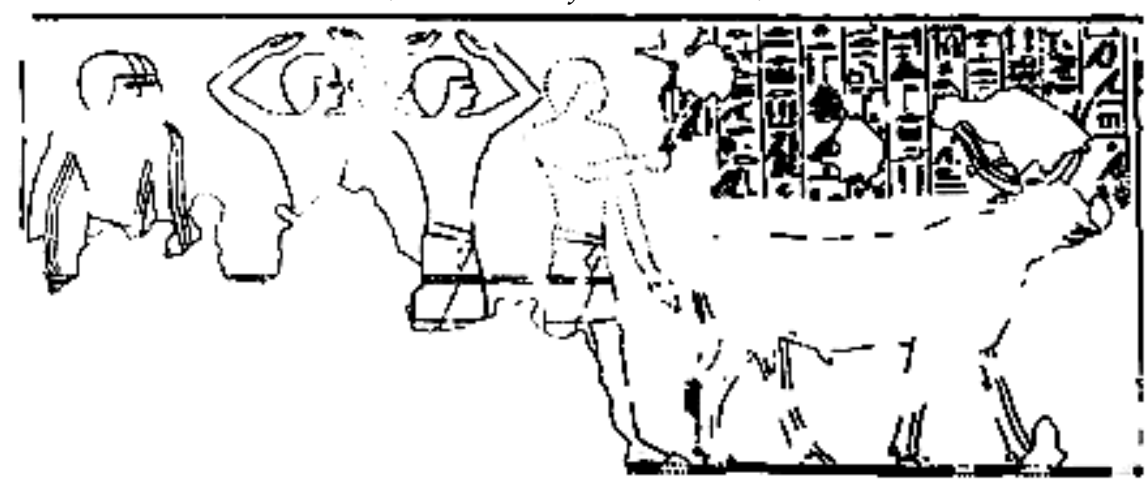

(شكل I ب) ثوران يسحبان الموكب وثلاث رجال يساهمون في سحب التابوت

DAVIES, The Tomb of Amenemhet, PL. XI. 


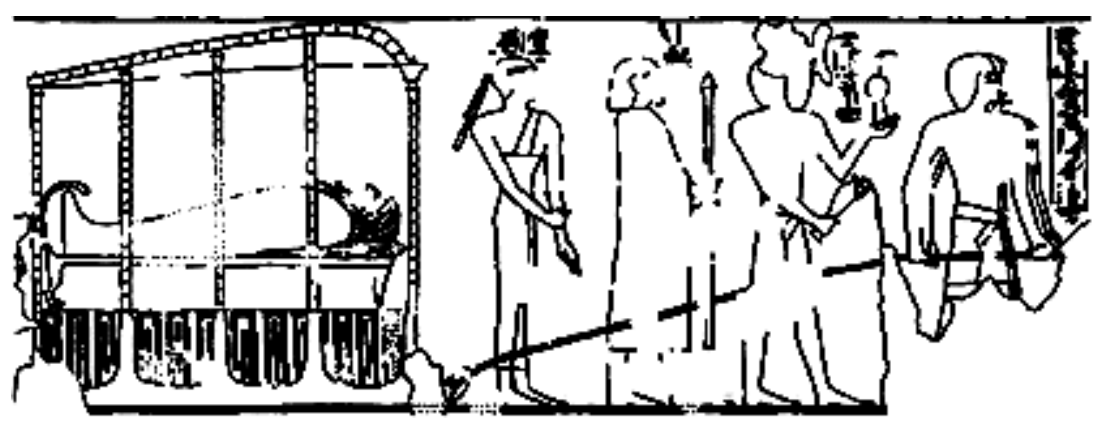

(نشكل IV) تبخير وتطهير طريق الموكب

DAvies, The Tomb of Amenemhet, PL. XII.
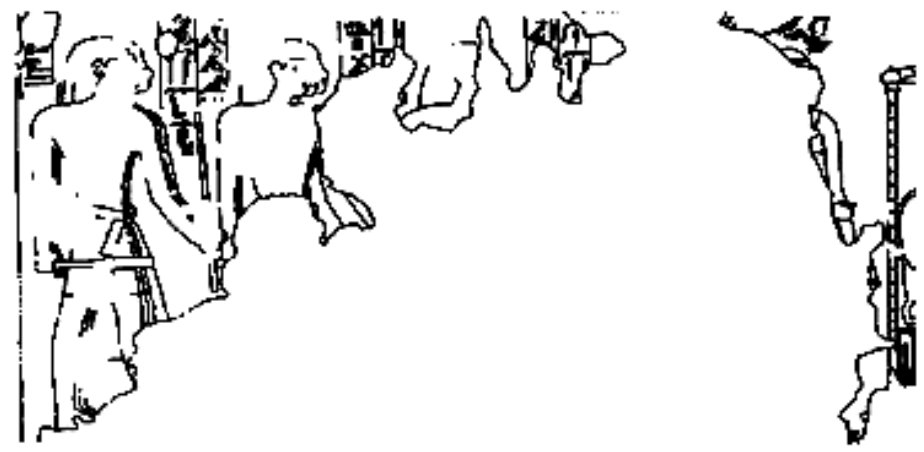

(ثكل V د I نص في نهاية الموكب يثير إلى التقدم نحو المقبرة وتنلم القرابين بين العظماء

DAVIES, The Tomb of Amenemhet, PL. XII.

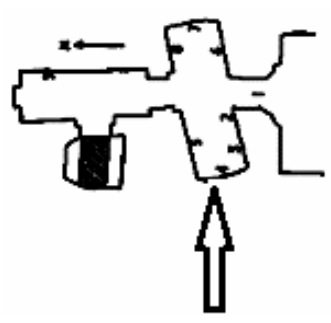

(شكل 1 1 ) الجدار الغربي -الصالة المستعرضة- مقبرة نب-أمون و إبوكي- جبانة الخوخة

PM. I., 282.

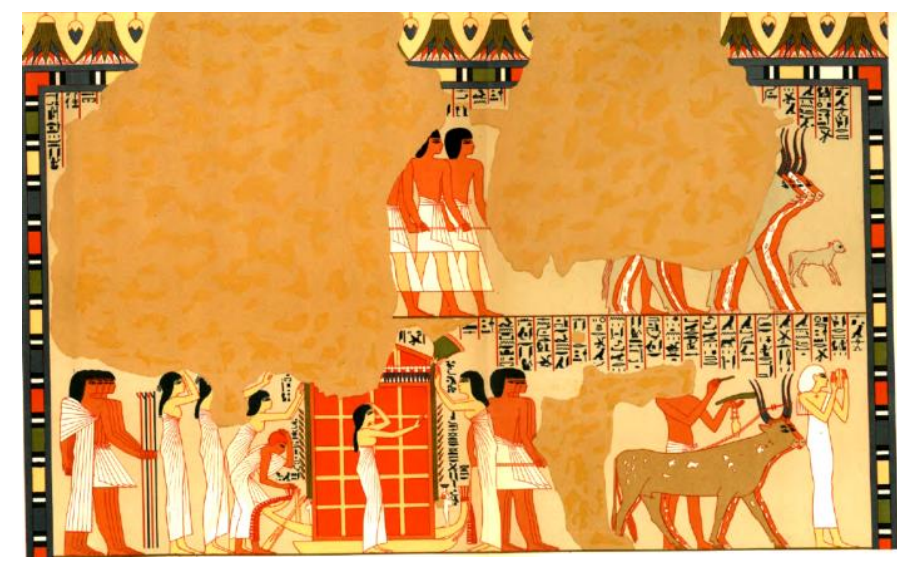

(ثكل 9 (أ) بقرات حمراء وسوداء نشارك في موكب جنائزي ينقدمها عجل، وأخرى تسحب التابوت

SCHEIL, Le Tombeau des Graveurs, PL.VII. 


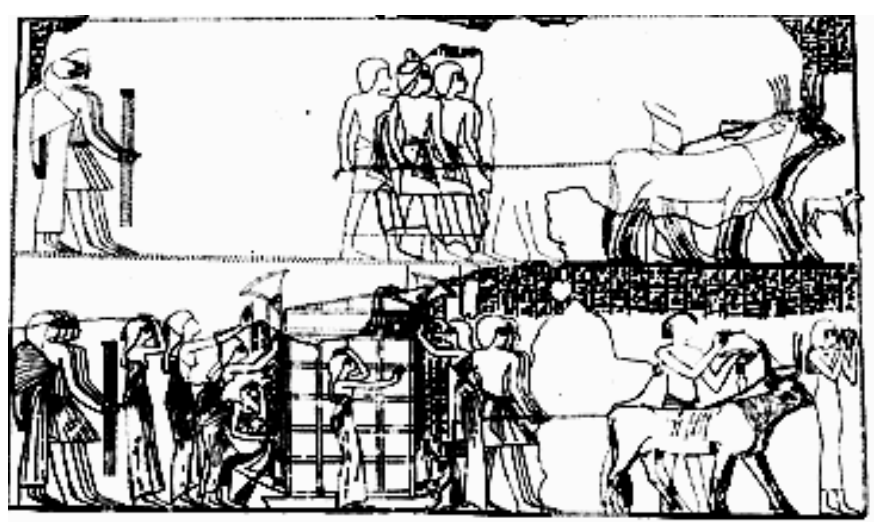

(ثكل 9 (ب) نفس المنظر السابق لكن يضيف على الموكب العلوي بعض التفاصيل مثل موضع العجل، وأقدام شخص يتقدم ثلاث رجال، ورجال من الطبقة المرموقة في نهاية الموكب.

DAVIES, The Tomb of Two Sculptors at Thebes, PL.XXII.

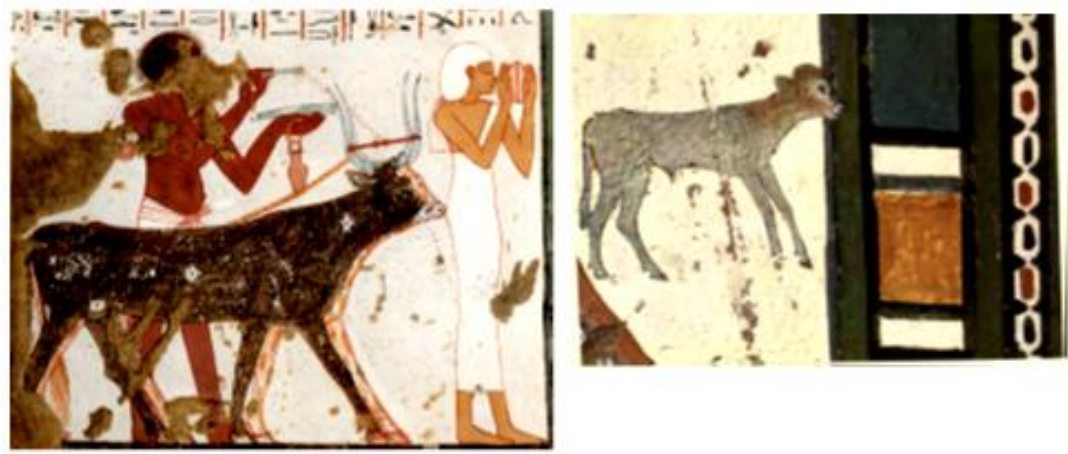

(نكل †) تفاصيل توضح تداخل رأس العجل مع الثريط المحيط بالمنظر في الموكب العلوي، كما توضح لون البقرتين الحمراء والسوداء وناثر اللبن في الموكب السفلي.

DAVIES, The Tomb of Two Sculptors, PL.XXIII; MEKHITARIAN, The Great Centuries of Painting, Egyptian Painting, 124.

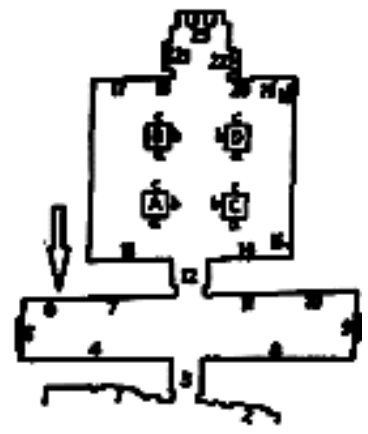

(شكل (Y) الجدار الثرقي - الصالة المستعرضة - مقبرة نفر -حتب - جبانة الخوخة

PM.I.90 

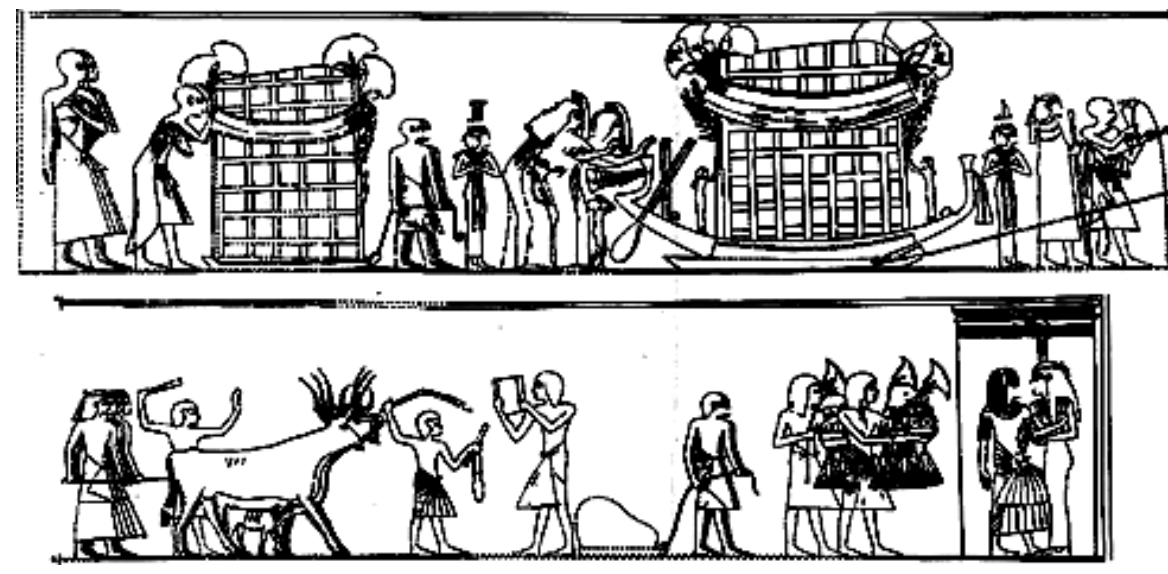

(ثكل r أ) معبودة الغرب تستقبل نفر -حتب، والكاهن المرتل وناثر اللبن أمام أربع بقرات يسحبن التابوت

DAVIES, The Tomb of Nefer-Hotep at Thebes, PL.XX.

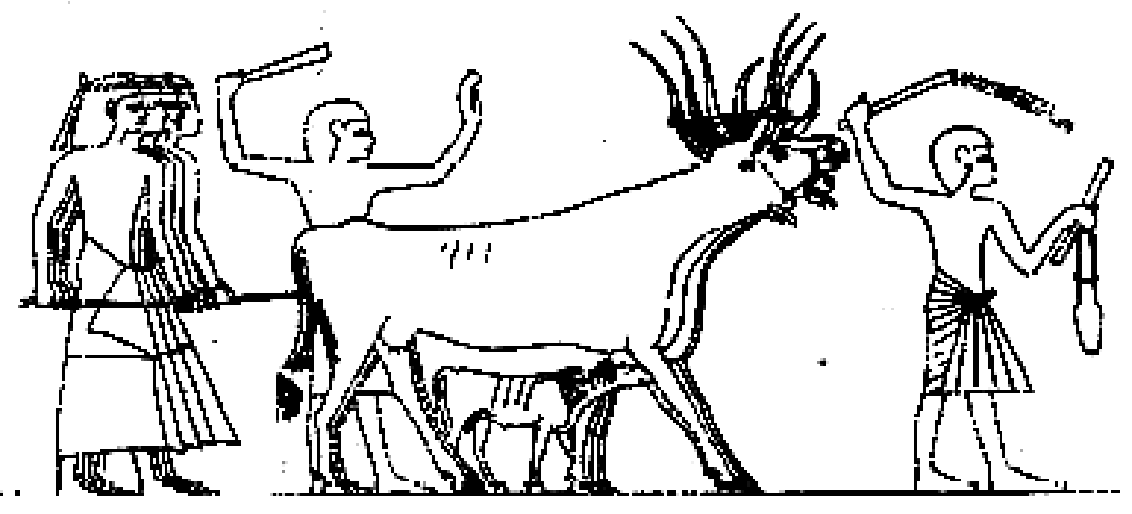

(شكل r r ب) تفاصيل للبقرات والعجل الرضيع

DAviES, The Tomb of Nefer-Hotep, PL.XX.

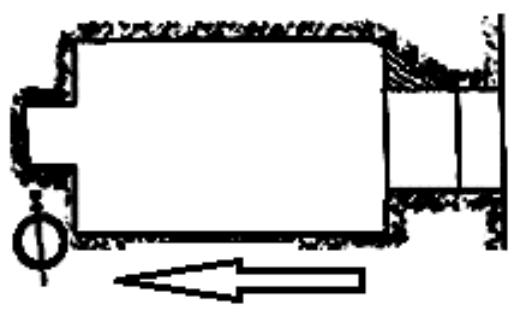

(شكل س r) الجدار الجنوبي - مقبرة وسر - جبانة ذراع أبو النجا

NASR, The Theban Tomb 260 of User, 174. 


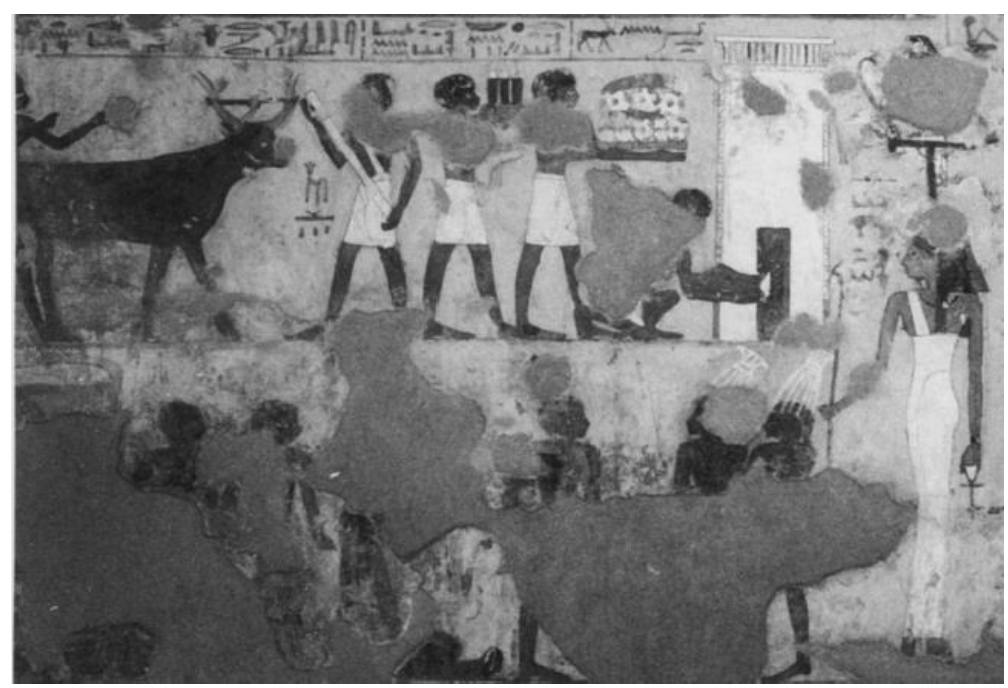

(شكل کr أ) تسنقبل معبودة الغرب الموكب الجنائزي الذي تنحبه بقرات يعلوها نص رثاء البقرات لسيدها

NASR, The Theban Tomb 260 of User, PLS.2,3.

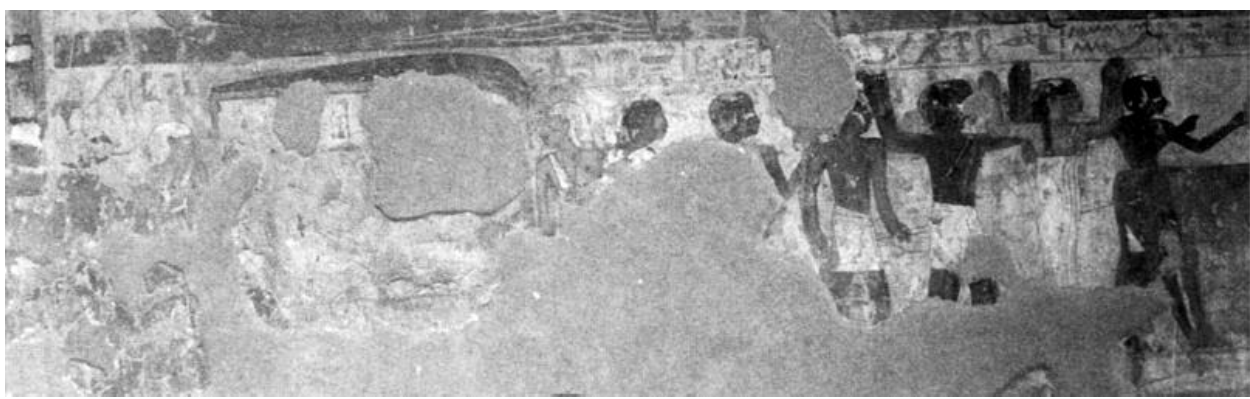

(شكل ع rب) المشاركين في الموكب الجنائزي للمتوفى وسر

NASR, The Theban Tomb 260 of User, PLS.2,3.

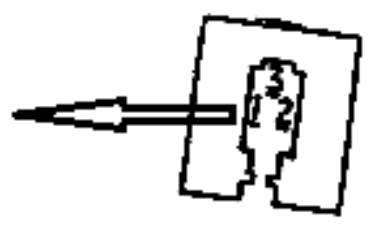

(شكل OY الجدار الجنوبي - مقبرة أمون -نخت - جبانة دير المدينة

PM, I, 318. 


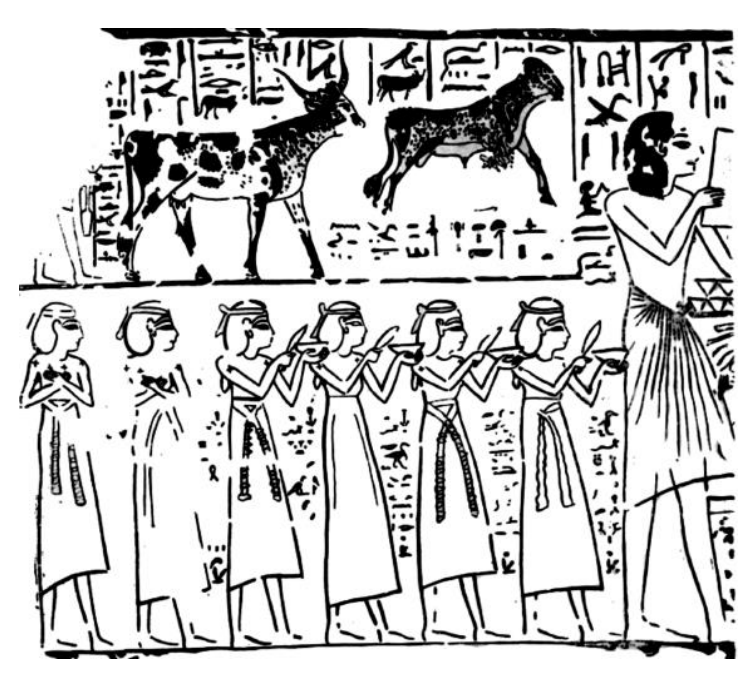

$$
\text { (شكل rY) عجل وبقرة سوداء يشاركون في الموكب،ويعلوهما نص يعبر عن بكاء البقرة على سيدها }
$$

GuILHou, La Mutilation Rituelle de Veau, FIG. 16; NOBLECOURT, Concubines du Mort et Mères de Famille au Moyen Empire, PL.II.

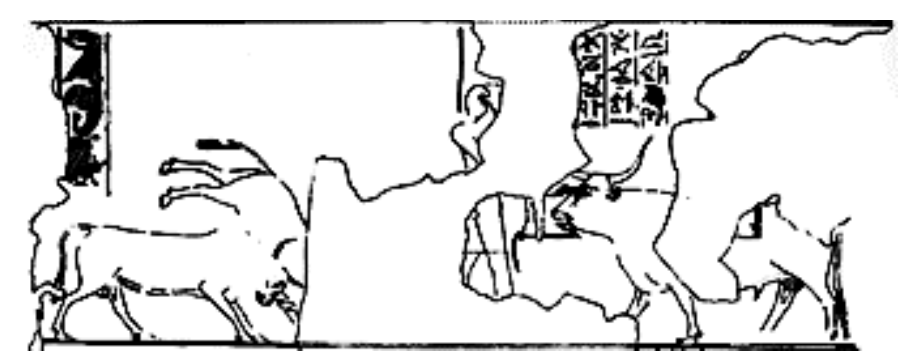

(شكل Vrriأ) نص يعكس الحالة البدنية للتور ومشهح لعراك الثثران-مقبرة أمنمحات

DAVIES, The Tomb of Amenemhet, PL.VI.

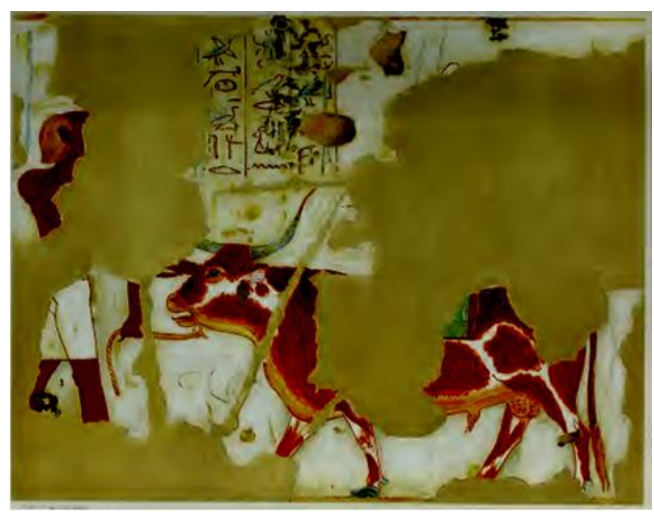

(شكل V r ب) تقاصيل تعكس القوة البدنية لنثيران الموكب الجنائزي

DAVIES, The Tomb of Amenemhet, PL. VI A. 


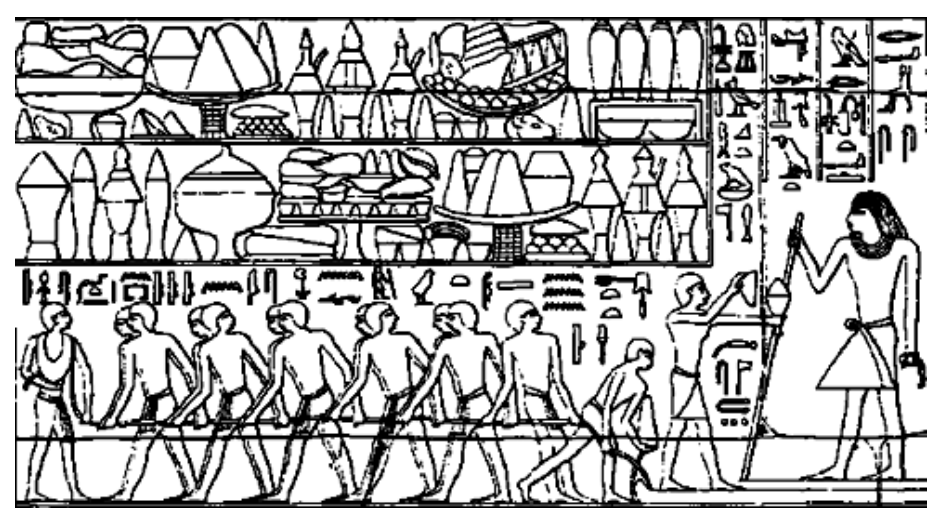

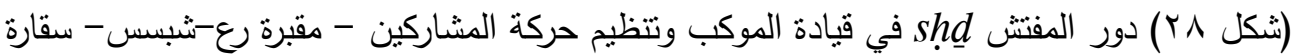

EATON-KRAUSS, The Representations of Statuary in Private Tombs of the Old kingdom, PL.XII

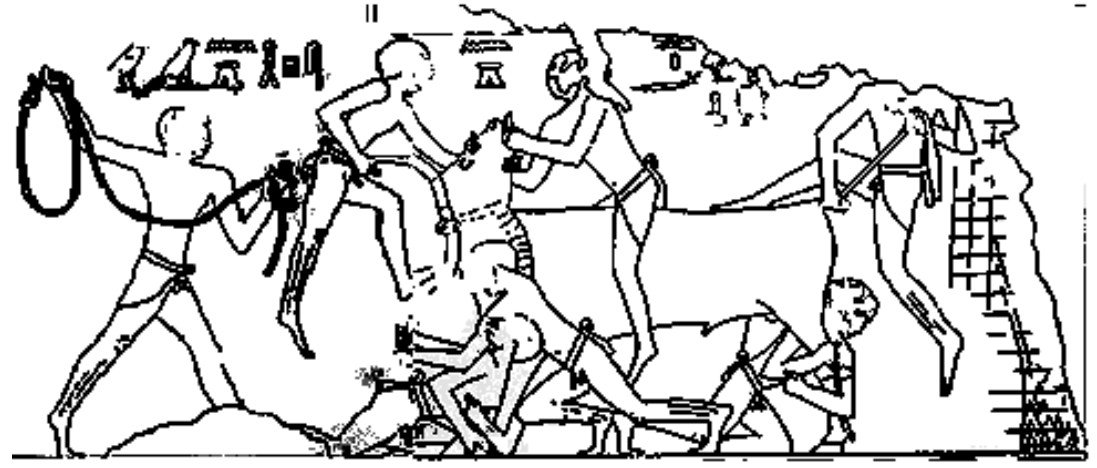

(شكل 9 Y) قنص الثور ng تمهيداً لذبحه- مقبرة سنبي - جبانة مير

BLACKMAN, The Rock Tombs of Meir, PLS. III, IV.

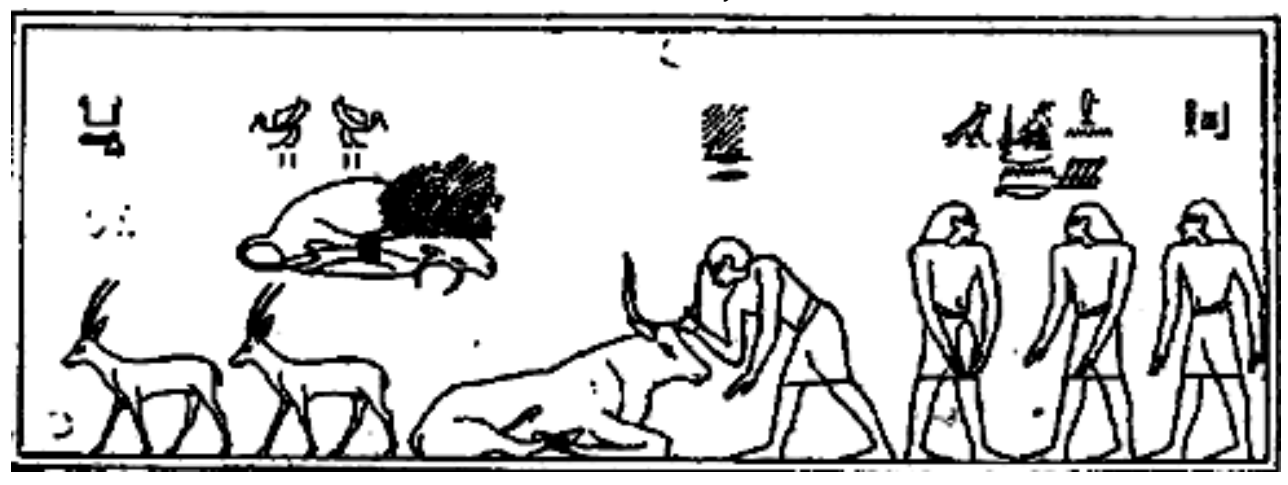

(ثكل · r) ذبح الثيران الحمراء- مقبرة مونتو -حر -خبش.إف - جبانة ذراع أبو النجا

MASPERO, Montouhikhopshouf, 461, FIG.10.

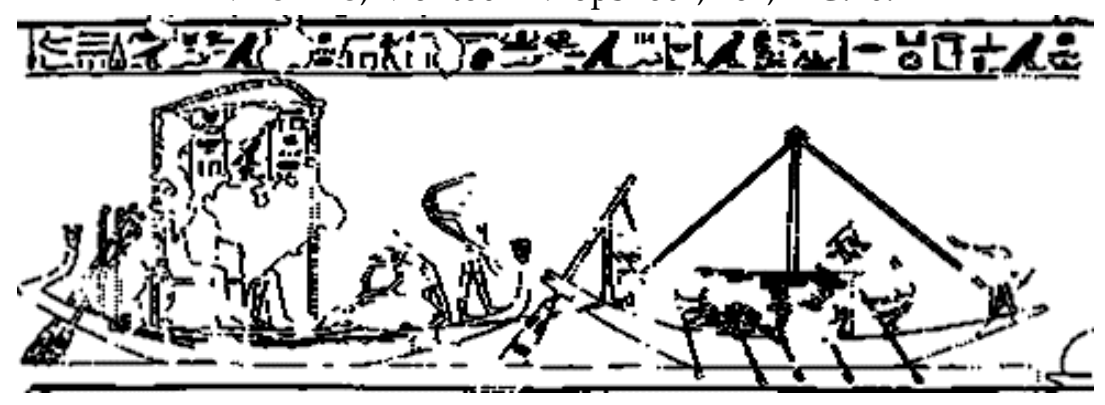

(شكل (ب) ذبح الثور الأحمر قربان لأوزير - مقبرة أمنمحات - جبانة شيخ عبد القرنة

DAVIES, The Tomb of Amenemhet, PL. XII. 